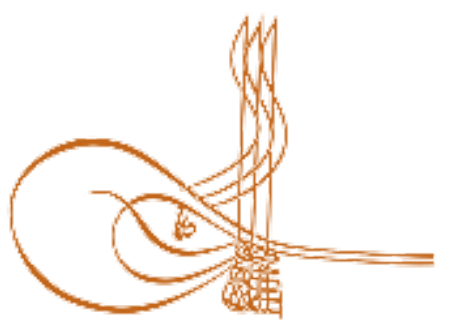

www.turkishstudies.net/turkishstudies
Turkish Studies

eISSN: $1308-2140$

Research Article / Araştırma Makalesi

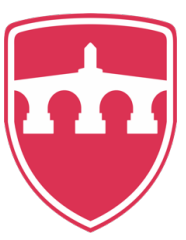

INTERNATIONAL

BALKAN

UNIVERSITY

Sponsored by IBU

\title{
Vatandaş İçin Medeni Bilgiler Kitabının 2018 Sosyal Bilgiler Öğretim Programında Yer Alan Değerler Açısından İncelenmesi
}

\author{
Study of The Book of Civil Information for the Citizens in Terms of Values 2018 Social Studies \\ Education Program
}

\author{
Vedat Karadeniz ${ }^{*}$ - Muhammet Fatih Kızılkaya ${ }^{* *}$
}

\begin{abstract}
Education is a tool that positively affects the value of individuals in social life by affecting their behaviours and attitudes from birth to death. The most important guiding resources in the shaping of education are teaching programs. In 2018, the Social Studies Education Program was published in a simple and comprehensible structure that aims to gain value and skills, taking individual differences into consideration. The curricula are prepared on the basis of "General Objectives of Turkish National Education" and "Basic Principles of Turkish National Education" which are stated in Article 2 of the Basic Law of National Education No. 1739. When we examine the Turkish history; From 1913 to 2018, we see a total of 22 programs implemented. This program which was published in a simple and comprehensible manner, takes individual differences into consideration, aiming at gaining value and skills. The aim of this study is to evaluate the book "Civil Knowledge for Citizens" within the framework of the values in the 2018 Social Studies curriculum. For this reason, the study was carried out with qualitative research traditions. The study was descriptive and an attempt was made to examine the existing situations. As the method of collecting information, the document analysis method used in the analysis of written sources was used and the data were tried to analyzed through text analysis. The study tried to examined "civil knowledge for citizens volume 1" by Ayșe Afet İnan, "Civil Knowledge for Citizens volume 2" by Recep Peker, the deputy of Kütahya, The Social Studies curriculum which was published and put into practice in 2018 and the 4th, 5th, 6th and 7th grade textbooks. In the first volume of the book, Civil Knowledge for Citizens, the concepts of nation, state and republic are defined and citizenship rights are emphasized. In the second volume of the book, functioning of the state administration structure of Turkish Republic, rights and duties of citizens in these organizations, how to use the rights they have, and how to fulfill their duties are explained. It is thought that both social studies curriculum and textbooks
\end{abstract}

\footnotetext{
* Doç. Dr., Erzincan Binali Yıldırım Üniversitesi, Eğitim Fakültesi, Türkçe ve Sosyal Bilimler Bölümü, Sosyal Bilgiler Eğitimi ABD.

Assoc. Prof., Erzincan Binali Ylldırım University, Faculty of Education, Turkish and Social Sciences Department, Social Studies Education.

ORCID 0000-0001-6667-3898

vkaradeniz25@gmail.com

** Doktora Öğrencisi, Erzincan Binali Yıldırım Üniversitesi, Sosyal Bilimler Enstitüsü.

PhD student, Erzincan Binali Yıldırım University, Social Sciences Institute.

ORCID 0000-0001-7143-279X

mfatihkizilkaya@gmail.com.
}

Cite as/ Atıf: Karadeniz, V. \& Kızılkaya, M. F. (2020). Vatandaş için medeni bilgiler kitabının 2018 sosyal bilgiler öğretim programında yer alan değerler açısından incelenmesi, Turkish Studies, 15(2), 923-961. https://dx.doi.org/10.29228/TurkishStudies.39729

Received/Geliş: 13 November/Kasım 2019

Accepted/Kabul: 29 April/Nisan 2020

Copyright $@$ MDE, Turkey 
as well as civil information books for the citizen are sufficient in transferring value. In terms of value transfer subjects, it can be said that the content of subjects included in social studies program and textbooks and Civil Knowledge for Citizen books overlap in terms of value transfer.

Structured Abstract: Values are a set of basic behaviors that guide us from past to present and teach us what to do. However, it is seen that value transfers started to take place in our curriculum after 2004. 18 values were included in the Social Studies curriculum updated in 2018. Undoubtedly, this is very important in terms of transferring values to younger generations. Because values are one of the main pillars that keep societies alive. In this study, Civil Information Books for Citizens, which are included in the formal education curriculum in the Republican period and have the characteristics of a Social Studies textbook, were tried to be examined according to 18 values in the Social Studies curriculum published in 2018. Of course, it is not correct to evaluate a historical work under today's conditions. It is believed that the Civil Information Books for Citizens, which are tried to be examined by considering the conditions of the period, contain very useful information as well as the concepts of value. This study was done with qualitative research traditions. The study is descriptive and an attempt was made to examine the existing situations. As the qualitative data collection method, the document analysis method used in the analysis of written sources was used and the data were tried to be analyzed through text analysis. In the research, the first volume of the book "Civil Information for Citizens" published in 1930 and the Social Studies curriculum and textbooks published in 2018 and the second part of the "Civil Information Book for Citizens" published in 1931 were used. In the first volume of the book Civil Information for Citizen, the concepts of nation, state and republic are defined and citizenship rights are emphasized. In the second volume of the state organization of the Republic of Turkey functioning of the structure, rights and duties of citizens in this organization, how to use these rights, and explain how they fulfil assignments.

In this study, They tried to carry out examinations on 18 values in the 2018 curriculum. These values are; justice is about caring for unity, independence, peace, scientificness, diligence, solidarity, sensitivity, honesty, aesthetics, equality, freedom, respect, love, responsibility, saving, patriotism and helpfulness.

What are the values in the 1 st and 2 nd volumes of the civil information book for the citizen and in the Social Studies Curriculum? Are the values included in the Social Studies Curriculum in 1st and 2nd volumes of the Civil Information Book for Citizens and Citizens included? The findings of the examination Were based on the questions that are briefly stated below.

When 2018 social studies curriculum and textbooks are examined, it is thought that the value of justice is transferred in 5 learning areas. When the civil information books for the citizen are examined, it is believed that the book tries to transfer over 7 topics in the first volume and 3 topics in the second volume.

When the 2018 social studies curriculum and textbooks were examined, it is thought that the Importance of Family Unity is tried to be transferred in 2 learning areas. When the civil information books for the citizen have been examined, it is thought that they tried to transfer over 1 subject in the first and second volumes of the book.

When the 2018 social studies curriculum and textbooks are examined, it is thought that the value of Independence is tried to be transferred in 1 learning area. When the civil information books for the citizen are examined, it is believed that the book tries to transfer over 4 topics in the first volume and 2 topics in the second volume.

When 2018 social studies curriculum and textbooks are examined, it is thought that the value of Peace is tried to be transferred in 3 learning areas. When the civil information books for the citizen are examined, it is believed that they tried to transfer over 2 topics in the first and second volumes of the book.

When the 2018 social studies curriculum and textbooks are examined, it is thought that the value of Scientificity is tried to be transferred in 3 learning areas. When the civil information books for the citizen are examined, it is believed that they tried to transfer over 2 topics in the first and second volumes of the book.

When 2018 social studies curriculum and textbooks are examined, it is thought that the Diligence value is tried to be transferred in 4 learning areas. When the civil information books for the citizen are examined, it is thought that they tried to transfer over 5 topics in the first volüme and 2 topics in the second volume. 
When 2018 social studies curriculum and textbooks are examined, it is thought that the value of Solidarity is tried to be transferred in 5 learning areas. When the civil information books for the citizen are examined, it is thought that the book tries to transfer over 4 topics in the first volume and 1 topic in the second volume.

When the 2018 social studies curriculum and textbooks are examined, it is thought that the Sensitivity value is tried to be transferred in 7 learning areas. When the civil information books for the citizen are examined, It was not mentioned in the first volume but the second volume where it tried to transfer over 2 topics.

When 2018 social studies curriculum and textbooks are examined, it is thought that the value of Integrity is tried to be transferred in 3 learning areas. When the civil information books for the citizen are examined, It was transferred on the 2 nd and 2 nd volumes of the book on 2 topics.

When the 2018 social studies curriculum and textbooks are examined, it is thought that the Aesthetic value is tried to be transferred in 3 learning areas. When the civil information books for the citizen are examined, it is believed that the book tried to transfer it on 1 and 2 volumes.

When 2018 social studies curriculum and textbooks are examined, it is tried to transfer the value of Equality in 3 learning areas. When the civil information books for the citizen are examined, it is the book. In the first volume, it is thought that it is tried to transfer over 6 topics. In the second volume, it was not mentioned.

When the 2018 social studies curriculum and textbooks are examined, it is thought that the value of Liberty is tried to be transferred in 6 learning areas. When the civil information books for the citizen are examined, it is the book. In the first volume, it is thought that it is tried to transfer over 4 topics. In the second volume, it was not mentioned.

When the 2018 social studies curriculum and textbooks are examined, it is thought that the value of Respect is tried to be transferred in 4 learning areas. When the civil information books for the citizen are examined, it is believed that the book tries to transfer over 7 topics in the first volume and 5 topics in the second volume.

When the 2018 social studies curriculum and textbooks are examined, it is thought that the value of Love is tried to be transferred in 4 learning areas. When the civil information books for the citizen are examined, it is thought that They tried to transfer 3 topics in the first and second volumes of the book.

When 2018 social studies curriculum and textbooks are examined, it is thought that the responsibility value is tried to be transferred in 3 learning areas. When the civil information books for the citizen are examined, it is believed that the book tries to transfer over 7 topics in the first volüme and 4 topics in the second volume.

When 2018 social studies curriculum and textbooks are examined, it is thought that Saving value is tried to be transferred in 3 learning areas. When the civil information books for the citizen are examined, it is thought that the book tries to transfer over 2 topics in the first volume and 1 topic in the second volume.

When the 2018 social studies curriculum and textbooks are examined, it is thought that patriotism value is tried to be transferred in 4 learning areas. When the civil information books for the citizen are examined, it is thought that the book Tries to transfer over 2 topics in the first volume and 3 topics in the second volume.

When the 2018 social studies curriculum and textbooks are examined, it is thought that the value of philanthropy is tried to be transferred in 2 learning areas. When the civil information books for the citizen are examined, it is thought that the book tries to transfer 1 subject in the first volume and 2 topics in the second volume.

What are the values included in the first and second volumes of the civil information book for the citizen but not in the Social Studies Curriculum?

In the 1st and 2nd volumes of the Civil Information Book for the Citizen, there is Mercy, Sacrifice and Trust value. For mercy value; It is believed that the first volume Tries to transfer over 1 subject. The value of sacrifice; It is thought that in the first volume, tries to transferover 3 topics. The value of trust; It is believed that the first volume Tries to transfer over 1 subject. 


\section{Conclusion and Discussion}

According to the results of the examination made on the learning area: In the field of individual and society learning; it is believed that values of justice, family unity, scientificness, diligence, solidarity, sensitivity, aesthetics, freedom, respect, love, responsibility, patriotism and benevolence are tried to be transferred, and among these values, love and responsibility values are given more with 5 issues. The reason why these two values are given too much may be because the two values play a leading role in the realization of the individual. In addition, it is thought that the values of independence, peace, honesty, equality and savings are not transferred in this learning field. The main reason for this is that in the social studies curriculum, this learning area focuses on psychology, sociology and social psychology from the social sciences, which includes the processes of being "I" and "we", as well as an interdisciplinary approach. In this context, it is thought that 13 values are tried to be transferred sufficiently in the process of being "me" and "us".

The first and second volumes of civil information books for the citizen were examined on the basis of values and as a result: in the first volume; justice, independence, peace, scientificness, diligence, solidarity, honesty, aesthetics, equality, freedom, respect, love, responsibility, savings, patriotism and benevolence are considered. It is thought that the importance of giving importance to family unity and sensitivity are not included. In the second volume; values of justice, family unity, independence, peace, scientificness, diligence, solidarity, sensitivity, honesty, aesthetics, respect, love, responsibility, saving, patriotism and benevolence are considered. It is thought that equality and freedom values are not included. In addition, the first volume includes Mercy, Sacrifice and Trust.

As a result; It is considered that both social studies curriculum and textbooks and civil information books for citizens are at a sufficient level in terms of value transfer. In terms of value transfer issues, it can be said that the content of subjects in the social studies program and textbooks and civil information books overlap in terms of value transfer.

It is recommended to review the text of the 2018 Social Studies curriculum in terms of content suitability for textbooks and value promotion.

Keywords: Social Studies, Education, Value, Curriculum, Textbook.

Öz: Eğitim bireylerin doğumundan ölümüne kadar hal ve hareketlerini etkileyerek sosyal yaşam içerisindeki değerini olumlu yönde etkileyen bir araçtır. Eğitimin şekillenmesinde en önemli yol gösterici kaynaklar da öğretim programlarıdır. 2018 yılında bireysel farklılıkları dikkate alan, değer ve beceri kazandırma hedefli, sade ve anlaşılır bir yapıda Sosyal Bilgiler Öğretim Programı yayımlanmıştır. Öğretim programları, 1739 sayılı Millı̂ Eğitim Temel Kanununun 2. maddesinde ifade edilen "Türk Millî Eğitiminin Genel Amaçları" ile "Türk Millî Eğitiminin Temel İlkeleri" esas alınarak hazırlanmaktadır. Türk tarihini incelediğimizde; 1913 yılından 2018 y1lına kadar toplam 22 programın hayata geçirildiğini görmekteyiz. Yayımlanan bu program: bireysel farklılıkları dikkate alan, değer ve beceri kazandırma hedefli, sade ve anlaşılır bir yapıdadır. Bu çalışmanın amacı "Vatandaş İ̧̧in Medeni Bilgiler" kitaplarını 2018 Sosyal Bilgiler öğretim programında yer alan değerler çerçevesinde değerlendirmektir. $\mathrm{Bu}$ nedenle çalışma nitel araştırma gelenekleriyle yapılmıştır. Çalışma betimsel nitelikte olup var olan durumlar üzerinden inceleme gerçekleştirilmeye çalışılmıştır. Nitel veri toplama yöntemi olarak yazılı kaynakların analizinde kullanılan doküman inceleme yöntemi kullanılmış ve veriler metin analizi yoluyla irdelenmeye çalışılmıştır. Araştırmada Ayşe Afet İnan tarafından yazılan "Vatandaş İ̧̧in Medeni Bilgiler Cilt 1" kitabı ile Kütahya mebusu Recep Peker tarafından yazılan "Vatandaş

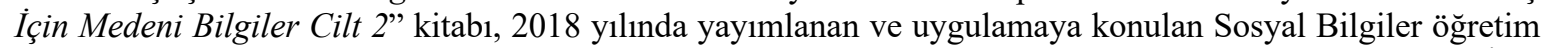
programı ve 4.,5.,6. ve 7.sınıf ders kitapları incelenmeye çalışılmıştır. Kaynak olarak incelenen Vatandaş İçin Medeni Bilgiler kitabının birinci cildinde millet, devlet ve Cumhuriyet kavramlarının tanımı yapılmakta ve vatandaşlık hakları üzerinde durulmaktadır. İkinci ciltte ise Türkiye Cumhuriyeti'nin devlet teşkilat yapısının işleyişi, vatandaşların bu teşkilat içindeki hak ve ödevleri, sahip oldukları haklarını nasıl kullanacakları, ödevleri nasıl yerine getirecekleri anlatılmıștır. Hem sosyal bilgiler öğretim programı ile ders kitapları hem de vatandaş için medeni bilgiler kitaplarının değer aktarımı konusunda yeterli düzeyde oldukları düşünülmektedir. Değer aktarım konuları açısından sosyal bilgiler programı ve ders kitaplarında yer alan konu içerikleri ile Vatandaş İçin Medeni Bilgiler kitaplarının değer aktarım açısından örtüştüğü söylenilebilir.

Anahtar Kelimeler: Sosyal Bilgiler, Eğitim, Değer, Öğretim Programı, Ders Kitabı. 


\section{Giriş}

Geçmişten günümüze eğitimi şekillendiren en önemli yol gösterici kaynak öğretim programlarıdır. Öğretim programları: belli bir öğretim basamağında bulunan çeşitli sınıflarda ve derslerde okutulmak istenen konuları; bu konuların amaçlarını, ders ve sınıfa göre haftada kaç saat okutulacağını ve öğretim yöntemlerini gösteren kılavuzdur (Büyükkaragöz ve Çivi, 1999). Türk tarihini incelediğimizde 1913 yılından 2018 yılına kadar toplam 22 programın hayata geçirildiğini görmekteyiz. Elbette bu programlar eğitimin şekillenmesinde önemli bir yere sahiptir. Öğretim programları, 1739 sayılı Millî Eğitim Temel Kanunu'nun 2. maddesinde ifade edilen "Türk Millî Eğitiminin Genel Amaçları" ile "Türk Millî Eğitiminin Temel İlkeleri" esas alınarak hazırlanmaktadır (MEB, 2018). Eğitim ve öğretim programlarıyla sürdürülen bütün çalışmalar (okul öncesi, ilköğretim ve ortaöğretim düzeyinde) birbirlerini tamamlayıc1 niteliktedir. 2018'de yayımlanan yeni Sosyal Bilgiler öğretim programı ise salt bilgi aktaran bir yapıdan ziyade bireysel farklılıkları dikkate alan, değer ve beceri kazandırma hedefli, sade ve anlaşılır bir yapıda hazırlanmıştır (MEB, 2018).

Eğitim sistemimizin esas amacı değerler ve yetkinliklerle bütünleşmiş bilgi, beceri ve davranışlara sahip bireyler yetiştirmektir. Bilgi, beceri ve davranışlar öğretim programlarıyla öğrencilere verilmeye çalışılırken değerlerimizde bu bilgi, beceri ve davranışların arasındaki bağı kuran bir işlev görmektedir. Değerlerimiz öğretim programlarının görünüşünü oluşturan prensiplerin toplamıdır (MEB, 2018). Eğitim programlarında üzerinde durulmakla birlikte değerler; alan sınırlaması aranmaksızın, öğretmenlerin sınıf içindeki öğrenme ortamlarını düzenlemede, sınıf içi etkinlikleri uygulamada, öğretim stratejisi belirlemede, konu seçiminde kısaca öğrencilere yönelik tutum ve davranışlarda yer almalıdır (Veugelers ve Vedder, 2003).

Öğretim programları, insan gelişiminin belirli bir dönemde sonlanmadığı ve bu gelişimin ömür boyu sürdüğü ilkesi ile hazırlanmaktadır. Hazırlanan öğretim programlarının uygulanmaya çalışıldığı yer ise okullardır. Değere dayalı örgütler arasında yer alan okul, içinde bulunduğu toplumun önemli bir öğesi olup, okuldaki yapı toplumların sahip olduğu inanç ve ilkelerin yönünü belirler (Ryan ve E. Bohlin, 1999). Bu bakımdan insan ilişkilerinin önemini vurgulayan değerlerin öncelikli olarak okullarda algılanması beklenir (Sağnak, 2004). Değerler eğitimi de vatandaş yetiştirme sürecinde okulda gerçekleşmektedir. Bu dönemde öğretmenler bilinçli ya da bilinçsiz bir şekilde, değerleri öğrencilere aktarırlar (Coombs-Richardson ve Toison, 2005). Öğrenciler de değerleri oluşturma konusunda öğretmenlerin, ebeveynlerin ve medyanın etkisi altındadırlar (Harris, 1991). Değerler aynı zamanda devleti, okulu, verimliliği ve sosyal huzuru da etkilemektedir (Tatto vd., 2001).

Eğitimdeki genel hedefler ülkelerin veya içinde bulunulan toplumların geleceklerini şekillendirmektedir. Toplumların geleceklerini şekillendiren hedeflerin değerlerden bağımsız olması düşünülemez. $\mathrm{Bu}$ nedenle ülkenin veya toplumun eğitim sisteminde genel hedefler ortaya konulduğunda o toplumun eğitiminin değerleri de ortaya konulmuş olacaktır (Bayramoğlu, 2016). Hedefler toplumların önemsedikleri ve ulaşmak istedikleri nihai sonuçlar olarak nitelenebileceğinden bir toplumun hedefleri aynı zamanda değerlerini de gösterecektir. Toplumlar geçmişten günümüze kadar sahip oldukları değerleri gelecek nesillere aktarma gayreti içinde olmuşlardır (Nalçacı, 2016). Çünkü toplumların geleceği iyi eğitim görmüş, düşünce ve hareketleri tutarlı, sağlam karakterli bireylere bağlıdır (Ekşi, 2003). İnsanlar değer yargılarına göre düşünür ve ona göre hareket ederler. Bireyin değer sisteminin gelişimi ailede başlar ancak sosyal hayatının büyük bir devresini oluşturan okul bu gelişimde çok büyük bir öneme sahiptir. Bazı değerlerin öğretiminde okulun işlevi aileye göre daha fazladır (Ulusoy, 2007).

Toplumlar kendilerine özgü amaçlara ulaşmak için belirlenen hedefe göre bir değer sistemi oluşturmaktadır. Hedef kalkınmaysa kalkınmaya, çağdaş medeniyet ise çağdaş medeniyet seviyesine ulaşabilmek için uygun değerler geliştirilmelidir (Güngör, 1998). Bu çerçevede 1930'lu yılların, 
rejime uygun vatandaş yetiştirme görevinin Cumhuriyet pedagogları tarafından ele alındığı bir dönem olduğu görülmektedir. Bu nedenle Mustafa Kemal Atatürk özellikle tarih ve yurttaşlık bilgisi dersinin öğretimiyle yakından ilgilenmiştir (Gürses, 2010).

Cumhuriyetin ilanından sonra vatan ve millet sevgisinin yanı sıra demokratik değerleri de benimsetme amacıyla yazımında bizzat yer aldığı ve Ayşe Afet İnan tarafindan 1930 yılında basılan "Vatandaş İçin Medeni Bilgiler (cilt 1)" kitabı Atatürk'ün yurttaş eğitimine verdiği önemin bir göstergesidir. Bu ders kitabı, Cumhuriyet'in kuruluşunda temel felsefeyi belirleme açısından önemli bir eserdir. Bu eserin 2. cildi ise Kütahya mebusu Recep Peker tarafından 1931 yılında yazılmıştır. Günümüzde okutulan Sosyal Bilgiler ders kitapları gibi 2 ciltlik bu eser dönemin değerlerini benimsetme açısından önemli bir yere sahiptir. Bu nedenle Cumhuriyetin ilanından sonra hazırlanan bu kitapların 2018 yılında yayımlanan Sosyal Bilgiler programına göre değerlendirmesi elbette değer sisteminin gelişimini görmek açısından oldukça önemlidir.

\section{Yöntem ve Amaç}

$\mathrm{Bu}$ çalışma nitel araştırma gelenekleriyle yapılmıştır. Çalışma betimsel nitelikte olup var olan durumlar üzerinden inceleme gerçekleştirilmeye çalışılmıştır. Nitel araştırma gözlem, görüşme ve doküman incelemesi gibi nitel veri toplama yöntemlerinin kullanıldığı, algıların ve olayların doğal ortamda gerçekçi ve bütüncül bir biçimde ortaya koyulmasına yönelik nitel bir sürecin izlendiği araştırma olarak tanımlanabilir (Yıldırım \& Şimşek, 2011). Nitel veri toplama yöntemi olarak yazılı kaynakların analizinde kullanılan doküman inceleme yöntemi kullanılmış ve veriler metin analizi yoluyla irdelenmeye çalışılmıştır. Doküman inceleme yöntemi; doküman incelemesi, araştırılması hedeflenen olgu veya olgular hakkında bilgi içeren yazılı materyallerin analizini kapsamaktadır. Nitel araştırmada doküman incelemesi tek başına bir veri toplama yöntemi olabileceği gibi diğer veri toplama yöntemleri ile birlikte de kullanılabilir (Yıldırım ve Şimşek, 2011).

$\mathrm{Bu}$ çalışmanın amacı "Vatandaş İçin Medeni Bilgiler" kitaplarını 2018 Sosyal Bilgiler öğretim programında yer alan değerler çerçevesinde değerlendirmektir. Yapılan bu çalışmada;

Vatandaş için medeni bilgiler kitabının 1. ve 2. cildinde Sosyal bilgiler Öğretim Programında yer alan değerlere yer verilmiş midir?

Vatandaş için medeni bilgiler kitabının 1. ve 2. cildinde yer verilen ancak Sosyal bilgiler Öğretim Programında yer verilmeyen değerler hangileridir? sorularına cevaplar aranmaya çalışılmıştır.

Araştırmada veri toplama aracı olarak 1930 yılında basılan "Vatandaş İçin Medeni Bilgiler" kitabının 1. cildi ve 1931 yılında basılan "Vatandaş İçin Medeni Bilgiler kitabının 2. cildi ile 2018 yılında yayımlanan Sosyal Bilgiler öğretim programı ve ders kitapları kullanılmıştır. Vatandaş İçin Medeni Bilgiler kitabı, 1931 yılında iki cilt halinde yayımlanmıştır. Mustafa Kemal Atatürk Cumhurbaşkanı sıfatıyla, 18.09.1931 tarihinde İsmet Paşa'ya resmi bir yazı göndererek bu kitabın basımını istemiştir. Bu yazıda yurt bilgisinin önemi, seçim, askerlik ve vergi konularının yeniden basımı için tavsiyede bulunulmuştur. Kitabın ikinci cildinin devlet teşkilatı Türkiye Büyük Millet Meclisinin, hükûmetin, özel idarelerin, belediyelerin işleyişi konularından oluştuğu ve her iki kitabında maarif vekaletince tespit edilen okullarda okutulmak üzere ders programlara eklenmesi istenmiştir. Ayrıca belirlenen sınıfların üstündeki öğrencilere de mezun olmadan okutulması gerektiği hususunda görüş bildirilmiştir.

Vatandaş İçin Medeni Bilgiler kitabının 1.cildi Afet İnan adıyla, 2.cildi ise Kütahya Mebusu Recep Peker adıyla yayınlanmıştır. Birinci ciltte millet, devlet ve Cumhuriyet kavramlarının tanımı yapılmakta ve vatandaşlık hakları üzerinde durulmaktadır. İkinci ciltte ise Türkiye Cumhuriyeti'nin devlet teşkilat yapısının işleyişi, vatandaşların bu teşkilat içinde hak ve ödevleri, bu haklarını nasıl kullanacakları, ödevleri nasıl yerine getirecekleri anlatılmıştır (Gürses, 2010). 
Bu çalışma, Vatandaş İçin Medeni Bilgiler kitapları ile güncel sosyal bilgiler ders kitapları değer kavramları dikkate alınarak metin analizi yoluyla incelenmeye çalışılmıştır. Kitaplardaki bölüm, öğrenme alanı ve konu içerikleri okunarak içerisinde değer aktarıldığ 1 düşünülen cümle örnekleri belirlenmiştir. Cümle örnekleri 2018 sosyal bilgiler öğretim programında yer alan kazanımlarla bağdaştırılarak değerlerin aktarılıp aktarılmadığı yorumlanmaya çalışılmıştır.

\section{Bulgular}

$\mathrm{Bu}$ bölümde 2018 Sosyal Bilgiler Öğretim Programında yer alan değerlerin öğrenme alanlarına göre sınıflandırılmasına ve Vatandaş İçin Medeni Bilgiler kitabının 1. ve 2. Cildi ile sosyal bilgiler kitaplarında değer kavramlarını barındıran başlıklara, kazanımlara ve cümle örneklerine yer verilmiştir.

Tablo 1: 2018 Sosyal Bilgiler Öğretim Programında Yer Alan Değerler

\begin{tabular}{|l|l|l|l|c|l|}
\hline $\mathbf{1}$ & Adalet & $\mathbf{7}$ & Dayanışma & $\mathbf{1 3}$ & Sorumluluk \\
\hline $\mathbf{2}$ & Aile birliğine önem verme & $\mathbf{8}$ & Estetik & $\mathbf{1 4}$ & Tasarruf \\
\hline $\mathbf{3}$ & Bağımsızlık & $\mathbf{9}$ & Eşitlik & $\mathbf{1 5}$ & Duyarlıı \\
\hline $\mathbf{4}$ & Barı̧̧ & $\mathbf{1 0}$ & Özgürlük & $\mathbf{1 6}$ & Dürüstlük \\
\hline $\mathbf{5}$ & Bilimsellik & $\mathbf{1 1}$ & Saygı & $\mathbf{1 7}$ & Vatanseverlik \\
\hline $\mathbf{6}$ & Çalışkanlık & $\mathbf{1 2}$ & Sevgi & $\mathbf{1 8}$ & Yardımseverlik \\
\hline
\end{tabular}

Tablo 1 de görüldüğg̈ üzere 2018 öğretim programında toplam 18 değere yer verilmiştir. Bu değerler; adalet, aile birliğine önem verme, bağımsızlık, barış, bilimsellik, çalışkanlık, dayanışma, duyarlılık, dürüstlük, estetik, eşitlik, özgürlük, saygı, sevgi, sorumluluk, tasarruf, vatanseverlik ve yardımseverliktir.

\section{Vatandaş için medeni bilgiler kitabının 1. ve 2.cildinde Sosyal bilgiler Öğretim Programında yer alan değerlere yer verilmiș midir?}

\section{Adalet Değeri:}

Tablo 2: 2018 Sosyal Bilgiler Öğretim Programı ile Vatandaş İçin Medeni Bilgiler Kitabının 1. ve 2. Cildinde Adalet Değerinin Kazandırıldığı Konuların Dağılımları

\begin{tabular}{|c|c|c|c|c|}
\hline $\begin{array}{l}\text { ÖĞRENME } \\
\text { ALANLARI }\end{array}$ & SINIFLAR & $\begin{array}{ll}\text { ADALET } & \text { DEĞERININ } \\
\text { KAZANDIRILDIĞI KONULAR }\end{array}$ & $\begin{array}{l}\text { CILT } 1 \text { KONU } \\
\text { BAȘLIKLARI }\end{array}$ & $\begin{array}{l}\text { CIILT } 2 \text { KONU } \\
\text { BAȘLIKLARI }\end{array}$ \\
\hline Birey ve Toplum & 6. Sinıf & $\begin{array}{lll}\text { Kültürümüzle } & \text { Yaşıyor } & \text { ve } \\
\text { Gelișiyoruz } & & \end{array}$ & $\begin{array}{l}\text { Demokrasi } \\
\text { Prensipinin }\end{array}$ & \\
\hline \multirow{4}{*}{ Kültür ve Miras } & 6. Sinif & Destan ve Yazıtlarda Türkler & Vasıfları & \\
\hline & 6. Sinif & İslamiyet'in Doğuşu ve Değişim & Hak İle Vazifenin & \\
\hline & 6. Sinif & Yeni Yurt Anadolu & Münasebeti & \\
\hline & 7. Sinif & İnsanı Yaşat Ki Devlet Yaşasın & Vatandasa Kars1 & \\
\hline $\begin{array}{lll}\text { Bilim, } & \text { Teknoloji } & \text { ve } \\
\text { Toplum } & & \end{array}$ & 7. Sinif & Özgür Düşüncenin Bilime Katkısı & $\begin{array}{l}\text { Vatandaşa Karşı } \\
\text { Devletin Vazifeleri }\end{array}$ & \multirow{2}{*}{ Adliye - Vazife } \\
\hline $\begin{array}{l}\text { Üretim, Dağıtım ve } \\
\text { Tüketim }\end{array}$ & 4. Sinif & Bilinçli Tüketici Olalım & Kadınların İntihap & \\
\hline \multirow{6}{*}{ Etkin Vatandaşlık } & 5. Sinif & Halka Hizmet Veren Kurumlar & & \multirow{6}{*}{$\begin{array}{l}\text { Mahkemeler } \\
\text { Hâkim }\end{array}$} \\
\hline & 5. Sinif & Temel Haklarımız & & \\
\hline & 6. Sinif & Hayatın İçinde Demokrasi & Vergi Kaideleri & \\
\hline & 6. Sinif & Kadın ve Toplum & \multirow{3}{*}{$\begin{array}{l}\text { Tek Vergi Ve Çok } \\
\text { Vergiler }\end{array}$} & \\
\hline & 7. Sinif & Demokrasi Serüveni & & \\
\hline & 7. Sinif & Cumhuriyetimi Seviyorum & & \\
\hline
\end{tabular}

Tablo 2 incelendiğinde Adalet değerinin; Birey ve Toplum, Kültür ve Miras, Bilim, Teknoloji ve Toplum, Üretim, Dağıtım ve Tüketim ile Etkin Vatandaşlık öğrenme alanlarında aktarılmaya çalışıldığı düşünülmektedir.

Birey ve Toplum öğrenme alanında 6.sınıf konusu olan Kültürümüzle Yaşıyor ve Gelişiyoruz başlı̆̆ altında "sosyal, kültürel ve tarihî bağların toplumsal birlikteliğin oluşmasındaki 
yerini ve rolünü analiz eder" kazanımı üzerinden değerin aktarılmaya çalışıldığı düşünülmektedir. Başlık altında yer alan konu anlatım metninde; millet olarak tarih boyunca inancımızın ve kültürümüzün temel unsurları olan insan sevgisi, yardımlaşma ve adaleti yaşatmaya çalıştığımız vurgulanarak adalet kavramı üzerinden değerin doğrudan aktarılmaya çalışıldığı düşünülmektedir.

Kültür ve Miras öğrenme alanında 6.sınıfta Destan ve Yazıtlarda Türkler başlığı altında "Orta Asya'da kurulan ilk Türk devletlerinin coğrafi, siyasal, ekonomik ve kültürel özelliklerine ilişskin çıkarımlarda bulunur. ” kazanımı üzerinden değerin aktarılmaya çalışıldığı düşünülmektedir. Başlık altında yer alan Gök Tanrı inancını yansıtan metninde; Kök Türk Yazıtlarında töresini kaybetmiş ulusun yok olacağı hatırlatılarak kağanlardan töreye uygun davranmaları istenmiş ve törenin değişmeyen hükümlerinin adalet, iyilik ve eşitlik olduğu belirtilerek değerin doğrudan aktarılmaya çalışıldığı düşünülmektedir. 6.sınıfta İslamiyet'in Doğuşu ve Değişim başlığı altında "Islamiyet'in ortaya çıkışını ve beraberinde getirdiği değişimleri yorumlar." kazanımı üzerinden değerin aktarılmaya çalışıldığı düşünülmektedir. Bu konu içerisinde yer alan anlatım metninde; $\mathrm{Hz}$. Peygamberin sohbetine katılıp ona inanan sahabe adı verilen kişilerin müslüman olmalarında yeni dinin; zulme, adaletsizliğe, haksızlığa ve akla gelebilecek her türlü kötülüğe karşı durmasının etkili olduğunu aktaran cümle ile Hz. Peygamberin Müslüman, Yahudi ve Medineli putperestleri bir araya getirerek Medine Sözleşmesi'ni yaptığı ve bu sözleşmenin, ahlak ve adalet ilkeleri açısından oldukça önemli olduğunu belirten cümle üzerinden değerin doğrudan aktarılmaya çalışıldığ 1 düşünülmektedir. 6.sınıfın başka bir konusu olan Yeni Yurt Anadolu başlığı altında da "Türklerin Anadolu'yu yurt edinme sürecini XI ve XIII. yüzyıllar kapsamında analiz eder." kazanımı üzerinden değerin aktarılmaya çalışıldığı düşünülmektedir. Türkiye Selçuklu Devleti anlatılırken Bizans'ın zayıflıklarından yararlanan Süleyman Şah'ın, İznik'e kadar geldiği ve burayı başkent yaparak Türkiye Selçuklu Devleti'ni kurduğu anlatılırken, fethettiği yerlerdeki halka adaletle davranması müslüman olmayan halkın da devlete bağlılığını artırdığını belirten cümle yoluyla değerin aktarılmaya çalışıldığ düşünülmektedir. 7.sınıf konusu olan İnsanı Yaşat Ki Devlet Yaşasın başlığ1 altında da "Osmanlı Devleti'nin fetih siyasetini örnekler üzerinden analiz eder" ve "Gaza ve cihat anlayışı, istimâlet politikası, millet sistemi üzerinde durulur." kazanımları üzerinden değerin aktarılmaya çalışıldığı düşünülmektedir. Konu içerisinde aktarılan Şeyh Edebali'nin Osman Gazi'ye nasihati üzerinden; "Ey oğul, artık beysin! Bundan sonra öfke bize, uysallık sana. Güceniklik bize, gönül almak sana. Suçlamak bize, katlanmak sana. Acizlik bize, hoş görmek sana. Çatışmalar, anlaşmazlıklar bize, adalet sana. Kötü söz, şom ağız, haksız yorum bize, bağışlamak sana. Bölmek bize bütünlemek sana..." cümleleriyle değerin aktarılmaya çalış1ldığı düşünülmektedir.

Bilim, teknoloji ve toplum öğrenme alanında 7.sınıf konusu olan Özgür Düşüncenin Bilime Katkısı başlığı altında “Özgür düşüncenin bilimsel gelişmelere katkısını değerlendirir." kazanımı üzerinden değerin aktarılmaya çalışıldığı düşünülmektedir. Konu içerisinde yer alan Rönesans ve reform hareketleri sonucunda 1789 yılında Fransız düşünürlerin de etkisiyle meydana gelen Fransız İhtilali ile Fransa'nın yönetim biçiminin değiştiği ve tüm dünyaya yayılan "hürriyet, adalet, kardeşlik, eşitlik" gibi kavramların özgür düşüncenin gelişmesine katkı sağladığını belirten cümle ile değerin doğrudan aktarılmaya çalışıldığı düşünülmektedir.

Üretim, Dağıtım ve Tüketim öğrenme alanında 4.sınıf konusu olan Belgemizi Alalım başlığı altında "Sorumluluk sahibi bir birey olarak bilinçli tüketici davranışları sergiler." kazanımı üzerinden değerin aktarılmaya çalışıldığı düşünülmektedir. Başlık altında yer alan konu anlatım metninde; alışveriş sonrasında alacağımız belgenin üzerindeki miktarın yazar kasa aracılığıyla kayıtlara geçeceği ve devletin bu kayıtlar üzerinden vergi topladığı aktarılmaktadır. Fiş veya fatura alınmadığında ise satış işlemi kayıtlara geçmeyeceği bu durum sonucunda da devlete ödenmesi gereken paranın satıcının kasasında kalması ve vergi gelirlerinin azalması anlamına geldiğini aktaran cümlelerle adalet değerin dolaylı olarak aktarılmaya çalışıldığı düşünülmektedir. 
Etkin Vatandaşlık öğrenme alanı içerisinde 5.sınıf konularından Halka Hizmet Veren Kurumlar başlığı altında "Bireysel ve toplumsal ihtiyaçlar ile bu ihtiyaçların karşılanması için hizmet veren kurumları ilişkilendirir." kazanımı üzerinden değerin aktarılmaya çalışıldığı düşünülmektedir. Kurumlar anlatılırken; "Yargıtay, Danıştay, Adliyeler, cezaevleri, Adli Tip Kurumu ve barolar adalet ihtiyacımızı karşılayan kurumlara örnektir." ve "Bu kurumlar T.C. Adalet Bakanlığına bağlıdır." cümleleriyle değerin aktarılmaya çalışıldığı düşünülmektedir. 5.sınıfın diğer konusu Temel Haklarımız başlığı altında "Temel hakları ve bu hakları kullanmanın önemini açıklar" ve "Temel haklardan katılım ve düşüne özgürlüğ̈̈ hakkı üzerinde durulur." kazanımları üzerinden değerin aktarılmaya çalışıldığı düşünülmektedir. Konu içerisinde temel hak ve özgürlüklerin korunduğu ve kullanıldığı bir toplumun bireylerinin huzur ve güven içinde yaşadığı ve bu tür toplumlarda adalet ve eșitliğin insanlar arasında daha kolay sağlandı ̆̆ belirtilerek değerin doğrudan aktarılmaya çalışıldığ1 düşünülmektedir. 6.sınıfta Hayatın İçinde Demokrasi başlığı altında “Toplumsal hayatımızda demokrasinin önemini açıklar." kazanımı üzerinden değerin aktarılmaya çalışıldığ düşünülmektedir. Konu metni içerisinde Türklerin adaletli ve insaniyetli yaklaşımını gören farklı milletlerin, Türk devletleri ve beyliklerinin toplum hayatını düzenleyen hukuk kurallarına uymak zorunda oldukları belirtilerek, insanların hukuk sistemi içinde yasalara uygun bir hayat yaşamaları söz konusu olunca hak, özgürlük, eşitlik ve adalet kavramlarının ön plana çıkacağını aktaran cümleler ile değerin aktarılmaya çalışıldığı düşünülmektedir. 6.sınıfın başka bir konusu olan Kadın ve Toplum başlı̆̆ altında da "Türk tarihinden ve güncel örneklerden yola çıkarak toplumsal hayatta kadına verilen değeri fark eder." kazanımı üzerinden değerin aktarılmaya çalışıldığ 1 düşünülmektedir. Konu anlatımı metninde toplumsal alanda cinsiyet eşitliğinin kadın ve erkek arasında adaletin ve hakkaniyetin sağlanması ile gerçekleşebileceği belirtilerek değerin aktarılmaya çalıșı1dığ düşünülmektedir. 7.sınıfta Demokrasi Serüveni başlığı altında "Demokrasinin ortaya çıkışını, gelişim evrelerini ve günümüzde ifade ettiği anlamları açıklar. " kazanımı üzerinden değerin aktarılmaya çalışıldığı düşünülmektedir. Konu anlatım metni içerisinde Bilge kağan yazıtından örnek gösterilerek eski Türk devletlerinde adaletin bir devlet töresi olduğu belirtilerek değerin aktarılmaya çalışıldığı düşünülmektedir. 7. sınıfın diğer bir konusu olan Cumhuriyetimi Seviyorum başlığı altında da "Türkiye Cumhuriyeti Devleti'nin temel niteliklerini toplumsal hayattaki uygulamalarla ilişkilendirir." kazanımı üzerinden değerin aktarılmaya çalışıldığı düşünülmektedir. Konu anlatım metni içerisinde anayasanın ikinci maddesine yer verilerek "Türkiye Cumhuriyeti, toplumun huzuru, millî dayanışma ve adalet anlayışı içinde, insan haklarına saygıll, Atatürk milliyetçiliğine bağll, başlangıçta belirtilen temel ilkelere dayanan, demokratik, laik ve sosyal bir hukuk devletidir. ” değerin aktarılmaya çalışıldığı düşünülmektedir.

Vatandaş için medeni bilgiler kitapları adalet değeri açısından incelendiğinde; 1 ciltte Demokrasi Prensipinin Bariz Vasıfları başlı̆ğ altında demokrasi özelliğgi üzerinden, Hak İle Vazifenin Münasebeti (görevlerin ilişkileri) başlı̆g altında devletin belirlediği haklar üzerinden ve Vatandaşa Karşı Devletin Vazifeleri başlığı altında devletin görevleri üzerinden değerin aktarılmaya çalışıldığ düşünülmektedir. Kadınların İntihap Selahiyetleri (Seçme Hakları) anlatılırken İş Bölümü Fikri başlığı altında kadın adaleti üzerinden ve İlk Hak, İlk Vazife (görev) bölümünde ve Vergi bölümü anlatılırken Vergi Kaideleri (kuralları) başlı̆ğ altında Adalet konusu üzerinde özellikle durulmuş eşit vergi ödemeleri konusuyla değerin aktarılmaya çalışıldığı düşünülmektedir. Tek Vergi ve Çok Vergiler başlığı altında da vergilerde adalet üzerinden değerin aktarılmaya çalışıldığ düşünülmektedir. Kitabın 2.cildinde ise Adliye bölümünde Vazife başlığı altında adalet kurumunun vazifesi üzerinden adalet değerinin aktarılmaya çalışıldığı düşünülmektedir. Yine aynı ciltte Mahkemeler bölümü anlatılırken Hâkim konu başlığı altında hâkimin görevleri üzerinden adalet değerinin aktarılmaya çalışıldığı düşünülmektedir. 


\section{Aile Birliğine Önem Verme Değeri:}

Tablo 3: 2018 Sosyal Bilgiler Öğretim Programı ile Vatandaş İçin Medeni Bilgiler Kitabının 1. ve

2. Cildinde Aile Birliğine Önem Verme Değerinin Kazandırıldığı Konuların Dağılımları

\begin{tabular}{|c|c|c|c|c|}
\hline $\begin{array}{l}\text { ÖĞRENME } \\
\text { ALANLARI }\end{array}$ & SINIFLAR & $\begin{array}{lcr}\text { AILE BİRLIĞİNE } & \text { ÖNEM VERME } \\
\text { DEĞERININ } & \text { KAZANDIRILDIĞI } \\
\text { KONULAR } & \end{array}$ & $\begin{array}{l}\text { CíLT } \quad 1 \\
\text { KONU } \\
\text { BAȘLIKLARI }\end{array}$ & $\begin{array}{l}\text { CíLT } \quad 2 \\
\text { KONU } \\
\text { BAŞLIKLARI }\end{array}$ \\
\hline Birey ve Toplum & 5. Sinif & Hak ve Sorumluluklarımız & & \multirow{5}{*}{$\begin{array}{l}\text { Aile - Ailede } \\
\text { Vazife }\end{array}$} \\
\hline \multirow{4}{*}{ Kültür ve Miras } & 4. Sinif & Ailemin Tarihi & & \\
\hline & 4. Sinif & Millî Kültür Ögelerimiz & & \\
\hline & 5. Sinif & Kültürümüzü Tanıyalım & & \\
\hline & 6. Sinif & Destan Ve Yazıtlarda Türkler & & \\
\hline
\end{tabular}

Tablo 3 incelendiğinde Aile Birliğine Önem Verme değerinin; Birey ve Toplum öğrenme alanı ile Kültür ve Miras öğrenme alanında aktarılmaya çalışıldığı düşünülmektedir.

Birey ve Toplum öğrenme alanında 5.sınıfta Hak ve Sorumluluklarımız başlığı altında "Sahip olduğu haklarının farkında olan bir birey olarak katıldığ gruplarda aldiğı rollerin gerektirdiği görev ve sorumluluklara uygun davranır." kazanımı üzerinden değerin aktarılmaya çalışıldığı düşünülmektedir. Konu anlatım metninde Aile, toplumun en küçük birimi olarak kabul edilmektedir. Temel ihtiyaçlarımızı ailemizin yardımıyla karşılaşırız cümleleriyle değerin aktarılmaya çalışıldığı düşünülmektedir.

Kültür ve Miras öğrenme alanı içerisinde 4.sınıfta Ailemin Tarihi ve Millî Kültür Öğelerimiz konu başlığı altında "Ailesi ve çevresindeki millî kültürü yansıtan ögeleri araştırarak örnekler verir.” kazanımıyla değerin aktarılmaya çalışıldığ 1 düşünülmektedir. Ailemin Tarihi konu başlığ altında aile bireylerinin birbirlerine güçlü akrabalık bağlarıyla bağlı olduğu ve aile birliğini ve akrabalık bağlarını devam ettirebilmek için ailemizin geçmişini bilmemiz gerektiği vurgulanarak değerin aktarılmaya çalışıldığı düşünülmektedir. Millı̂ Kültür Öğelerimiz konu başlığı altında ise bayramlarda küçükler büyüklerin ellerinden öperken büyükler de onlara çeşitli hediyeler vermeleri ve bu güzel geleneklerimizin aile bireyleri arasındaki saygıyı, aile birliğini ve akrabalık bağlarını güçlendirdiği vurgusu yapılarak değerin doğrudan aktarılmaya çalışıldığ 1 düşünülmektedir. 5.sınıfta Kültürümüzü Tanıyalım konu başlı̆̆ 1 altında "Kültürel ögelerin, insanların bir arada yaşamasındaki rolünü analiz eder." kazanımı üzerinden değerin aktarılmaya çalışıldığı düşünülmektedir. Konu anlatım metnin de dinî, millî veya mevsimlik bayramlarımız bir arada yaşamamıza katkı sağlayan kültürel öğelere örnektir. Ramazan ve Kurban Bayramı dinî bayramlarımızdır. Dinî bayramlarda aile bireyleri bayramlaşır; akrabalar, komşular, arkadaşlar ziyaret edilir cümleleriyle değerin dolaylı olarak aktarılmaya çalışıldığı düşünülmektedir. 6.sınıfta Destan ve Yazıtlarda Türkler konu başlığ altında "Orta Asya'da kurulan ilk Türk devletlerinin coğrafi, siyasal, ekonomik ve kültürel özelliklerine ilişkin çıkarımlarda bulunur." kazanımıyla değerin aktarılmaya çalışıldığı düşünülmektedir. Konu anlatım metini içerisinde sürekli hareket hâlinde bulunan Türk toplumunda aile ve soy birliğinin ön planda olduğu vurgulanarak değerin doğrudan aktarılmaya çalışıldığı düşünülmektedir.

Vatandaş İçin Medeni Bilgiler kitapları aile birliğine önem verme değeri açısından incelendiğinde; kitabın 1.cildinde Aile Birliğine Önem Verme değerinin aktarıldı̆̆ düşünülmemektedir. Kitabın 2.cildinde ise Aile başlığı altında bir bölüm bulunmaktadır. Aile bölümünde Baba, Ana ve Çocuklar konu başlığı altında aileyi oluşturan bireyler üzerinden ve Ailede Vazife konu başlığı altında aile içerisindeki görevler üzerinden aile birliğine önem verme değerinin aktarılmaya çalışıldığı düşünülmektedir. 


\section{Bağımsızlık Değeri:}

Tablo 4: 2018 Sosyal Bilgiler Öğretim Programı ile Vatandaş İçin Medeni Bilgiler Kitabının 1. ve 2. Cildinde Bağımsızlık Değerinin Kazandırıldığı Konuların Dağılımları

\begin{tabular}{|c|c|c|c|c|}
\hline $\begin{array}{l}\text { ÖĞRENME } \\
\text { ALANLARI }\end{array}$ & SINIFLAR & $\begin{array}{l}\text { BAĞIMSIZLIK DEĞERINIIN } \\
\text { KAZANDIRILDIĞI } \\
\text { KONULAR }\end{array}$ & $\begin{array}{l}\text { CİLT } 1 \text { KONU } \\
\text { BAŞLIKLARI }\end{array}$ & $\begin{array}{l}\text { CILT } 2 \text { KONU } \\
\text { BAŞLIKLARI }\end{array}$ \\
\hline \multirow{5}{*}{$\begin{array}{l}\text { Etkin } \\
\text { Vatandaşlık }\end{array}$} & \multirow[t]{2}{*}{ 4. Sinif } & \multirow[t]{2}{*}{ Özgürlük ve Bağımsızlık } & $\begin{array}{l}\text { Diğer Milletlerin Teşekkül } \\
\text { Tarzları }\end{array}$ & \multirow{2}{*}{$\begin{array}{l}\text { Adliye } \\
\text { Hükümlerin } \\
\text { Katiliği } \\
\end{array}$} \\
\hline & & & Devlet & \\
\hline & \multirow{3}{*}{ 5. Sinif } & \multirow{3}{*}{ Bayrağımız ve İstiklâl Marşı } & $\begin{array}{l}\text { Cumhuriyet } \\
\text { Türk Devletinin Esas } \\
\text { Teşkilatı }\end{array}$ & \multirow{3}{*}{ Milli Müdafaa } \\
\hline & & & $\begin{array}{l}\text { Türkiye Cumhuriyeti Nasıl } \\
\text { Oldu }\end{array}$ & \\
\hline & & & Ordu Mekteptir & \\
\hline
\end{tabular}

Tablo 4 incelendiğinde Bağımsızlık değerinin; Etkin Vatandaşlık öğrenme alanında değerin aktarılmaya çalışıldığı düşünülmektedir.

4.sınıfta Özgürlük ve Bağımsızlık başlığı altında "Ülkesinin bağımsızlı̆̆ ile bireysel özgürlüğ̈̈ arasındaki ilişkiyi açıklar. ” kazanımıyla değerin aktarılmaya çalışıldığı düşünülmektedir. Nutuktan alınan konu metninde, "Ne kadar zengin ve refah içinde yaşarsa yaşasın, bağımsızlıktan yoksun bir ulus uygar insanlık karşısında uşak olmaktan öteye gidemez. O hâlde ya bağımsızlık ya ölüm!” cümleleriyle değerin aktarılmaya çalışıldığı düşünülmektedir. 5.sınıfta da Bayrağımız ve İstiklâl Marşı başlığı altında "Millı̂ egemenlik ve bağımsızlık sembollerimizden Bayrağımıza ve Istiklâl Marşına değer verir.” kazanımıyla değerin aktarılmaya çalışıldığı düşünülmektedir. Konu anlatım metninde "Bir milletin bağımsız ve hür bir şekilde yaşamasına, başka bir devlete bağımlı olmadan özgürce karar verebilmesine millî bağımsızlık denir.” milli bağımsızlığın tanımı yapılarak değerin aktarılmaya çalışıldığ 1 düşünülmektedir.

Vatandaş İçin Medeni Bilgiler kitapları bağımsızlık değeri açısından incelendiğinde; değerin doğrudan aktarılmaya çalışıldığı düşünülmektedir. Kitabın 1.cildinde Millet bölümünde Diğer Milletlerin Teşekkül (kurulma) Tarzları konu başlı̆̆ altında da dolaylı olarak bağımsızlık değerininaktarılmaya çalışıldığ 1 düşünülmektedir. Cumhuriyet bölümünde Türk Devletinin Esas Teşkilatı konu başlığı altında da millet hakimiyeti üzerinden, Türkiye Cumhuriyeti Nasıl Oldu ve Ordu Mekteptir başlığı altında Türk istiklali ve Gençliğe Hitabe üzerinden bağımsızlık değerinin doğrudan aktarılmaya çalışıldığı düşünülmektedir. Kitabın 2. cildinde ise bağımsızlık değeri Adliye bölümü altındaki Hükümlerin Katiliği (Kesinliği) başlığı altında mahkemelerin bağımsızlığı üzerinden ve Milli Müdafaa başlığı altında milli müdafaanın önemi üzerinden doğrudan aktarılmaya çalışıldığı düşünülmektedir. 


\section{Barış Değeri}

Tablo 5: 2018 Sosyal Bilgiler Öğretim Programı ile Vatandaş İçin Medeni Bilgiler Kitabının 1. ve 2. Cildinde Barış Değerinin Kazandırıldığı Konuların Dağılımları

\begin{tabular}{|c|c|c|c|c|}
\hline $\begin{array}{l}\text { ÖĞRENME } \\
\text { ALANLARI }\end{array}$ & SINIFLAR & $\begin{array}{l}\text { BARIŞ DEĞERINININ } \\
\text { KAZANDIRILDIĞI } \\
\text { KONULAR }\end{array}$ & $\begin{array}{l}\text { CİLT } 1 \text { KONU } \\
\text { BAŞLIKLARI }\end{array}$ & $\begin{array}{l}\text { CİLT } 2 \text { KONU } \\
\text { BAŞLIKLARI }\end{array}$ \\
\hline \multirow{2}{*}{ Kültür ve Miras } & 6. Sinif & Yeni Yurt Anadolu & \multirow{5}{*}{$\begin{array}{l}\text { Kadınların intihap } \\
\text { Selahiyetleri }\end{array}$} & \multirow{2}{*}{ Hariciye } \\
\hline & 6. Sinif & Medeniyete Yön Veren Yollar & & \\
\hline \multirow{2}{*}{ Etkin Vatandaşlık } & 6. Sinif & Kadın ve Toplum & & \multirow{2}{*}{ Hariciye Vekaleti } \\
\hline & 7. Sinif & Demokrasi Serüveni & & \\
\hline \multirow{6}{*}{$\begin{array}{l}\text { Küresel } \\
\text { Bağlantılar }\end{array}$} & 4. Sinif & Komşularımız & & \multirow{2}{*}{ Hükümet Teşkilatı } \\
\hline & 4. Sinif & Dünya Farklılıklarla Güzel & \multirow{5}{*}{ İş Bölümü Fikri } & \\
\hline & 6. Sinif & Komşularımız ve Kardeşlerimiz & & \multirow{4}{*}{$\begin{array}{l}\text { Devlet } \\
\text { Arasinda } \\
\text { Mesai }\end{array}$} \\
\hline & 6. Sinif & Ticari İlişkilerimiz & & \\
\hline & 6. Sinif & Lider Türkiye & & \\
\hline & 7. Sinif & Türkiye'de ve Dünyada Barış & & \\
\hline
\end{tabular}

Tablo 5 incelendiğinde Barış değerinin; Kültür ve Miras, Etkin Vatandaşlık ve Küresel Bağlantılar öğrenme alanlarında aktarılmaya çalışıldığı düşünülmektedir.

Kültür ve miras öğrenme alanında 6.sınıfta Yeni Yurt Anadolu başlı̆̆1 altında "Türklerin Anadolu'yu yurt edinme sürecini XI ve XIII. yüzylllar kapsamında analiz eder. " kazanımı ile değerin aktarılmaya çalışıldığı düşünülmektedir. Konu anlatım metninde Malazgirt savaşından önce barış teklifinde bulunmak için imparatora elçiler gönderildiği ve Alparslan'ın iki devlet arasında sağlam bir dostluk ve daimî bir barış kurulmasını teklif etiği aktarılarak değerin doğrudan aktarılmaya çalışıldığ1 düşünülmektedir. Medeniyete Yön Veren Yollar başlığı altında da "Tarihî ticaret yollarının toplumlar arası siyasi, kültürel ve ekonomik ilişkilerdeki rolünü açıklar." kazanımıyla değerin aktarılmaya çalışıldığı düşünülmektedir. Bu konu içerisinde de ticaret yolları üzerinde durulurken İpek Yolu'na hâkim devletlerin yol üzerinde barış1 korumaya da özen gösterdikleri vurgulanarak değerin doğrudan aktarılmaya çalışıldığı düşünülmektedir.

Etkin Vatandaşlık öğrenme alanında 6.sınıfta Kadın ve Toplum konu başlığı altında "Türk tarihinden ve güncel örneklerden yola çıkarak toplumsal hayatta kadına verilen değeri fark eder." kazanımı doğrultusunda değerin aktarılmaya çalışıldığı düşünülmektedir. Konu aktarılırken pozitif ayrımcılık üzerinden çocukları, kadınları ve yaşlıları koruyucu özel yasalar çıkarılması adalet duygusunu tatmin ettiği için toplumsal barışa daha fazla katkı sağlayacağı yönündeki cümlelerle değerin doğrudan aktarılmaya çalışıldığı düşünülmektedir. 7.sınıfta da Demokrasi Serüveni başlığı altında "Demokrasinin ortaya çıkışını, gelişsim evrelerini ve günümüzde ifade ettiği anlamları açıklar." kazanımı yoluyla değerin aktarılmaya çalışıldığı düşünülmektedir. Konu metninde "Site" adı verilen eski Yunan kent devletleri üzerinden sitelerde halk agora adı verilen meydanda toplanıp bir meclis oluşturduğu ve yasaları kabul eden, savaşa, barışa ve vergi toplanmasına karar veren organın bu meclis olduğu belirtilerek değerin aktarılmaya çalışıldığı düşünülmektedir.

Küresel Bağlantılar öğrenme alanında 4.sınıfta Komşularımız konu başlığı altında “Türkiye'nin komşulart ve diğer Türk Cumhuriyetleri ile olan ilişkilerini kavrar." kazanımı yoluyla değerin aktarılmaya çalışıldığı düşünülmektedir. Konu metninde Türkiye'nin, komşusu olan Irak’ta güvenliğin ve iç barışın sağlanması ve ülkenin toprak bütünlügünün korunmasına yönelik bir dış politika izlediği belirtilerek değerin aktarılmaya çalışıldığı düşünülmektedir. 4.sınıfın diğer bir konusu olan Dünya Farklı1ıklarla Güzel konu başlığında "Farklı kültürlere saygı gösterir. " kazanımı yoluyla değerin aktarılmaya çalışıldığı düşünülmektedir. Konu anlatım metnin de farklılıklara saygı gösterildiği ölçüde insanlar arasındaki düşmanlık duyguları ve ön yargıların ortadan kalktığı ve böylece barışın ve sevginin hâkim olduğu, insan onurunu yücelten bir dünya kurulabileceğini belirten cümleler doğrultusunda değerin aktarılmaya çalışıldığı düşünülmektedir. 6.sınıfta Komşularımız ve Kardeşlerimiz başlığı altında "Ülkemizin Türk Cumhuriyetleri ve komşu devletlerle olan kültürel, 
sosyal, siyasi ve ekonomik ilişkilerini analiz eder." kazanımı yoluyla değerin aktarılmaya çalışıldığ1 düşünülmektedir. Konu anlatım metninde Türkiye'nin Yurtta barış dünyada barış ilkesi ile bir taraftan yurt içinde huzuru sağlayarak güven içinde yaşamayı amaçlarken diğer taraftan da uluslararası barış ve güvenliği savunduğu belirtilerek değerin aktarılmaya çalışıldığ1 düşünülmektedir. Ayrıca Ticari İlişkilerimiz konu başlığı altında "Ülkemizin diğer ülkelerle olan ekonomik iliş̧kilerini analiz eder." kazanımı yoluyla Türkiye'nin birçok ülkeyle barış ve dostluk temeline dayanan ekonomik, kültürel, siyasi ve sosyal ilişkileri olduğu belirtilerek ve Lider Türkiye konu başlığı altında "Ülkemizin sahip olduğu siyasi, askerî, ekonomik ve kültürel özelliklere bağlı olarak uluslararası alanda üstlendiği rolleri analiz eder. " kazanımı yoluyla Türkiye'nin barışa katkı sağlamak için binlerce askeriyle dünyanın dört bir yanında görev yaptığı aktarılarak değerin aktarılmaya çalışıldığ 1 düşünülmektedir. 7.sınıfta ise Türkiye'de ve Dünyada Barış başlığ 1 altında "Türkiye’nin üyesi olduğu uluslararası kuruluşlara örnekler verir." kazanımı yoluyla birçok uluslararası kuruluşa üye olan ülkemiz bölgesinin ve dünyanın barış ve huzuruna hizmet ettiği belirtilerek değer hem ünite hem de içerik üzerinden doğrudan aktarılmaya çalışıldığ düşünülmektedir.

Vatandaş İçin Medeni Bilgiler kitapları barış değeri açısından incelendiğinde; kitabın 1.cildinde Kadınların İntihap Selahiyetleri (Seçme Hakları) anlatılırken İş Bölümü Fikri başlı̆̆ altında kadınların barışsever olduğu düşüncesi üzerinden değerin doğrudan aktarılmaya çalışıldığı düşünülmektedir. Kitabın 2.cildinde ise Hariciye (Dışişleri) bölümünde Hariciye Vekaleti (Dışişleri Bakanlığı) konu başlığı altında vekaletin görevleri üzerinden ve Hükümet Teşkilatı bölümünde Devlet Teşkilatı Arasında teşriki Mesai (İş birliği) başlığı altında hükümet işleri üzerinden barış değerinin aktarılmaya çalışıldığı düşünülmektedir.

\section{Bilimsellik Değeri:}

Tablo 6: 2018 Sosyal Bilgiler Öğretim Programı ile Vatandaş İçin Medeni Bilgiler Kitabının 1. ve 2. Cildinde Bilimsellik Değerinin Kazandırıldığı Konuların Dağılımları

\begin{tabular}{|c|c|c|c|c|}
\hline $\begin{array}{l}\text { ÖĞRENME } \\
\text { ALANLARI } \\
\end{array}$ & SINIFLAR & $\begin{array}{lc}\text { BİLİMSELLIK } & \text { DEĞERİNIN } \\
\text { KAZANDIRILDIĞI KONULAR }\end{array}$ & $\begin{array}{l}\text { CILLT } 1 \text { KONU } \\
\text { BAŞLIKLARI }\end{array}$ & $\begin{array}{l}\text { CİLT } 2 \text { KONU } \\
\text { BAŞLIKLARI }\end{array}$ \\
\hline Birey ve Toplum & 5. Sinif & Hak ve Sorumluluklarımız & \multirow{4}{*}{ Hürriyet } & \multirow{4}{*}{$\begin{array}{l}\text { Hükümet } \\
\text { Teşkilatı }\end{array}$} \\
\hline Kültür Ve Miras & 7. Sinif & Avrupa'da Uyanış & & \\
\hline \multirow{9}{*}{$\begin{array}{l}\text { Bilim. Teknol } \\
\text { Toplum }\end{array}$} & 4. Sinif & Geçmişten Bugüne Teknoloji & & \\
\hline & 4. Sinif & Zaman İçinde Teknoloji & & \\
\hline & 5. Sinif & Bilim İnsanlarının Ortak Özellikleri & \multirow{3}{*}{$\begin{array}{l}\text { Hürriyetin } \\
\text { Muhtelif } \\
\text { Şekilleri }\end{array}$} & \multirow{3}{*}{$\begin{array}{l}\text { Devlet Teşkilatı } \\
\text { Arasında Teşriki } \\
\text { Mesai }\end{array}$} \\
\hline & 5. Sinif & Bilimsel Etik & & \\
\hline & 6. Sinif & Sosyal Bilimler ve Toplum & & \\
\hline & 6. Sinif & Hayalimdeki Gelecek & \multirow{4}{*}{ Gazeteler } & \\
\hline & 7. Sinif & Bilimin Öncüleri & & \\
\hline & 7. Sinif & Her Yenilik Geleceğimize Bir Katkıdır & & \\
\hline & 7. Sinif & Özgür Düşüncenin Bilime Katkısı & & \\
\hline
\end{tabular}

Tablo 6 incelendiğinde Bilimsellik değerinin; Birey ve Toplum, Kültür ve Miras öğrenme alanları ile Bilim, Teknoloji ve Toplum öğrenme alanında aktarılmaya çalışıldığı düşünülmektedir.

Birey ve Toplum öğrenme alanında 5.sınıfta Hak ve Sorumluluklarımız konu başlığında

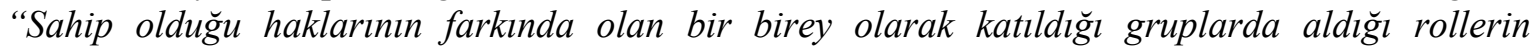
gerektirdiği görev ve sorumluluklara uygun davranır." kazanımı yoluyla değerin aktarılmaya çalışıldığ araçlarının bireyin planlı hareket edebilmesinin önündeki önemli bir engel olduğu aktarılarak değerin dolaylı yolla aktarılmaya çalışıldığı düşünülmektedir.

Kültür ve Miras öğrenme alanında 7.sınıfta Avrupa'da Uyanış başlığı altında “Avrupa'daki gelişmelerle bağlantılı olarak Osmanlı Devleti'ni değişime zorlayan süreçleri kavrar.” kazanımı yoluyla değerin aktarılmaya çalışıldığı düşünülmektedir. Aydınlanma çağı hakkında kitap metninde 
Aydınlanma Çağı'nda her konuda aklın üstünlüğüne, bilimsel araştırmalarda doğayı incelemeye, deney ve gözlem yapmaya önem verildiği, Coğrafi Keşifler aktarılırken de Coğrafi keşiflerden elde edilen zenginliğin, bilimsel buluş ve icatlarla birleşerek üretime dönüş̧ürülmesiyle sanayi devriminin gerçekleştiği belirtilerek değerin aktarılmaya çalışıldığı düşünülmektedir.

Bilim, Teknoloji ve Toplum öğrenme alanında 4.sınıfta Geçmişten Bugüne Teknoloji başlığı altında "Teknolojik ürünlerin geçmişteki ve bugünkü kullanımlarını karşılaştırır. " kazanımı yoluyla değerin aktarılmaya çalışıldığ 1 düşünülmektedir. Konu anlatım metninde bilimdeki gelişmeler ve değişen ihtiyaçlara bağlı olarak zaman içinde iyileştirilerek daha kullanışlı hâle getirildiği aktarılarak değerin aktarılmaya çalışıldığı düşünülmektedir. 4.sınıfın diğer bir konusu olan Zaman İçinde Teknoloji başlığı altında da "Kullandığı teknolojik ürünlerin mucitlerini ve bu ürünlerin zaman içerisindeki gelişimini araştırır." kazanımı doğrultusunda değerin aktarılmaya çalışıldı̆̆ düşünülmektedir. Konu anlatım metni içerisinde Graham Bell'in icat ettiği sabit telefonla haberleşmek için dünyanın her yerine kablo döşenmesi gerektiği, ancak bunun çok zor ve masraflı bir iş olduğu bunun üzerine bilim insanlarının çalışmalarını telsiz haberleşme üzerinde yoğunlaştırdığını belirterek değerin dolaylı olarak aktarılmaya çalışıldığı düşünülmektedir. 5.sınıfta Bilim İnsanlarının Ortak Özellikleri konu başlı̆̆ altında "Buluş yapanların ve bilim insanlarının ortak özelliklerini belirler." kazanımı yoluyla değerin aktarılmaya çalışıldığı düşünülmektedir. Konunun aktarıldığı metinde ise; mevcut bilgileri kullanarak yeni bilgiler ortaya çıkarma çabasına bilimsel düşünme dendiği, bilim insanları yaptıkları çalışmaları bilimsel düşünme sayesinde ortaya koydukları belirtilerek değerin aktarılmaya çalışıldığı düşünülmektedir. 7.sınıfın diğer bir konusu olan Bilimsel Etik konu başlığında "Yaptığı çalışmalarda bilimsel etiğe uygun davranır." kazanımı yoluyla değerin aktarılmaya çalışıldığ 1 düşünülmektedir. Ders kitabında yer alan metinde bilimsel çalışma yaparken farklı kaynaklardan bilgi edindiğimiz ve Bilimsel kitapların, süreli yayınların, ansiklopedilerin ve Genel Ağ'ın temel bilgi kaynakları oldukları belirtilerek değerin aktarılmaya çalış1ldığ1 düşünülmektedir. 6.sınıfta Sosyal Bilimler ve Toplum başlı̆̆ 1 altında "Sosyal bilimlerdeki çalışma ve bulgulardan hareketle sosyal bilimlerin toplum hayatına etkisine örnekler verir." kazanımı üzerinden değerin aktarılmaya çalışıldığı düşünülmektedir. Konu anlatım metni içerisinde bilimsel düşünme becerisinin halk içinde yayılması için çaba harcandığ 1 aktarılarak değerin aktarılmaya çalışıldığı düşünülmektedir. 6.sınıfın konusu olan Hayalimdeki Gelecek konu başlığ1 altında da "Bilimsel ve teknolojik gelişmelerin gelecekteki yaşam üzerine etkilerine ilişkin fikirler ileri sürer." kazanımı yoluyla değerin aktarılmaya çalışıldığı düşünülmektedir. Konu anlatım metninde Jules Verne'nin (Jul Vern), 1865 yılında "Ay’a Seyahat" romanını yazdığında, “Ay'da yaşam var mıdır?" sorusu bilimsel olarak ele alınamaz bir soru olduğu belirtilerek değerin aktarılmaya çalışıldığı düşünülmektedir. 7.sınıfta da Bilimin Öncüleri konu başlığı altında "Türkİslam medeniyetinde yetişen bilginlerin bilimsel gelişme sürecine katkılarını tartışır." kazanımı üzerinden aktarıldığı düşünülen değer anlatım metninde yer alan Orta Çağ Avrupası'nda skolastik düşüncenin etkisiyle bilimsel ilerleme yavaşlamıştır cümlesiyle, Her Yenilik Geleceğimize Bir Katkıdır konu başlığı altında “ $X V$-XX. yüzyıllar arasında Avrupa'da yaşanan gelişmelerin günümüz bilimsel birikiminin oluşmasına etkisini analiz eder." kazanımı üzerinden anlatım metninde yer alan XV-XX. yüzyıllar arasında Avrupa'da yaşanan gelişmelerin günümüzdeki bilimsel birikiminin oluşmasına büyük katkısı olmuştur cümlesiyle ve Özgür Düşüncenin Bilime Katkısı konu başlığı altında "Özgür düşüncenin bilimsel gelişmelere katkısını değerlendirir. " kazanımı üzerinden anlatım metnindeki Avrupa'da özgür düşüncenin yasaklandığ 1 Orta Çağ'da İslam coğrafyasında bilimsel gelişmeler altın çağını yaşıyordu cümlesiyle bilimsellik değerinin aktarılmaya çalışıldığı düşünülmektedir.

Vatandaş İçin Medeni Bilgiler kitapları Bilimsellik değeri açısından incelendiğinde; kitabın 1.cildinde Hürriyet bölümünde Hürriyetin Muhtelif (Çeşitli) Şekilleri başlığı altında mesleklerde bilimsel yetkinliğe sahip olmanın gerekliliği ve aynı bölümün Tedris (Öğrenim Hürriyeti) başlığ1 altında da öğretimin önemi üzerinden değerin aktarılmaya çalışıldığı düşünülmektedir. Kitabın 
2.cildinde ise; Hükümet Teşkilatı bölümünde Devlet Teşkilatı Arasında teşriki Mesai başlığı altında hükümet işleri ele alınırken ve Maarif (Eğitim) bölümünde Bilgi bütün hayatın ruhudur sözüyle bilimsellik değerinin aktarılmaya çalışıldığ 1 düşünülmektedir.

\section{6. Çalışkanlık Değeri}

Tablo 7: 2018 Sosyal Bilgiler Öğretim Programı ile Vatandaş İçin Medeni Bilgiler Kitabının 1. ve 2. Cildinde Çalışkanlık Değerinin Kazandırıldığg Konuların Dăğıımları

\begin{tabular}{|c|c|c|c|c|}
\hline $\begin{array}{l}\text { ÖĞRENME } \\
\text { ALANLARI }\end{array}$ & SINIFLAR & $\begin{array}{l}\text { ÇALIŞKANLIK DEĞERİNİN } \\
\text { KAZANDIRILDIĞI } \\
\text { KONULAR }\end{array}$ & $\begin{array}{l}\text { CÍLT } 1 \text { KONU } \\
\text { BAŞLIKLARI }\end{array}$ & $\begin{array}{l}\text { CILT } \quad 2 \\
\text { KONU } \\
\text { BAŞLIKLARI }\end{array}$ \\
\hline Birey ve Toplum & 6. Sinif & Ön Yargıları Kırıyorum & Çalışma, Meslek & \multirow[b]{2}{*}{ Siyasi F1kralar } \\
\hline $\begin{array}{l}\text { Bilim, Teknoloji ve } \\
\text { Toplum }\end{array}$ & 5. Sinif & $\begin{array}{l}\text { Bilim İnsanlarının Ortak } \\
\text { Özellikleri }\end{array}$ & $\begin{array}{l}\text { Meslek Nasil İntihap } \\
\text { Olunur ve Yapılır }\end{array}$ & \\
\hline $\begin{array}{l}\text { Üretim, Dağıtım ve } \\
\text { Tüketim }\end{array}$ & 5. Sinif & Yeni Fikirler Geliştirelim & $\begin{array}{lr}\text { Vatandaşın } & \text { Devlete } \\
\text { Karşı Başlıca Vazifeleri }\end{array}$ & \multirow[t]{2}{*}{ Memurlar } \\
\hline Küresel Bağlantılar & 7. Sinif & İnsanları Nasıl Tanıyoruz & Ordu Mekteptir & \\
\hline
\end{tabular}

Tablo 7 incelendiğinde Çalışkanlık değerinin; Birey ve Toplum, Bilim, Teknoloji ve Toplum, Üretim, Dağıtım ve Tüketim ile Küresel Bağlantılar öğrenme alanlarında aktarılmaya çalış1ldığ1 düşünülmektedir.

Birey ve Toplum öğrenme alanında 6.sınıfta Ön Yargıları Kırıyorum başlığı altında “Toplumda uyum içerisinde yaşayabilmek için farklılıklara yönelik ön yargıları sorgular." kazanımı üzerinden değerin aktarılmaya çalışıldığı düşünülmektedir. Konu anlatımı yapılan haber metninde, "Onu tanıdıkça daha da pişman oldum. Çok tertipli, azimli ve çalışkandl." ve "Büyük şirketlerde üst düzey yönetici olmayı hedeflediğini belirten Akkaya azmi ve çalışkanlığlyla çevresindekilerin ve tüm Türkiye'nin takdirini topladı. " cümleleriyle değerin aktarılmaya çalış1ldığı düşünülmektedir.

Bilim, Teknoloji ve Toplum öğrenme alanında 5.sınıfta Bilim İnsanlarının Ortak Özellikleri başlığı altında "Buluş yapanların ve bilim insanlarının ortak özelliklerini belirler." kazanımı üzerinden değerin dolaylı olarak aktarılmaya çalışıldığı düşünülmektedir.

Üretim, Dağıtım ve Tüketim öğrenme alanında 5.sınıfta Yeni Fikirler Geliştirelim başlığı altında "IŞ̧ birliği yaparak üretim, dağıtım ve tüketime dayalı yeni fikirler geliştirir." kazanımı üzerinden girişimcilerin özellikleri sayılmaktadır. Bu özellikler arasında çalışkanlık değerinin aktarılmaya çalışıldığı düşünülmektedir.

Küresel Bağlantılar öğrenme alanında da 7.sınıfta İnsanları Nasıl Tanıyoruz başlığı altında “Çeşitli kültürlere yönelik kalıp yargıları sorgular.” kazanımı üzerinden çeşitli kültürlere yönelik kalıp yargılar işlenmekte ve bu yol üzerinden değerin aktarılmaya çalışıldığı düşünülmektedir.

Vatandaş İçin Medeni Bilgiler kitapları Çalışkanlık değeri açısından incelendiğinde; kitabın 1.cildinde Çalışma, Meslek başlığı altında Atatürk'ün sözleri üzerinden, Meslek Nasıl İntihap Olunur ve Yapılır (Seçilir ve Yapılır) başlı̆̆ 1 altında servet kazanma üzerinden değerin aktarılmaya çalışıldığı düşünülmektedir. Vatandaşın Devlete Karşı Başlıca Vazifeleri bölümünde Ordu Mekteptir (Okul) başlığı altında da çalışkanlık değerinin aktarılmaya çalışıldığı düşünülmektedir. Kitabın 2.cildinde ise; Siyasi Fıkralar (Partiler) başlığı altında siyasi partiye giriş üzerinden, Memurlar bölümünde Sicil, Mahrem (Gizli) Dosya, Hüviyet Kâğıdı (Nüfus Cüzdanı) başlığı altında sicil üzerinden çalışkanlık değerinin aktarılmaya çalışıldığı düşünülmektedir. 


\section{Dayanışma Değeri:}

Tablo 8: 2018 Sosyal Bilgiler Öğretim Programı ile Vatandaş İçin Medeni Bilgiler Kitabının 1. ve 2. Cildinde Dayanışma Değerinin Kazandırıldığı Konuların Dağılımları

\begin{tabular}{|c|c|c|c|c|}
\hline $\begin{array}{l}\text { ÖĞRENME } \\
\text { ALANLARI }\end{array}$ & SINIFLAR & $\begin{array}{l}\text { DAYANIŞMA } \quad \text { DEĞERINIIN } \\
\text { KAZANDIRILDIĞI KONULAR }\end{array}$ & $\begin{array}{l}\text { CİLT } 1 \text { KONU } \\
\text { BAŞLIKLARI }\end{array}$ & $\begin{array}{l}\text { CILT } \\
\text { KONU } \\
\text { BAŞLIKLARI }\end{array}$ \\
\hline \multirow{3}{*}{ Birey ve Toplum } & 6. Sinif & Değişen Rollerim & \multirow{4}{*}{$\begin{array}{l}\text { Millet } \\
\text { Türk Yurdu }\end{array}$} & \multirow{11}{*}{$\begin{array}{l}\text { Devlet } \\
\text { Teşkilatı } \\
\text { Arasında } \\
\text { teşriki Mesai }\end{array}$} \\
\hline & 6. Sinif & Kültürümüzle Yaşıyor ve Gelişiyoruz & & \\
\hline & 6. Sinif & Birlikte Daha Güçlüyüz & & \\
\hline Kültür ve Miras & 5. Sinif & Kültürümüzü Tanıyalım & & \\
\hline $\begin{array}{lll}\text { İnsanlar, } & \text { Yerler } & \text { ve } \\
\text { Çevreler } & & \end{array}$ & 5. Sinif & Doğal Afetlerin Yaşamımıza Etkisi & \multirow{2}{*}{$\begin{array}{l}\text { Milletin Umumi } \\
\text { Tanımı }\end{array}$} & \\
\hline \multirow{3}{*}{$\begin{array}{l}\text { Üretim, Dağıtım ve } \\
\text { Tüketim }\end{array}$} & 5. Sinif & Ekonomi ve Sosyal Hayat & & \\
\hline & 6. Sinif & Mesleğimi Seçiyorum & \multirow{2}{*}{$\begin{array}{l}\text { Vatandaşa Karş1 } \\
\text { Devletin } \\
\text { Vazifeleri }\end{array}$} & \\
\hline & 7. Sinif & Vakıf Demek, Medeniyet Demek & & \\
\hline \multirow{3}{*}{ Etkin Vatandaşlık } & 4. Sinif & $\begin{array}{lll}\text { Eğitsel ve } & \text { Sosyal } & \text { Etkinliklere } \\
\text { Katıllyorum } & & \\
\end{array}$ & \multirow{3}{*}{ Bağlılık } & \\
\hline & 5. Sinif & Halka Hizmet Veren Kurumlar & & \\
\hline & 7. Sinif & Cumhuriyetimi Seviyorum & & \\
\hline
\end{tabular}

Tablo 8 incelendiğinde Dayanışma değerinin; Birey ve Toplum, Kültür ve Miras, İnsanlar, Yerler ve Çevreler, Üretim, Dağıtım ve Tüketim ile Etkin Vatandaşlık öğrenme alanlarında aktarılmaya çalışıldığı düşünülmektedir.

Birey ve Toplum öğrenme alanında 6.sınıfta Değiş̧en Rollerim başlığı altında "Sosyal rollerin zaman içerisindeki değişimini inceler." kazanımı üzerinden değerin aktarılmaya çalışıldığı düşünülmektedir. Konu anlatım metninde aile içerisindeki roller aktarılırken sevinçlerimizin ve üzüntülerimizin paylaşıldı̆̆ i ilk yer olan ailemiz hayatımız boyunca yer alacağımız gruplar içinde en önemlisi olduğu ve bu yüzden aile içi roller sevgi, saygı, dayanışma ve yardımseverlik duygularıyla yerine getirilmesi gerektiği belirtilerek değerin doğrudan aktarılmaya çalışıldığı düşünülmektedir. 6.sınıfta Kültürümüzle Yaşıyor ve Gelişiyoruz başlığı altında "Sosyal, kültürel ve tarihî bağların toplumsal birlikteliğin oluşmasındaki yerini ve rolünü analiz eder." kazanımı üzerinden değerin aktarılmaya çalışıldığı düşünülmektedir. Konu anlatım içeriğinde toplumsal yaşamın vazgeçilmezi olan değerlerin, örf ve âdetlerin, gelenek ve göreneklerin dil vasıtası ile nesilden nesile aktarıldığ 1 belirtilirken dayanışma değerinin dolaylı olarak aktarılmaya çalışıldığı düşünülmektedir.

6.sınıfın diğer bir konusu olan Birlikte Daha Güçlüyüz başlığı altında da "Toplumsal birlikteliğin oluşmasında sosyal yardımlaşma ve dayanışmayı destekleyici faaliyetlere katılır." kazanımı üzerinden değerin aktarılmaya çalışıldığı düşünülmektedir. Konu anlatım metninde İnsanların beslenme, giyinme, barınma, eğitim, sağlık gibi ihtiyaçlarını karşılamak için kurumsal bir düzene gereksinim duydukları, sosyal yardımlaşma ve dayanışmanın da bu ihtiyaçları karşılamak üzere ortaya çıktığı, toplumun ekonomik yapısını dengede tutan, birlik ve beraberliği artıran değerlerden olduğu belirtilerek değerin doğrudan aktarılmaya çalışıldığı düşünülmektedir.

Kültür ve Miras öğrenme alanında 5.sınıfta Kültürümüzü Tanıyalım başlığı altında "Külttürel ögelerin, insanların bir arada yaşamasındaki rolünü analiz eder." kazanımı üzerinden değerin aktarılmaya çalış1ldı̆̆ düşünülmektedir.

Konu anlatım metninde kültürel unsurların; milletin kaynaşmasını, dayanışmasını, birlik ve beraberlik içinde yaşamasını sağladığı için önemli olduğu belirtilerek değerin doğrudan aktarılmaya çalış1ldığ1 düşünülmektedir.

İnsanlar, Yerler ve Çevreler öğrenme alanında 5.sınıfta Doğal Afetlerin Yaşamımıza Etkisi başlığı altında "Doğal afetlerin toplum hayatı üzerine etkilerini örneklerle açıklar." kazanımı üzerinden değerin dolaylı olarak aktarılmaya çalışıldığı düşünülmektedir. 
Üretim, Dağıtım ve Tüketim öğrenme alanında 5.sınıfta Ekonomi ve Sosyal Hayat başlığ1 altında "Çevresindeki ekonomik faaliyetlerin, insanların sosyal hayatlarına etkisini analiz eder." kazanımı üzerinden değerin aktarılmaya çalışıldığı düşünülmektedir. Konu anlatım metni içerisinde insanların düğ̈̈n, kına gecesi ve sünnet gibi sosyal aktivitelerini evlerinin önünde yaptığı, ailelerinden gördükleri kültürel değerleri korumaya özen gösterdikleri ve insanlar arasında yardımlaşma ve dayanışmanın oldukça güçlü olduğu aktarılarak değerin doğrudan aktarılmaya çalış1ldı̆̆ düşünülmektedir.

6.sınıfta Mesleğimi Seçiyorum başlığı altında mesleğin kişisel özellikleri üzerinden "İlgi duyduğu mesleklerin gerektirdiği kişilik özelliklerini, becerileri ve eğitim sürecini araştırır." kazanımı üzerinden değerin aktarılmaya çalışıldığı düşünülmektedir. Konu içeriğinde insanların ilgi, yetenek ve değerlerinin çok farklı olduğu, aynı zamanda toplumun farklı ihtiyaçlarının bulunduğu ve bunun sonucunda mesleklerin ortaya çıktığı aktarılarak dayanışma gerektiren meslekler üzerinden değerin doğrudan aktarılmaya çalışıldığı düşünülmektedir. 7.sınıfta da Vakıf Demek, Medeniyet Demek başlığı altında "Kurumların ve sivil toplum kuruluşlarının çalışmalarına ve sosyal yaşamdaki rollerine örnekler verir. " kazanımı üzerinden değerin aktarılmaya çalışıldığ düşünülmektedir. Konu içeriğinde geçmişten günümüze toplumların kendi yapıları içinde sosyal yardım, dayanışma ve güvenlik ihtiyaçlarını gidermek amacıyla kurumlar oluşturdukları belirtilerek değerin doğrudan aktarılmaya çalışıldığ 1 düşünülmektedir.

Etkin Vatandaşlık öğrenme alanında 4.sınıfta Eğitsel ve Sosyal Etkinliklere Katılıyorum başlı̆̆ altında "Okul yaşamında gerekli gördüğü eğitsel sosyal etkinlikleri önerir." kazanımı üzerinden değerin aktarılmaya çalışıldığı düşünülmektedir. Konu anlatım içeriğinde etkinlik yoluyla kardeş okula ziyaret yapıldığı ve bu kardeş okuldan dostluk ve dayanışma duygularının daha da güçlendiğini hissederek ayrıldıkları belirtilerek değerin doğrudan aktarılmaya çalışıldığı düşünülmektedir. 5.sınıfta Halka Hizmet Veren Kurumlar başlı̆̆1 altında "Bireysel ve toplumsal ihtiyaçlar ile bu ihtiyaçların karşılanması için hizmet veren kurumları iliş̧ilendirir." kazanımı üzerinden değerin aktarılmaya çalışıldığ düşünülmektedir. Konu içeriğinde sivil toplum kuruluşlarının özellikleri arasında ki çalışanlar arasında yardımlaşma ve dayanışma, birlik ve beraberlik duygusu vardır maddesi vasıtasıyla değerin doğrudan aktarılmaya çalışıldığı düşünülmektedir. 7.sınıfta da Cumhuriyetimi Seviyorum başlığı altında "Türkiye Cumhuriyeti Devleti'nin temel niteliklerini toplumsal hayattaki uygulamalarla ilişkilendirir. " kazanımı üzerinden değerin aktarılmaya çalışıldığı düşünülmektedir. Konu aktarımında devletin temel nitelikleri üzerinde durulurken Türkiye Cumhuriyeti'nin, toplumun huzuru, millî dayanışma ve adalet anlayış1 içinde, insan haklarına saygıll, Atatürk milliyetçiliğine bağlı, başlangıçta belirtilen temel ilkelere dayanan, demokratik, laik ve sosyal bir hukuk devleti olduğu belirtilerek değerin doğrudan aktarılmaya çalışıldığı düşünülmektedir.

Vatandaş İçin Medeni Bilgiler kitapları Dayanışma değeri açısından incelendiğinde; kitabın 1.cildinde Millet bölümünde Türk Yurdu başlı̆̆ altında vatan üzerinden, Milletin Umumi (Genel) Tanımı başlığı altında millet tanımı üzerinden, Vatandaşa Karşı Devletin Vazifeleri başlığı altında üretim artışı üzerinden ve Bağl1lık başlığ 1 altında insanların birbirine bağlılı̆̆g üzerinden değerin aktarılmaya çalışıldığ düşünülmektedir. Kitabın 2. cildinde ise; Devlet Teşkilatı Arasında teşriki Mesai (İş birliği) başlığı altında iş birliği üzerinden dayanışma değerinin aktarılmaya çalışıldığı düşünülmektedir. 


\section{Duyarlılık Değeri:}

Tablo 9: 2018 Sosyal Bilgiler Öğretim Programı ile Vatandaş İçin Medeni Bilgiler Kitabının 1. ve 2. Cildinde Duyarlılık Değerinin Kazandırıldı ğı Konuların Dağılımları

\begin{tabular}{|c|c|c|c|c|}
\hline ÖĞRENME ALANLARI & SINIFLAR & $\begin{array}{l}\text { DUYARLILIK DEĞERININ } \\
\text { KAZANDIRILDIĞI KONULAR } \\
\end{array}$ & $\begin{array}{l}\text { CİLT } 1 \text { KONU } \\
\text { BASSLIKLARI } \\
\end{array}$ & \begin{tabular}{|l|} 
CILLT 2 KONU \\
BAŞLIKLARI \\
\end{tabular} \\
\hline \multirow{2}{*}{ Birey ve Toplum } & 5. Sinif & Çocuk Hakları & & \multirow{9}{*}{$\begin{array}{l}\text { Hariciye } \\
\text { Vekaleti }\end{array}$} \\
\hline & 6. Sinif & Sorunlarımın Çözümünü Biliyorum & & \\
\hline \multirow{4}{*}{ Kültür ve Miras } & 4. Sinif & Millî Kültür Ögelerimiz & & \\
\hline & 5. Sinif & Geçmişten Günümüze Kültürümüz & & \\
\hline & 6. Sinif & Destan ve Yazitlarda Türkler & & \\
\hline & 7. Sinif & Osmanlı'dan Kalan Mirasımız & & \\
\hline \multirow{4}{*}{ İnsanlar, Yerler ve Çevreler } & 4. Sinif & Çevremizde Neler Var? & & \\
\hline & 4. Sinif & Doğal Afetlere Hazır Olalım & & \\
\hline & 5. Sinif & Doğal Afetlerin Yaşamımıza Etkisi & & \\
\hline & 6. Sinif & Çevremizde Kimler Yaşıyor? & & \multirow{8}{*}{$\begin{array}{l}\text { Sihh1 ve İctimai } \\
\text { Muavenet }\end{array}$} \\
\hline Bilim, Teknoloji ve Toplum & 4. Sinif & Zarar Vermeden Kullanalım & & \\
\hline \multirow{2}{*}{ Üretim, Dağıtım ve Tüketim } & 4. Sinif & Tüketime Evet, İsrafa Hayır & & \\
\hline & 6. Sinıf & Vergilerimizle Aydınlık Yarınlara & & \\
\hline Etkin Vatandaşlık & 6. Sinif & Yöneticilerimiz ve Biz & & \\
\hline \multirow{3}{*}{ Küresel Bağlantılar } & 4. Sinif & Dünya Farklılıklarla Güzel & & \\
\hline & 5. Sinif & Ortak Mirasımız & & \\
\hline & 6. Sinif & Kültürümüze Sahip Çıkalım & & \\
\hline
\end{tabular}

Tablo 9 incelendiğinde Duyarlılık değerinin; Birey ve Toplum, Kültür ve Miras, İnsanlar, Yerler ve Çevreler, Bilim, Teknoloji ve Toplum, Üretim, Dağıtım ve Tüketim, Etkin Vatandaşlık ve Küresel Bağlantılar öğrenme alanlarında aktarılmaya çalışıldığı düşünülmektedir.

Birey ve Toplum öğrenme alanında 5.sınıfta Çocuk Hakları başlığı altında "Çocuk olarak haklarından yararlanmaya ve bu hakların ihlal edildiği durumlara örnekler verir." kazanımı üzerinden değerin aktarılmaya çalışıldığı düşünülmektedir. Konu anlatım metninde çocuk haklarının korunması ve ihlallerin önlenmesi için kamu kurumlarına, sivil toplum kuruluşlarına ve çocuk haklarına duyarlı insanlara görevler düştüğü belirtilerek değerin doğrudan aktarılmaya çalışıldığı düşünülmektedir. 6.sınıfta Sorunlarımın Çözümünü Biliyorum başlığı altında "Bir soruna getirilen çözümlerin hak, sorumluluk ve özgürlükler temelinde olması gerektiğini savunur." kazanımı üzerinden değerin aktarılmaya çalışıldığ d düşünülmektedir. Konu anlatım metninde Birleşmiş Milletler Çocuklara Yardım Fonu'ndan yapılan alıntıda Neden çocuk haklarına ihtiyaç vardır? Sorusuna verilen cevap olarak "Biz çocuklar masum ve duyarlıyız." cümlesi doğrultusunda değerin aktarılmaya çalış1ldığ düşünülmektedir.

Kültür ve Miras öğrenme alanında 4.sınıfta Millî Kültür Ögelerimiz başlığı altında "Ailesi ve çevresindeki millî kültürü yansıtan ögeleri araştırarak örnekler verir." kazanımı üzerinden değerin aktarılmaya çalışıldığı düşünülmektedir. Konu anlatım metninde aktarılan müze gezisinde kültürel mirasımıza karşı duyarlı olmamız gerektiği aktarılarak değerin aktarılmaya çalışıldığ düşünülmektedir. 5.sinıfta Geçmişten Günümüze Kültürümüz başlığı altında "Günlük yaşamdaki kültürel unsurların tarihî gelişimini değerlendirir." kazanımı üzerinden değerin dolaylı olarak aktarılmaya çalışıldığ 1 düşünülmektedir. 6.sınıfta Destan ve Yazıtlarda Türkler başlığı altında "Orta Asya'da kurulan ilk Türk devletlerinin coğrafi, siyasal, ekonomik ve kültürel özelliklerine ilişkin çıkarımlarda bulunur." kazanımı üzerinden değerin dolaylı olarak aktarılmaya çalışıldığı düşünülmektedir. 7.sınıfta da Osmanlı'dan Kalan Mirasımız başlığı altında "Osmanlı kültür, sanat ve estetik anlayışına örnekler verir." kazanımı üzerinden değerin dolaylı olarak aktarılmaya çalışıldığı düşünülmektedir.

İnsanlar, Yerler ve Çevreler öğrenme alanında 4.sınıfta Çevremizde Neler Var? başlığı altında "Yaşadığl çevredeki doğal ve beşerî unsurları ayırt eder." kazanımı üzerinden değerin aktarılmaya çalışıldığı düşünülmektedir. Konu anlatım metninde doğadaki varlıklara ve doğal 
çevreye duyarlı olmamız gerektiğini belirtilerek değerin doğrudan aktarılmaya çalışıldığ düşünülmektedir. 4.sınıfta Doğal Afetlere Hazır Olalım başlığı altında "Doğal afetlere yönelik gerekli hazırlıkları yapar.” kazanımı üzerinden değerin aktarılmaya çalışıldığı düşünülmektedir. Konu anlatım metninde sel baskınlarını önlemek için özellikle doğal çevreye duyarlı olunması gerektiği belirtilerek değerin doğrudan aktarılmaya çalış1ldığı düşünülmektedir. 5.sınıfta Doğal Afetlerin Yaşamımıza Etkisi başlığı altında "Doğal afetlerin toplum hayatı üzerine etkilerini örneklerle açıklar." kazanımı üzerinden değerin dolaylı olarak aktarılmaya çalışıldığı düşünülmektedir. 6.sınıfta da Çevremizde Kimler Yaşıyor? başlığı altında "Dünyanın farklı doğal ortamlarındaki insan yaşantılarından yola çıkarak iklim özellikleri hakkında çıkarımlarda bulunur." kazanımı üzerinden değerin dolaylı olarak aktarılmaya çalışıldığı düşünülmektedir.

Bilim, Teknoloji ve Toplum öğrenme alanında 4.sınıfta Zarar Vermeden Kullanalım başlığı altında "Teknolojik ürünleri kendisine, başkalarına ve doğaya zarar vermeden kullanır." kazanımı üzerinden değerin dolaylı olarak aktarılmaya çalışıldığı düşünülmektedir.

Üretim, Dağıtım ve Tüketim öğrenme alanında 4.sınıfta Tüketime Evet, İsrafa Hayır başlığı altında "Çevresindeki kaynakları israf etmeden kullanır." kazanımı üzerinden değerin aktarılmaya çalışıldığ 1 düşünülmektedir. Konu anlatım metninde israfla ilgili düzenlene yarışmalardan bahsedilerek bu yarışmaların öğrencileri israfın zararları hakkında düşünmeye teşvik ettiği ve onlarda israfla ilgili farkındalık ve duyarlılık meydana getirdiği belirtilerek değerin doğrudan aktarılmaya çalışıldığ 1 düşünülmektedir. 6.sınıfta da Vergilerimizle Aydınlık Yarınlara başlığı altında "Vatandaşlık sorumluluğu ve ülke ekonomisine katkısı açısından vergi vermenin gereğini ve önemini savunur. " kazanımı üzerinden değerin dolaylı olarak aktarılmaya çalışıldığı düşünülmektedir.

Etkin Vatandaşlık öğrenme alanında 6.sınıfta Yöneticilerimiz ve Biz başlığı altında "Yönetimin karar alma sürecini etkileyen unsurları analiz eder." kazanımı üzerinden değerin aktarılmaya çalışıldığ 1 düşünülmektedir. Konu anlatım metninde kamuoyunun istek ve taleplerine duyarlı olmadan alınan siyasi kararların ya uzun ömürlü olamayacağı ya da bu kararların etkisi zayıf olacağı belirtilerek değerin aktarılmaya çalışıldığ 1 düşünülmektedir.

Küresel Bağlantılar öğrenme alanında 4.sınıfta Dünya Farklılıklarla Güzel başlı̆ğ altında "Farklı kültürlere saygı gösterir." kazanımı üzerinden, 5.sınıfta Ortak Mirasımız başlığı altında "Çeşitli ülkelerde bulunan ortak miras ögelerine örnekler verir. " kazanımı üzerinden değerin dolaylı olarak aktarılmaya çalışıldığı düşünülmektedir. 6.sınıfta Kültürümüze Sahip Çıkalım başlığı altında "Popüler kültürün, kültürümüz üzerindeki etkilerini sorgular." kazanımı üzerinden değerin aktarılmaya çalışıldığ1 düşünülmektedir. Konu anlatım içeriğinde Popüler Kültür Türkçeyi Zayıflatıyor başlıklı haber metninde Feyza Hepçilingirler'in dil konusundaki yanlış kullanımları eleştirdiği ve bu konuda yetkili mercileri ve medyayı yeterli duyarlılığ göstermediklerini söylediği aktarılarak değerin aktarılmaya çalışıldığı düşünülmektedir.

Vatandaş İçin Medeni Bilgiler kitapları Duyarlılık değeri açısından incelendiğinde; kitabın 2.cildinde Hariciye Vekaleti bölümünde Vekaletin Görevleri başlığı altında görevler üzerinden, Sihhı ve İctimai Muavenet (Sağlık ve Sosyal Yardım) başlığı altında da sosyal yardım üzerinden değerin aktarılmaya çalışıldığı düşünülmektedir. Kitabın 1.cildinde duyarlılık değerinin aktarılmaya çalış1ldığı düşünülmemektedir. 


\section{Dürüstlük Değeri:}

Tablo 10: 2018 Sosyal Bilgiler Öğretim Programı ile Vatandaş İçin Medeni Bilgiler Kitabının 1.

ve 2. Cildinde Dürüstlük Değerinin Kazandırıldığı Konuların Dağglımları

\begin{tabular}{|c|c|c|c|c|}
\hline $\begin{array}{l}\text { ÖĞRENME } \\
\text { ALANLARI }\end{array}$ & SINIFLAR & $\begin{array}{l}\text { DÜRÜSTLÜK } \\
\text { KAZANDIRILDIĞI KONULARININ }\end{array}$ & $\begin{array}{l}\text { CILT } 1 \text { KONU } \\
\text { BAŞLIKLARI }\end{array}$ & $\begin{array}{l}\text { CİLT } 2 \text { KONU } \\
\text { BAȘLIKLARI }\end{array}$ \\
\hline \multirow{3}{*}{ Kültür ve Miras } & 4. Sinif & $\begin{array}{lll}\text { Bir Kahramanlık } & \text { Destanı: } & \text { Millî } \\
\text { Mücadele } & & \\
\end{array}$ & \multirow{3}{*}{$\begin{array}{l}\text { Hürriyetin } \\
\text { Muhtelif } \\
\text { Şekilleri }\end{array}$} & \multirow{3}{*}{$\begin{array}{l}\text { Bankaların } \\
\text { Yaptığ } 1 \\
\text { Muameleler }\end{array}$} \\
\hline & 5. Sinif & Uygarlıkları Öğreniyorum & & \\
\hline & 6. Sinif & İslamiyet ve Türkler & & \\
\hline Teknoloji & 4. Sinif & Zarar Vermeden Kullanalım & \multirow{3}{*}{$\begin{array}{l}\text { Meslek Nas1l } \\
\text { İntihap olunur }\end{array}$} & \multirow{3}{*}{$\begin{array}{l}\text { Vekâletlerde } \\
\text { Birbirine } \\
\text { Benziyen } \\
\text { Teșkilât }\end{array}$} \\
\hline Toplum & 5. Sinif & Bilimsel Etik & & \\
\hline $\begin{array}{l}\text { Üretim, Dağıtım ve } \\
\text { Tüketim }\end{array}$ & 7. Sinif & İşinin Ehli İnsan Yetiştirmek & & \\
\hline
\end{tabular}

Tablo 10 incelendiğinde Dürüstlük değerinin; Kültür ve Miras, Bilim, Teknoloji ve Toplum, Üretim, Dağıtım ve Tüketim, öğrenme alanlarında aktarılmaya çalışıldığı düşünülmektedir.

Kültür ve Miras öğrenme alanında 4.sınıfta Bir Kahramanlık Destanı: Millî Mücadele başlığı altında "Millî Mücadele kahramanlarının hayatlarından hareketle Millî Mücadele'nin önemini kavrar." kazanımı üzerinden değerin aktarılmaya çalışıldığı düşünülmektedir. Konu anlatım metninde Doğu Cephesi ve Kâzım Karabekir anlatılırken evlat edindiği çocuklarda en çok göze çarpan şeyin dürüstlük, doğru sözlülük olduğu belirtilerek değerin aktarılmaya çalışıldığ 1 düşünülmektedir. 5.sınıfta Uygarlıkları Öğreniyorum başlığ1 altında "Somut kalıntılarından yola çıkarak Anadolu ve Mezopotamya uygarlıklarının insanlık tarihine önemli katkılarını fark eder." kazanımı üzerinden değerin aktarılmaya çalışıldığı düşünülmektedir. Konu anlatım metninde Hipokrat yeminine yer verilerek mesleğimi dürüstlük ve onurla yapacağıma namusum ve şerefim üzerine yemin ederim sözleriyle değerin aktarılmaya çalış1ldığ 1 düşünülmektedir. 6.sınıfta da İslamiyet ve Türkler başlığı altında "Türklerin İslamiyet'i kabulleri ile birlikte siyasi, sosyal ve kültürel alanlarda meydana gelen değişimleri fark eder." kazanımı üzerinden değerin aktarılmaya çalış1ldığ 1 düşünülmektedir. Konu anlatım metninde anlatılırken Türkistan'a gelen müslüman tüccarların dürüstlükleri ile örnek oluşturdukları bunun da Türklerin İslamiyet'e olan ilgisini arttığ1 vurgulanarak değerin doğrudan aktarılmaya çalışıldığı düşünülmektedir.

Bilim, Teknoloji ve Toplum öğrenme alanında 4.sınıfta Zarar Vermeden Kullanalım başlığı altında "Teknolojik ürünleri kendisine, başkalarına ve doğaya zarar vermeden kullanır." kazanımı üzerinden değerin aktarılmaya çalışıldığ 1 düşünülmektedir. Konu anlatım metninde teknolojiyi yanlış kullanan kişilerin yalnız kendilerine değil başka insanlara da zarar verebileceğine dikkat çekilmekte, 112 'yi arayarak bu merkezde çalışanları meşgul eden insanların dürüstlüğe aykırı bu hareketleriyle başka insanların hayatlarını tehlikeye attıkları belirtilerek değerin doğrudan aktarılmaya çalışıldığı düşünülmektedir. 5.sınıfta Bilimsel Etik başlığı altında "Yaptığı çalışmalarda bilimsel etiğe uygun davranır. " kazanımı üzerinden değerin dolaylı olarak aktarılmaya çalışıldığı düşünülmektedir.

Üretim, Dağıtım ve Tüketim öğrenme alanında da 7.sınıfta İşinin Ehli İnsan Yetiştirmek başlı̆̆1 altında "Tarih boyunca Türklerde meslek edindirme ve meslek etiği kazandırmada rol oynayan kurumları tanır" kazanımı üzerinden dolaylı olarak değerin aktarılmaya çalışıldığı düşünülmektedir.

Vatandaş İçin Medeni Bilgiler kitapları Dürüstlük değeri açısından incelendiğinde; kitabın 1.cildinde Hürriyetin Muhtelif (Çeşitli)Şekilleri başlığı altında bireysel mülkiyet üzerinden, Meslek Nasıl İntihap (Seçilir) olunur ve Yapılır başlığı altında meslek hakkında bilgiler üzerinden değerin aktarılmaya çalışıldığ 1 düşünülmektedir. Kitabın 2.cildinde ise; Bankaların Yaptığ1 Muameleler (İşlemler) başlığı altında avanslar üzerinden ve Vekâletlerde Birbirine Benziyen Teşkilât başlığ altında teftişin önemi üzerinden değerin aktarılmaya çalışıldığı düşünülmektedir. 
10. Estetik Değeri:

Tablo 11: 2018 Sosyal Bilgiler Öğretim Programı ile Vatandaş İçin Medeni Bilgiler Kitabının 1. ve 2. Cildinde Estetik Değerinin Kazandırıldığı Konuların Dağılımları

\begin{tabular}{|c|c|c|c|c|}
\hline ÖĞRENME ALANLARI & SINIFLAR & $\begin{array}{l}\text { ESTETIK DEĞERINIIN } \\
\text { KAZANDIRILDIĞI KONULAR }\end{array}$ & $\begin{array}{lr}\text { CİLT } & 1 \\
\text { KONU } & \\
\text { BAŞLIKLARI }\end{array}$ & $\begin{array}{l}\text { CILTT } \\
\text { KONU } \\
\text { BAŞLIKLARI }\end{array}$ \\
\hline Birey ve Toplum & 6. Sinif & Kültürümüzle Yaşıyor ve Gelişiyoruz & \multirow{3}{*}{ Millet } & \multirow{6}{*}{$\begin{array}{l}\text { Tahsil } \\
\text { Dereceleri }\end{array}$} \\
\hline \multirow{4}{*}{ Kültür ve Miras } & 5. Sinif & Çevremizdeki Güzellikler & & \\
\hline & 5. Sinif & Kültürel Zenginliğimiz & & \\
\hline & 6. Sinif & Destan ve Yazitlarda Türkler & \multirow{3}{*}{ Türk Dili } & \\
\hline & 7. Sinif & Osmanlıdan Kalan Mirasımız & & \\
\hline $\begin{array}{l}\text { Üretim, Dağıtım ve } \\
\text { Tüketim }\end{array}$ & 6. Sinif & Mesleğimi Seçiyorum & & \\
\hline
\end{tabular}

Tablo 11 incelendiğinde Estetik değerinin; Birey ve Toplum, Kültür ve Miras ve Üretim, Dağıtım ve Tüketim, öğrenme alanlarında aktarılmaya çalışıldığı düşünülmektedir.

Birey ve Toplum öğrenme alanında 6.sınıfta Kültürümüzle Yaşıyor ve Gelişiyoruz başlığ1 altında "Sosyal, kültürel ve tarihî bağların toplumsal birlikteliğin oluşmasındaki yerini ve rolünü analiz eder." kazanımı üzerinden değerin aktarılmaya çalıșıldığı düşünülmektedir. Konu anlatım metninde sanatın tanımı üzerinden "Sanat, toplumsal estetik anlayışını geliştirir." cümlesi ile değerin aktarılmaya çalışıldığ 1 düşünülmektedir.

Kültür ve Miras öğrenme alanında 5.sınıfta Çevremizdeki Güzellikler başlığı altında “Çevresindeki doğal varlıklar ile tarihî mekânları, nesneleri ve eserleri tanıtır." kazanımı üzerinden ve Kültürel Zenginliğimiz başlığı altında "Ülkemizin çeşitli yerlerinin kültürel özellikleri ile yaşadı̆̆ çevrenin kültürel özelliklerini karşılaştırarak bunlar arasındaki benzer ve farklı unsurları belirler." kazanımı üzerinden değerin dolaylı olarak aktarılmaya çalışıldığı düşünülmektedir. 6.sınıfta Destan ve Yazıtlarda Türkler başlığı altında "Orta Asya'da kurulan ilk Türk devletlerinin coğrafi, siyasal, ekonomik ve kültürel özelliklerine ilişkin çıkarımlarda bulunur." kazanımı üzerinden değerin aktarılmaya çalışıldığı düşünülmektedir. Konu anlatım metninde Hun sanatının temelinin konargöçer yaşam tarzına dayandığı, bu nedenle yerleşik hayata özgü olan tapınak, saray, kale gibi sanat yapılarına Hun sanatında pek rastlanmadığı ve bunun yerine yaşadıkları göçebe hayata uygun ama estetik değeri yüksek eşyalar yaparak kullandıkları belirtilerek değerin doğrudan aktarılmaya çalışıldığ 1 düşünülmektedir. 7.sınıfta da Osmanlıdan Kalan Mirasımız başlığı altında "Osmanlı kültür, sanat ve estetik anlayıșına örnekler verir. " kazanımı üzerinden değerin aktarılmaya çalıșıldığı düşünülmektedir. Konu anlatım metninde Osmanlı sanatında mimari eserlerin ön plana çıktığı, Osmanlı mimarlarının yaptı̆̆ 1 camilerin, medreselerin, köprülerin, hamamların, imarethanelerin çağının üstün estetik anlayışını yansıttığı vurgulanarak değerin doğrudan aktarılmaya çalışıldığı düşünülmektedir.

Üretim, Dağıtım ve Tüketim öğrenme alanında 6.sınıfta Mesleğimi Seçiyorum başlı̆ğ altında "Illgi duyduğu mesleklerin gerektirdiği kişilik özelliklerini, becerileri ve ĕgitim sürecini araştırır." kazanımı üzerinden değerin aktarılmaya çalışıldığı düşünülmektedir. Konu anlatım metninde insanların ilgi, yetenek ve değerleri çok farklı olduğu, aynı zamanda toplumun farklı ihtiyaçlarının bulunduğu ve bunun sonucunda mesleklerin ortaya çıktığ 1 ve çeşitlendiği belirtilerek mesleki özellikler arasında da estetik değerinin doğrudan aktarılmaya çalışıldığ 1 düşünülmektedir.

Vatandaş İçin Medeni Bilgiler kitapları Estetik değeri açısından incelendiğinde; kitabın 1.cildinde Millet bölümünde Türk Dili başlığı altında Türk dilinin zenginliği üzerinden ve bağl1lık başlığı altında estetik değerinin özellikleri üzerinden aktarılmaya çalışıldığı düşünülmektedir. 2.cildinde ise; Tahsil Dereceleri başlı̆̆ı altında güzel sanatlar akademisi üzerinden değerin aktarılmaya çalışıldığı düşünülmektedir. 


\section{Eşitlik Değeri:}

Tablo 12: 2018 Sosyal Bilgiler Öğretim Programı ile Vatandaş İçin Medeni Bilgiler Kitabının 1. ve 2. Cildinde Kazandırıldığı Eşitlik Değerinin Konuların Dağılımları

\begin{tabular}{|c|c|c|c|c|}
\hline ÖĞRENME ALANLARI & SINIFLAR & $\begin{array}{l}\text { EŞİTLİK DEĞERİNIN } \\
\text { KAZANDIRILDIĞI } \\
\text { KONULAR }\end{array}$ & $\begin{array}{l}\text { CİLT } 1 \text { KONU } \\
\text { BAŞLIKLARI }\end{array}$ & $\begin{array}{lr}\text { CILT } & 2 \\
\text { KONU } \\
\text { BAŞLIKLARI } \\
\end{array}$ \\
\hline Bilim, Teknoloji ve Toplum & 7. Sinif & Özgür Düşüncenin Bilime Katkıs1 & \multirow{2}{*}{$\begin{array}{l}\text { Demokrasi } \\
\text { Prensipini } \\
\text { Muhteviyat1 }\end{array}$} & \\
\hline \multirow{3}{*}{ Kültür ve Miras } & 6. Sinif & Destan ve Yazıtlarda Türkler & & \\
\hline & 6. Sinif & İslamiyet'in Doğuşu ve Değişim & \multirow{2}{*}{$\begin{array}{l}\text { Vatandaşa Karş1 } \\
\text { Devletin Vazifeleri }\end{array}$} & \\
\hline & 6. Sinif & İslamiyet ve Türkler & & \\
\hline \multirow{8}{*}{ Etkin Vatandaşlık } & 4. Sinif & Ben Çocuğum, Haklarımla Varım & \multirow{2}{*}{ Ordu Mekteptir } & \\
\hline & 5. Sinif & Temel Haklarımızı Öğrenelim & & \\
\hline & 6. Sinif & Nas1l bir yönetim? & \multirow{2}{*}{ Müsavat } & \\
\hline & 6. Sinif & Hayatın İcinde Demokrasi & & \\
\hline & 6. Sinif & Kadın ve Toplum & \multirow{2}{*}{ İntihap } & \\
\hline & 7. Sinif & Demokrasi Serüveni & & \\
\hline & 7. Sinif & Atatürk'ten Milletimize Armağan & \multirow{2}{*}{ Vergi } & \\
\hline & 7. Sinif & Cumhuriyetimi Seviyorum & & \\
\hline
\end{tabular}

Tablo 12 incelendiğinde Eşitlik değerinin; Bilim, Teknoloji ve Toplum ile Etkin Vatandaşlık öğrenme alanlarında aktarılmaya çalışıldığı düşünülmektedir.

Bilim, Teknoloji ve Toplum öğrenme alanında 7.sınıfta Özgür Düşüncenin Bilime Katkıs1 başlı̆̆ 1 altında “Özgür düşüncenin bilimsel gelişmelere katkısını değerlendirir." kazanımı üzerinden değerin aktarılmaya çalışıldığı düşünülmektedir. Konu anlatım metninde 1789 yılında Fransız düşünürlerin de etkisiyle meydana gelen Fransız İhtilali ile Fransa'nın yönetim biçiminin değiştiği, tüm dünyaya yayılan "hürriyet, adalet, kardeşlik, eşitlik" gibi kavramların özgür düşüncenin gelişmesine katkı sağladığı belirtilerek değerin doğrudan aktarılmaya çalışıldığı düşünülmektedir.

Kültür ve Miras öğrenme alanında 6.sınıfta Destan ve Yazıtlarda Türkler başlığı altında "Orta Asya'da kurulan ilk Türk devletlerinin coğrafi, siyasal, ekonomik ve kültürel özelliklerine ilişkin çıkarımlarda bulunur." kazanımı üzerinden değerin aktarılmaya çalışıldığı düşünülmektedir. Konu anlatım metninde Kök Türk Yazıtlarında töresini kaybetmiş ulusun yok olacağı hatırlatılarak kağanlardan töreye uygun davranmaları istenmiş ve törenin değişmeyen hükümlerinin adalet, iyilik ve eşitlik olduğu belirtilerek değerin doğrudan aktarılmaya çalışıldığı düşünülmektedir. İslamiyet'in Doğuşu ve Değişim başlığı altında "İslamiyet' in ortaya çıkışını ve beraberinde getirdiği değiş̧imleri yorumlar." kazanımı üzerinden değerin aktarılmaya çalışıldığı düşünülmektedir. Konu anlatım metninde 10 Aralık 1948'de kabul edilen İnsan Hakları Evrensel Beyannamesi'nde yer alan yaşama hakk1, eşitlik, özgürlük ve adalet kavramlarının 1400 yıl önce Veda Hutbesinde vurgulandığ aktarılarak değerin aktarılmaya çalışıldığı düşünülmektedir. İslamiyet ve Türkler başlı̆g altında da "Türklerin Íslamiyet'i kabulleri ile birlikte siyasi, sosyal ve kültürel alanlarda meydana gelen değişimleri fark eder.” kazanımı üzerinden değerin aktarılmaya çalışıldığı düşünülmektedir. Konu anlatım metninde Abbasiler Dönemi'nde uygulanan eşitlik ve adalet politikalarının etkisiyle Türklerin kısa zamanda ve kalabalık gruplar hâlinde İslamiyet'i kabul ettikleri aktarılarak değerin doğrudan aktarılmaya çalışıldığı düşünülmektedir.

Etkin Vatandaşlık öğrenme alanında 4.sınıfta Ben Çocuğum, Haklarımla Varım başlığ altında "Çocuk olarak sahip olduğu haklara örnekler verir." kazanımı üzerinden değerin aktarılmaya çalışıldığı düşünülmektedir. Konu anlatım metninde önemli çocuk haklarından birinin de eşitlik olduğu vurgulanarak değerin doğrudan aktarılmaya çalışıldığı düşünülmektedir. 5.sınıfta Temel Haklarımızı Öğrenelim başlı̆̆ altında "Temel hakları ve bu hakları kullanmanın önemini açıklar." kazanımı üzerinden değerin aktarılmaya çalışıldığı düşünülmektedir. Konu anlatım metninde temel hak ve özgürlüklerin korunduğu ve kullanıldığı bir toplumun bireylerinin huzur ve 
güven içinde yaşadığı ve bu tür toplumlarda adalet ve eşitliğin insanlar arasında daha kolay sağlandığı belirtilerek değerin doğrudan aktarılmaya çalışıldığı düşünülmektedir. 6.sınıfta Nasıl bir yönetim? başlı̆̆ altında "Demokrasinin temel ilkeleri açısından farklı yönetim biçimlerini karşılaş̧ırır." kazanımı üzerinden değerin aktarılmaya çalışıldığı düşünülmektedir. Konu anlatım metninde Eşitliğin, tüm vatandaşların kanunlar önünde aynı haklara sahip olması olduğu aktarılarak değerin aktarılmaya çalışıldığ 1 düşünülmektedir. Hayatın İçinde Demokrasi başlığı altında "Toplumsal hayatımızda demokrasinin önemini açıklar." kazanımı üzerinden değerin aktarılmaya çalış1ldığ düşünülmektedir. Konu anlatım metninde Demokratik toplumsal yaşamın eşitlik, hak ve adalet üzerine kurulu olduğu belirtilerek değerin aktarılmaya çalışıldığı düşünülmektedir. Kadın ve Toplum başlığı altında da "Türk tarihinden ve güncel örneklerden yola çıkarak toplumsal hayatta kadına verilen değeri fark eder. " kazanımı üzerinden değerin dolaylı olarak aktarılmaya çalıșıldığı düşünülmektedir. 7.sınıfta Demokrasi Serüveni başlı̆g 1 altında "Demokrasinin ortaya çıkışını, gelişim evrelerini ve günümüzde ifade ettiği anlamları açıklar." kazanımı üzerinden değerin aktarılmaya çalışıldığı düşünülmektedir. Konu anlatım metninde demokratik yönetimlerde bireyler arasında eşitlik prensibinin olduğu aktarılarak değerin aktarılmaya çalışıldığı düşünülmektedir. Atatürk'ten Milletimize Armağan başlığı altında "Atatürk'ün Türk demokrasisinin gelişimine katkılarını açıklar." kazanımı üzerinden değerin aktarılmaya çalışıldığı düşünülmektedir. Konu anlatım metninde kadınlara seçme ve seçilme haklarının verilmesi ile demokrasinin önemli değerlerinden eşitlik ve katılım ilkeleri gerçekleştirilmiş olduğu belirtilerek değer doğrudan kazandırılmaya çalışılmaktadır. Cumhuriyetimi Seviyorum başlığı altında da "Türkiye Cumhuriyeti Devleti' nin temel niteliklerini toplumsal hayattaki uygulamalarla ilişkilendirir. " kazanımı üzerinden değerin aktarılmaya çalışıldığı düşünülmektedir. Konu anlatım metninde sosyal devlet anlayışının vatandaşların hak ve özgürlüklerini koruyan eşitlik ilkesini benimseyen devlet anlayışı olduğu belirtilerek değerin doğrudan aktarılmaya çalışıldığı düşünülmektedir.

Vatandaş İçin Medeni Bilgiler kitapları Eşitlik değeri açısından incelendiğinde; kitabın 1.cildinde Demokrasi Prensipini Muhteviyatı (Kapsam) bölümünde Demokrasi Prensipinin Bariz Vasıfları başlı̆̆ı altında demokrasinin özellikleri üzerinden, Demokrasiye Muhalif (Aykırı) Asri (Çağdaş) Cereyanlar (Olaylar) başlı̆̆ 1 altında kişi ve sinıflar üzerinden, Vatandaşa Karşı Devletin Vazifeleri başlığı altında devlet üzerinden değerin aktarılmaya çalışıldığ 1 düşünülmektedir. Ayrıca değer Müsavat (Eşitlik) başlığı altında eşitliğin amacı üzerinden değerin doğrudan aktarılmaya çalışıldığ düşünülmektedir. İntihap başlığı altında da cumhuriyetin siyasi rejimi üzerinden, Vergi

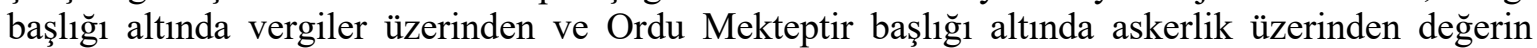
aktarılmaya çalışıldığı düşünülmektedir. Kitabın 2. cildinde ise; değerin aktarılmaya çalışıldığ1 düşünülmemektedir. 
12. Özgürlük Değeri:

Tablo 13: 2018 Sosyal Bilgiler Öğretim Programı ile Vatandaş İçin Medeni Bilgiler Kitabının 1. ve 2. Cildinde Özgürlük Değerinin Kazandırıldığı Konuların Dağılımları

\begin{tabular}{|c|c|c|c|c|}
\hline ÖĞRENME ALANLARI & SINIFLAR & $\begin{array}{l}\text { ÖZGÜRLÜK } \quad \text { DEĞERINIIN } \\
\text { KAZANDIRILDIĞI KONULAR }\end{array}$ & $\begin{array}{l}\text { CİLT } 1 \text { KONU } \\
\text { BAŞLIKLARI }\end{array}$ & $\begin{array}{l}\text { CILTT } \\
\text { KONU } \\
\text { BAŞLIKLARI }\end{array}$ \\
\hline \multirow{2}{*}{ Birey ve Toplum } & 6. Sinif & Sorunlarımın Çözümünü Biliyorum & \multirow{4}{*}{$\begin{array}{l}\text { Millet } \\
\text { Türk Milletinin } \\
\text { Mütaleası }\end{array}$} & \\
\hline & 7. Sinif & İletişim Özgürlüğü & & \\
\hline \multirow{2}{*}{ Kültür ve Miras } & 7. Sinif & İnsanı Yaşat Ki Devlet Yaşasın & & \\
\hline & 7. Sinif & Avrupa'da Uyanış & & \\
\hline İnsanlar, Yerler ve Çevreler & 7. Sinif & $\begin{array}{l}\text { Yerleşme ve Seyahat Özgürlüğ̈̈m } \\
\text { Var }\end{array}$ & \multirow{4}{*}{ Devlet } & \\
\hline Bilim, Teknoloji ve Toplum & 7. Sinif & Özgür Düşüncenin Bilime Katkısı & & \\
\hline Üretim, Dağıtım ve Tüketim & 6. Sinif & Vergilerimizle Aydınlık Yarınlara & & \\
\hline \multirow{8}{*}{ Etkin Vatandaşlık } & 4. Sinif & Sorumluluk Üstleniyorum & & \\
\hline & 4. Sinif & Özgürlük ve Bağımsızlık & \multirow{4}{*}{$\begin{array}{l}\text { Hürriyet } \\
\text { İçtimai } \\
\text { Medeni } \\
\text { Hürriyet } \\
\end{array}$} & \\
\hline & 5. Sinif & Temel Haklarımızı Öğrenelim & & \\
\hline & 6. Sinif & Nasıl Bir Yönetim? & & \\
\hline & 6. Sinif & Hayatın İçinde Demokrasi & & \\
\hline & 6. Sinif & Haklarımın Bilincindeyim & \multirow{3}{*}{$\begin{array}{l}\text { Hürriyetin } \\
\text { Muhtelif } \\
\text { Şekilleri }\end{array}$} & \\
\hline & 6. Sinif & Kadın ve Toplum & & \\
\hline & 7. Sinif & Demokrasi Serüveni & & \\
\hline
\end{tabular}

Tablo 13 incelendiğinde Özgürlük değerinin; Birey ve Toplum, Kültür ve Miras, İnsanlar, Yerler ve Çevreler, Bilim, Teknoloji ve Toplum, Üretim, Dağıtım ve Tüketim ve Etkin Vatandaşlık öğrenme alanlarında aktarılmaya çalışıldığı düşünülmektedir.

Birey ve Toplum öğrenme alanında 6.sınıfta Sorunlarımın Çözümünü Biliyorum başlığ altında "Bir soruna getirilen çözümlerin hak, sorumluluk ve özgürlükler temelinde olması gerektiğini savunur." kazanımı üzerinden değerin aktarılmaya çalış1ldığ1 düşünülmektedir. Konu anlatım metninde özgürlüklerin sınırsız olmadığı bu nedenle insanların evde, okulda, sokakta veya trafikte istedikleri gibi davranamayacakları belirtilerek değerin doğrudan aktarılmaya çalışıldığ 1 düşünülmektedir. 7.sınıfta İletişim Özgürlüğü başlı̆̆ 1 altında "İletişim araçlarından yararlanırken hakların kullanır ve sorumluluklarını yerine getirir." kazanımı üzerinden değerin aktarılmaya çalış1ldığı düşünülmektedir. Konu anlatım metninde iletişim araçlarını kullanırken sahip olduğumuz hak ve özgürlüklerimizin Anayasamız tarafından güvence altına alındığı ve bize ait hak ve özgürlüklerin tüm bireyler içinde geçerli olduğu belirtilerek değerin doğrudan aktarılmaya çalışıldığ1 düşünülmektedir.

Kültür ve Miras öğrenme alanında 7.sınıfta İnsanı Yaşat Ki Devlet Yaşasın başlığı altında “Osmanlı Devleti'nin fetih siyasetini örnekler üzerinden analiz eder." kazanımı üzerinden değerin aktarılmaya çalışıldığ düşünülmektedir. Konu anlatım metninde İstimâlet siyasetinin dört aşamada gerçekleştiği bunların: fetih öncesi hazırlık, fetih sonrası halkın alıştırılması, adil yönetim anlayışı, halka tanınan din, dil ve kültürel özgürlükler olduğu belirtilerek değerin doğrudan aktarılmaya çalışıldığı düşünülmektedir. Avrupa'da Uyanış başlığı altında "Avrupa'daki gelişmelerle bağlantılı olarak Osmanlı Devleti'ni değişime zorlayan süreçleri kavrar." kazanımı üzerinden değerin aktarılmaya çalışıldığı düşünülmektedir. Konu anlatım metninde Fransız İhtilali sonucunda tüm dünyada milliyetçilik, eşitlik, özgürlük kavramları önem kazandığı aktarılarak değerin aktarılmaya çalışıldığı düşünülmektedir.

İnsanlar, Yerler ve Çevreler öğrenme alanında 7.sınıfta Yerleşme ve Seyahat Özgürlüğüm Var başlığı altında "Temel haklardan yerleşme ve seyahat özgürlüğünün kısitlanması halinde ortaya çıkacak olumsuz durumlara örnekler gösterir. ” kazanımı üzerinden değerin aktarılmaya çalışıldığ1 düşünülmektedir. Konu anlatım metninde seyahat özgürlüğüne getirilecek kısıtlamaların yalnızca bu özgürlügün kullanımına değil bireyin çalışma, eğitim, sağlık alanlarındaki özgürlükleri ile sosyal, 
ekonomik hak ve özgürlüklerinin de kısıtlanmasına yol açabileceği ve bu yüzden seyahat özgürlüğünün kısıtlanmasının diğer özgürlüklerimizi de etkileyebileceği vurgulanarak değerin doğrudan aktarılmaya çalışıldığı düşünülmektedir.

Bilim, Teknoloji ve Toplum öğrenme alanında 7.sınıfta Özgür Düşüncenin Bilime Katkısı başlı̆̆ altında "Özgür düşüncenin bilimsel gelişmelere katkısını değerlendirir. " kazanımı üzerinden değerin aktarılmaya çalışıldığı düşünülmektedir. Konu anlatım metninde Avrupa'da Aydınlanma Çağı'nın önemli düşünürlerinden Montesquieu'ye (Monteskü) göre "Düşünce özgürlüğü en önemli özgürlüktür. " cümlesiyle değerin aktarılmaya çalışıldığı düşünülmektedir.

Üretim, Dağıtım ve Tüketim öğrenme alanında 6.sınıfta Vergilerimizle Aydınlık Yarınlara başlığı altında "Vatandaşlık sorumluluğu ve ülke ekonomisine katkısı açısından vergi vermenin gereğini ve önemini savunur" kazanımı üzerinden değerin aktarılmaya çalışıldığı düşünülmektedir. Konu anlatım metninde devletimizin hak ve özgürlüklerimizi güvence altına aldığı, bizim de devlete karş1 sorumluluklarımızın olduğu ve bu sorumluluklardan birisinin de vergi sorumluluğumuz olduğu tüm hak, özgürlük ve sorumluluklarımızın Anayasamızda yer aldığı belirtilerek değerin aktarılmaya çalışıldığı düşünülmektedir.

Etkin Vatandaşlık öğrenme alanında 4.sınıfta Sorumluluk Üstleniyorum başlığı altında "Aile ve okul yaşamındaki söz ve eylemlerinin sorumluluğunu alır." kazanımı üzerinden değerin aktarılmaya çalışıldığı düşünülmektedir. Konu anlatım metninde özgürlüklerin sınırsız olmadığı bu nedenle insanların evde, okulda, sokakta veya trafikte istedikleri gibi davranamayacakları belirtilerek değerin aktarılmaya çalışıldığı düşünülmektedir. Özgürlük ve Bağımsızlık başlığı altında "Ülkesinin bă̆ımsızlı̆̆ ile bireysel özgürlüğ̈̈ arasındaki ilişkiyi açıklar." kazanımı üzerinden değerin aktarılmaya çalışıldığı düşünülmektedir. Konu anlatım metninde Ülkemizin bağımsızlığını ve bireysel özgürlüklerimizi 15 Temmuz'da darbecilere karşı cesaretle direnenlere borçlu olduğumuz hatırlatılarak değerin doğrudan aktarılmaya çalışıldığı düşünülmektedir. 5.sınıfta Temel Haklarımızı Öğrenelim başlığı altında "Temel hakları ve bu hakları kullanmanın önemini açıklar." kazanımı üzerinden değerin aktarılmaya çalışıldığı düşünülmektedir. Konu anlatım metninde insanların her türlü dış etkiden bağımsız olarak kendi isteğine ve düşüncesine göre karar vermesine özgürlük denildiği belirtilerek değerin aktarılmaya çalışıldığı düşünülmektedir. 6. sınıfta Nasıl Bir Yönetim? başlı̆̆ 1 altında "Demokrasinin temel ilkeleri açısından farklı yönetim biçimlerini karşılaştırır." kazanımı üzerinden değerin aktarılmaya çalışıldığı düşünülmektedir. Konu anlatım metninde özgürlüğü insanların anayasal ve yasal sınırlar içinde kalmak şartıyla başkalarının özgürlüğünü engellemeden istediklerini düşünebilmesi ve istediklerine inanabilmesi şeklinde tanımlayarak değerin aktarılmaya çalıșıldığı düşünülmektedir. Hayatın İçinde Demokrasi başlığ1 altında “Toplumsal hayatımızda demokrasinin önemini açıklar." kazanımı üzerinden değerin aktarılmaya çalışıldığı düşünülmektedir. Konu anlatım metninde toplumsal düzenin korunması için insanların birbirlerinin hak ve özgürlüklerine sayg1 duyması, kurallara uyması ve adil olması gerektiği vurgulanarak değerin aktarılmaya çalışıldığ düşünülmektedir. Haklarımın Bilincindeyim başlığı altında "Türkiye Cumhuriyeti'nin etkin bir vatandaşı olarak hak ve sorumluluklarının anayasal güvence altında olduğunu açılklar." kazanımı üzerinden değerin aktarılmaya çalışıldığı düşünülmektedir. Konu anlatım metninde hak ve özgürlüklerimizin ihlali ile ilgili bir sorunla karşılaştığımızda demokratik haklarımızı kullanıp gerekli kurumlara başvurarak ya da görevli kişilerle iletişime geçerek sorunların üstesinden gelebileceğimiz aktarılarak değerin aktarılmaya çalışıldığ düşünülmektedir. Kadın ve Toplum başlığ 1 altında da "Türk tarihinden ve güncel örneklerden yola çıkarak toplumsal hayatta kadına verilen değeri fark eder." kazanımı üzerinden değerin aktarılmaya çalışıldığı düşünülmektedir. Konu anlatım metninde toplumda hak ve özgürlüklerin eşitlik ve adalet ilkeleri çerçevesinde herkese tanınması ve uygulanması gerektiği belirtilerek değerin aktarılmaya çalışıldığı düşünülmektedir. 7.sınıfta Demokrasi Serüveni başlığ1 altında "Demokrasinin ortaya çıkışını, gelişsim evrelerini ve günümüzde ifade ettiği anlamları açıklar." kazanımı üzerinden değerin aktarılmaya çalışıldığı düşünülmektedir. Konu anlatım 
metninde özgürlüklerimizin başkalarının hak ve özgürlüklerine zarar vermemesi ve kanunlara aykırı olmaması gerektiği belirtilerek değerin aktarılmaya çalışıldığı düşünülmektedir.

Vatandaş İçin Medeni Bilgiler kitapları Özgürlük değeri açısından incelendiğinde; kitabın 1. cildinde Millet bölümünde Türk Milletinin Mütaleası (Görüşü) başlığı altında görüşler üzerinden, Devlet başlığ 1 altında özgürlükler üzerinden, Hürriyet bölümünde İçtimai (Toplumsal) ve Medeni

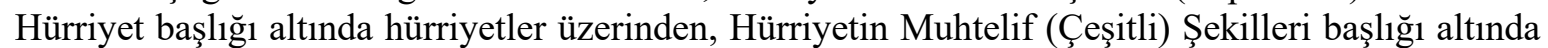
hürriyet şekilleri üzerinden değerin aktarılmaya çalışıldığı düşünülmektedir. Değerin özellikle Hürriyet bölümü altında aktarılmaya çalışıldığı düşünülmektedir. Kitabın 2. Cildinde ise; değerin aktarılmaya çalışıldığı düşünülmemektedir.

\section{Saygı Değeri:}

Tablo 14: 2018 Sosyal Bilgiler Öğretim Programı ile Vatandaş İçin Medeni Bilgiler Kitabının 1. ve 2. Cildinde Saygı Değerinin Kazandırıldığı Konuların Dağılımları

\begin{tabular}{|c|c|c|c|c|}
\hline $\begin{array}{l}\text { ÖĞRENME } \\
\text { ALANLARI }\end{array}$ & SINIFLAR & $\begin{array}{ll}\text { SAYGI } & \text { DEĞERİNIN } \\
\text { KAZANDIRILDIĞI KONULAR }\end{array}$ & $\begin{array}{lcl}\text { CİLT } & 1 & \text { KONU } \\
\text { BAŞLIKLARI } & \\
\end{array}$ & $\begin{array}{l}\text { CİLT } 2 \text { KONU } \\
\text { BAŞLIKLARI }\end{array}$ \\
\hline \multirow{4}{*}{ Birey ve Toplum } & 4. Sinif & $\begin{array}{l}\text { Farkındayım, } \quad \text { Farklılıklara } \\
\text { Saygılıyım }\end{array}$ & Medeni His & \multirow{3}{*}{$\begin{array}{l}\text { Reisicümhurun } \\
\text { mes'uliyeti }\end{array}$} \\
\hline & 5. Sinif & Hak ve Sorumluluklarımız & Cumhuriyet & \\
\hline & 6. Sinif & Ön Yargıları Kırıyorum & \multirow{2}{*}{$\begin{array}{l}\text { Demokrasiye } \\
\text { Asri Cereyanlar }\end{array}$} & \\
\hline & 7. Sinif & İletişim Özgürlüğü & & \multirow{2}{*}{$\begin{array}{ll}\text { Kanunlara } & \\
\text { Riayet } & \text { ve } \\
\text { hürmet } & \end{array}$} \\
\hline \multirow[t]{2}{*}{ Kültür ve Miras } & 4. Sinif & Millî Kültür Ögelerimiz & İlk Hak, İlk Vazife & \\
\hline & 5. Sinif & Kültürümüzü Tanıyalım & \multirow{2}{*}{$\begin{array}{l}\text { Hoş Görmeklik, } \\
\text { Taassupsuzluk }\end{array}$} & \multirow{2}{*}{ Devlet Şürası } \\
\hline \multirow{3}{*}{ Etkin Vatandaşlık } & 6. Sinif & Nasıl Bir Yönetim? & & \\
\hline & 6. Sinif & Yöneticilerimiz ve Biz & Kamuoyu & \multirow{2}{*}{ Memurlar } \\
\hline & 6. Sinif & Hayatın İçinde Demokrasi & \multirow{3}{*}{$\begin{array}{l}\text { Meslek Nasil İntihap } \\
\text { Olunur ve Yapılır }\end{array}$} & \\
\hline \multirow{2}{*}{$\begin{array}{l}\text { Küresel } \\
\text { Bağlantılar }\end{array}$} & 4. Sinif & Dünya Farklılıklarla Güzel & & \multirow{2}{*}{ Maarif } \\
\hline & 7. Sinif & İnsanları Nasıl Tanıyoruz? & & \\
\hline
\end{tabular}

Tablo 14 incelendiğinde Sayg1 değerinin; Birey ve Toplum, Kültür ve Miras, Etkin Vatandaşlık ve Küresel Bağlantılar öğrenme alanlarında aktarılmaya çalışıldığı düşünülmektedir.

Birey ve Toplum öğrenme alanında 4.sınıfta Farkındayım, Farklılıklara Saygılıyım başlığı altında "Diğer bireylerin farklı özelliklerini saygı ile karşılar." kazanımı üzerinden değerin aktarılmaya çalışıldığı düşünülmektedir. Konu anlatım metninde sağlıklı insan ilişkilerinin ancak farklılıklara saygıyla kurulabileceği ve farklılıkları hor görmeye ve değiştirmeye hakkımız olmadığını bilerek insanların inançlarını ve düşüncelerini saygı ile karşılamamamız gerektiği aktarılarak değerin aktarılmaya çalışıldığı düşünülmektedir. 5.sınıfta Hak ve Sorumluluklarımız

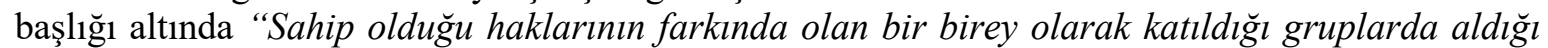
rollerin gerektirdiği görev ve sorumluluklara uygun davranır." kazanımı üzerinden değerin aktarılmaya çalışıldığ 1 düşünülmektedir. Konu anlatım metninde evimizi temiz ve düzenli tutmanın, ev işlerini yaparken aile büyüklerimize yardımcı olmanın, aile bireylerine sevgi ve saygı göstermenin sorumluluklarımızdan bazıları olduğu belirtilerek değerin aktarılmaya çalışıldığı düşünülmektedir. 6.sınıfta Ön Yargıları Kırıyorum başlığı altında "Toplumda uyum içerisinde yaşayabilmek için farklılıklara yönelik ön yargıları sorgular." kazanımı üzerinden değerin aktarılmaya çalışıldığı düşünülmektedir. Konu anlatım metninde birbirini tanımayan, empati kuramayan, farklılıklara sayg1 duymayan bireylerde başkalarına karşı ön yargılar oluştuğu aktarılarak değerin aktarılmaya çalışıldığı düşünülmektedir. 7.sınıfta da İletişim Özgürlüğü başlığı altında "İletişim araçlarından yararlanırken haklarını kullanır ve sorumluluklarını yerine getirir." kazanımı üzerinden değerin aktarılmaya çalışıldığı düşünülmektedir. Konu anlatım metninde tarafsız olmanın ve özel hayata saygılı olmanın medya ve basın yayın kuruluşlarının uyması gereken ilkelerden olduğu belirtilerek değerin aktarılmaya çalışıldığı düşünülmektedir. 
Kültür ve Miras öğrenme alanında 4.sınıfta Millî Kültür Ögelerimiz başlığı altında "Ailesi ve çevresindeki millî kültürü yansıtan ögeleri araştırarak örnekler verir." kazanımı üzerinden değerin aktarılmaya çalışıldığı düşünülmektedir. Konu anlatım metninde bayramların akrabalarımıza ve çevremizdeki insanlara karşı olan sevgimizi ve saygımızı göstermemize firsat sunduğu belirtilerek değerin aktarılmaya çalışıldığı düşünülmektedir. 5.sınıfta Kültürümüzü Tanıyalım başlığı altında "Kültürel ögelerin, insanların bir arada yaşamasındaki rolünü analiz eder." kazanımı üzerinden değerin aktarılmaya çalışıldığı düşünülmektedir. Konu anlatım metninde birlik ve beraberliğimizin, sevgi ve saygı duygularının bayramlarda güçlendiği aktarılarak değerin aktarılmaya çalışıldığı düşünülmektedir.

Etkin Vatandaşlık öğrenme alanında 6.sınıfta Nasıl Bir Yönetim? başlığı altında "Demokrasinin temel ilkeleri açısından farkl yönetim biçimlerini karşılaştırır. " kazanımı üzerinden değerin aktarılmaya çalışıldığı düşünülmektedir. Konu anlatım metninde Çoğulculuğun tanımının, farklı görüşlere, anlayışlara, inanışlara saygı gösterilmesi olduğu belirtilerek değerin aktarılmaya çalışıldığı düşünülmektedir. Yöneticilerimiz ve Biz başlığı altında "Türkiye Cumhuriyeti Devleti'nde yasama, yürütme ve yargı güçleri arasındaki ilişsiyi açılar." kazanımı üzerinden değerin aktarılmaya çalışıldığı düşünülmektedir. Konu anlatım metninde trafikte saygı, hayatımıza saygı konusunu medya ile desteklenebileceği belirtilerek değerin aktarılmaya çalışıldığı düşünülmektedir. Hayatın İçinde Demokrasi başlığı altında da "Toplumsal hayatımızda demokrasinin önemini açıklar." kazanımı üzerinden değerin aktarılmaya çalışıldığı düşünülmektedir. Konu anlatım metninde toplumsal düzenin korunması için insanların birbirlerinin hak ve özgürlüklerine sayg1 duyması, kurallara uyması ve adil olması gerektiği belirtilerek değerin aktarılmaya çalışıldığı düşünülmektedir.

Küresel Bağlantılar öğrenme alanında 4.sınıfta Dünya Farklılıklarla Güzel başlığı altında "Farklı kültürlere saygı gösterir." kazanımı üzerinden değerin aktarılmaya çalışıldığı düşünülmektedir. Konu anlatım metninde insanın kendisinden farklı olana saygılı olursa karşısındaki de ona sayg1 duyacağı vurgulanarak değerin aktarılmaya çalışıldığ İnsanları Nasıl Tanıyoruz? başlığı altında "Çeşitli kültürlere yönelik kalıp yargıları sorgular." kazanımı üzerinden değerin aktarılmaya çalışıldığı düşünülmektedir. Konu anlatım metninde kalıp yargılardan kurtulmamızın yolunun farklılıkları tanımak ve saygılı olmak olduğu belirtilerek değerin aktarılmaya çalış1ldığ 1 düşünülmektedir.

Vatandaş İçin Medeni Bilgiler kitapları Saygı değeri açısından incelendiğinde; kitabın 1.cildinde Millet bölümünde Medeni His başlığı altında Türk milleti üzerinden, Cumhuriyet başlı̆̆ altında yöneticiler üzerinden, Demokrasiye Muhalif (Aykıı) Asri (Çağdaş) Cereyanlar (olaylar) başıı̆̆ altında demokrasiye aykırı akımlar üzerinden, İlk Hak, İlk Vazife (görev) başlığı altında devlet ve haklar üzerinden, Hürriyet bölümünde Hoş Görmeklik, Taassupsuzluk başlığı altında fikirler üzerinden, Hürriyet bölümünde Kamuoyu başlığı altında eleştiri ve tartışma üzerinden ve Meslek Nasıl İntihap Olunur ve Yapılır başlığı altında meslek erdemleri üzerinden değerin aktarılmaya çalışıldığı düşünülmektedir. Kitabın 2.cildinde ise; İcra Kuvvetleri bölümünde Reisicümhurun mes'uliyeti (Sorumluluk) başlığı altında milli sevgi ve saygı üzerinden, Kanun bölümünde Kanunlara Riayet (Uymak) ve hürmet (Saygı) başlığı altında yasalara uymak ve sayg1 göstermek üzerinden, Devlet Şürası bölümünde Daireler ve görevleri üzerinden, Memurlar bölümünde kolluk kuvvetlerine saygı üzerinden ve Maarif bölümünde öğretmene saygı üzerinden değerin doğrudan aktarılmaya çalışıldığı düşünülmektedir. 


\section{Sevgi Değeri:}

Tablo 15: 2018 Sosyal Bilgiler Öğretim Programı ile Vatandaş İçin Medeni Bilgiler Kitabının 1. ve 2. Cildinde Sevgi Değerinin Kazandırıldığı Konuların Dağılımları

\begin{tabular}{|c|c|c|c|c|}
\hline ÖĞRENME ALANLARI & SINIFLAR & $\begin{array}{lc}\text { SEVGI } & \text { DEĞERININ } \\
\text { KAZANDIRILDIĞI KONULAR }\end{array}$ & $\begin{array}{l}\text { CİLT } 1 \text { KONU } \\
\text { BAŞLIKLARI }\end{array}$ & $\begin{array}{l}\text { CILLT } 2 \text { KONU } \\
\text { BAȘLIKLARI }\end{array}$ \\
\hline \multirow{5}{*}{ Birey ve Toplum } & 4. Sinif & Onun Yerinde Olsaydım & \multirow{3}{*}{$\begin{array}{l}\text { Millet } \\
\text { Türk Dili }\end{array}$} & \multirow{3}{*}{$\begin{array}{l}\text { Hükümet } \\
\text { Teşkilatı } \\
\text { Başvekilin } \\
\text { İstifas1 }\end{array}$} \\
\hline & 5. Sinif & Hak ve Sorumluluklarımız & & \\
\hline & 6. Sinif & Değişen Rollerim & & \\
\hline & 6. Sinif & $\begin{array}{lll}\text { Kültürümüzle } & \text { Yaşıyor } & \text { ve } \\
\text { Gelişiyoruz } & & \end{array}$ & \multirow{3}{*}{$\begin{array}{l}\text { Hürriyet } \\
\text { Ferdi Hürriyet }\end{array}$} & \multirow{3}{*}{ Aile } \\
\hline & 7. Sinif & İletişimin Gücü & & \\
\hline \multirow{2}{*}{ Kültür ve Miras } & 4. Sinif & Millî Kültür Ögelerimiz & & \\
\hline & 5. Sinıf & Kültürümüzü Tanıyalım & \multirow{4}{*}{ Askerlik } & \multirow{4}{*}{ Milli Müdaafa } \\
\hline Dağıtım & 6. Sinif & Kaynaklarımız Kazanca Dönüşüyor & & \\
\hline Tüketim & 7. Sinif & Vakıf Demek, Medeniyet Demek & & \\
\hline Etkin Vatandaşlik & 4. Sinif & Özgürlük ve Bağımsızlık & & \\
\hline
\end{tabular}

Tablo 15 incelendiğinde Sevgi değerinin; Birey ve Toplum, Kültür ve Miras, Üretim, Dağıtım, Tüketim ve Etkin Vatandaşlık öğrenme alanlarında aktarılmaya çalışıldığı düşünülmektedir.

Birey ve Toplum öğrenme alanında 4.sınıfta Onun Yerinde Olsaydım başlığı altında "Kendisini farkl özelliklere sahip diğer bireylerin yerine koyar." kazanımı üzerinden değerin aktarılmaya çalışıldığı düşünülmektedir. Konu anlatım metninde her sınıfın bir yetim kardeşi olsun adı verilen proje ile öğrencilere değerler eğitimini vermeye çalışıldığ 1 ve bu sayede çocukların hoşgörüyü, sevgiyi ve empati kurmayı öğrendikleri belirtilerek değerin doğrudan aktarılmaya çalışıldığı düşünülmektedir. 5.sınıfta Hak ve Sorumluluklarımız başlığı altında "Sahip olduğu haklarının farkında olan bir birey olarak katıldı̆̆ gruplarda aldlğg rollerin gerektirdiği görev ve sorumluluklara uygun davranır." kazanımı üzerinden değerin aktarılmaya çalış1ldığ düşünülmektedir. Konu anlatım metninde beslenme ve barınma gibi fiziksel ihtiyaçlarımızla birlikte sevgi ve saygı gibi duygusal ihtiyaçlarımızı da ailemiz sayesinde karşıladığımız belirtilerek değerin doğrudan aktarılmaya çalışıldığı düşünülmektedir. 6.sınıfta Değişen Rollerim başlığı altında "Sosyal rollerin zaman içerisindeki değişimini inceler.” kazanımı üzerinden değerin aktarılmaya çalışıldığ düşünülmektedir. Konu anlatım metninde aile içi roller sevgi, saygı, dayanışma ve yardımseverlik duygularıyla yerine getirilmesi gerektiği aktarılarak değerin aktarılmaya çalışıldığı düşünülmektedir. Kültürümüzle Yaşıyor ve Gelişiyoruz başlığı altında "Sosyal, kültürel ve tarihî bağların toplumsal birlikteliğin oluşmasındaki yerini ve rolünü analiz eder." kazanımı üzerinden değerin aktarılmaya çalışıldığı düşünülmektedir. Konu anlatım metninde millet olarak tarih boyunca inancımızın ve kültürümüzün temel unsurları olan insan sevgisi, yardımlaşma ve adaleti yaşatmaya çalıştığımız belirtilerek değerin aktarılmaya çalışıldığı düşünülmektedir. 7.sınıfta da İletişimin Gücü başlığ altında "Bireysel ve toplumsal ilişkilerde olumlu iletişim yollarını kullanır." kazanımı üzerinden değerin aktarılmaya çalışıldığı düşünülmektedir. Konu anlatım metninde Anadolu insanının bazen konuşmak yerine renklerle, sembollerle, motiflerle duygu ve düşüncesini ifade ettiği ve İğne oyasıyla da sevgi, acı, pişmanlık, öfke, düş kırıklığı, mutluluk gibi duygularını dile getirdiği aktarılarak değerin aktarılmaya çalışıldığı düşünülmektedir.

Kültür ve Miras öğrenme alanında 4.sınıfta Millî Kültür Ögelerimiz başlığı altında "Ailesi ve çevresindeki millî kültürü yansıtan ögeleri araştırarak örnekler verir.” kazanımı üzerinden değerin aktarılmaya çalışıldığı düşünülmektedir. Konu anlatım metninde bayramların akrabalarımıza ve çevremizdeki insanlara karşı olan sevgimizi ve saygımızı göstermemize firsat sunduğu aktarılarak değerin aktarılmaya çalışıldığı düşünülmektedir. 5.sınıfta Kültürümüzü Tanıyalım başlığı altında "Kültürel ögelerin, insanların bir arada yaşamasındaki rolünü analiz eder." kazanımı üzerinden değerin aktarılmaya çalışıldığı düşünülmektedir. Konu anlatım metninde kültürü oluşturan unsurların 
bizlerin bir arada yaşamasını sağlamakta olduğu, inançlarımız, ortak değerlerimiz, bayrak ve vatan sevgimiz, bayramlarımız; kültürümüzü zenginleştirmekte ve millî birliğimizi güçlendirmekte olduğu aktarılarak değerin aktarılmaya çalış1ldığı düşünülmektedir.

Üretim, Dağıtım ve Tüketim öğrenme alanında 6.sınıfta Kaynaklarımız Kazanca Dönüşüyor başlığı altında "Ülkemizin kaynaklarıyla ekonomik faaliyetlerini ilişsilendirir. " kazanımı üzerinden değerin aktarılmaya çalışıldığı düşünülmektedir. Konu anlatım metninde toprağın hayatımızdaki yerini türkülerine yansıtan Âşık Veysel'in, vasiyetinde bizlere tabiat sevgisi dersi verdiği aktarılarak değerin aktarılmaya çalışıldığı düşünülmektedir. 7.sınıfta Vakıf Demek, Medeniyet Demek başlı̆g 1 altında "Kurumların ve sivil toplum kuruluşlarının çalı̧̧malarına ve sosyal yaşamdaki rollerine örnekler verir." kazanımı üzerinden değerin aktarılmaya çalışıldığı düşünülmektedir. Konu anlatım metninde vakıflardan yardım alan kişilerin sadece yardım gördüğü vakfa değil aynı zamanda ait olduğu topluma karşı da sevgi, saygı, bağlılık duyguları beslediği belirtilerek değerin aktarılmaya çalış1ldığ düşünülmektedir.

Etkin Vatandaşlık öğrenme alanında 4.sınıfta Özgürlük ve Bağımsızlık başlığı altında "Ülkesinin bağımsızlı̆̆ı ile bireysel özgürlüğü arasındaki ilişsiyi açıklar." kazanımı üzerinden değerin aktarılmaya çalışıldığı düşünülmektedir. Konu anlatım metninde vatanın bugünlere gelmesinde vatan sevgisi, kardeşlik duygusu ve bağımsızlık isteğinin etkili olduğu aktarılarak değerin aktarılmaya çalışıldığı düşünülmektedir.

Vatandaş İçin Medeni Bilgiler kitapları Sevgi değeri açısından incelendiğinde; kitabın 1.cildinde Millet bölümünde Türk Dili başlığı altında Türk diline olan sevgi üzerinden ve Hürriyet bölümünde Ferdi Hürriyet başlı̆̆ altında bireysel haklar üzerinden, Askerlik başlığı altında vatan ve arkadaşlık sevgisi üzerinden değerin aktarılmaya çalışıldığı düşünülmektedir. Kitabın 2.cildinde ise; Hükümet Teşkilatı bölümünde Başvekilin İstifası başlığı üzerinden, Aile başlı̆̆1 altında aile üzerinden ve Milli Müdaafa bölümünde ordu üzerinden değerin aktarılmaya çalışıldığı düşünülmektedir.

\section{Sorumluluk Değeri}

Tablo 16: 2018 Sosyal Bilgiler Öğretim Programı ile Vatandaş İçin Medeni Bilgiler Kitabının 1. ve 2. Cildinde Sorumluluk Değerinin Kazandırıldığı Konuların Dağılımları

\begin{tabular}{|c|c|c|c|c|}
\hline $\begin{array}{l}\text { ÖĞRENME } \\
\text { ALANLARI }\end{array}$ & SINIFLAR & $\begin{array}{l}\text { SORUMLULUK } \quad \text { DEĞERINIIN } \\
\text { KAZANDIRILDIĞI KONULAR }\end{array}$ & $\begin{array}{l}\text { CİLT } 1 \text { KONU } \\
\text { BAŞLIKLARI }\end{array}$ & $\begin{array}{l}\text { CİLT } 2 \text { KONU } \\
\text { BAŞLIKLARI }\end{array}$ \\
\hline \multirow{5}{*}{ Birey ve Toplum } & 4. Sinif & Onun Yerinde Olsaydım & Millet & Maarif \\
\hline & 5. Sinif & $\begin{array}{lll}\text { Sosyal } & \text { Bilgiler } & \text { Dersinden } \\
\text { Öğrendiklerimiz } & \\
\end{array}$ & Milli His & $\begin{array}{l}\text { Vekaletin } \\
\text { Vazifesi }\end{array}$ \\
\hline & 5. Sinif & Hak ve Sorumluluklarımız & Cumhuriyet & İcra Kuvvetleri \\
\hline & 6. Sinif & Sorunlarımın Çözümünü Biliyorum & \multirow{2}{*}{$\begin{array}{l}\text { Hükümdarlık, } \\
\text { Oligarşi }\end{array}$} & \multirow{2}{*}{$\begin{array}{l}\text { Reisicümhurun } \\
\text { mes'uliyeti }\end{array}$} \\
\hline & 7. Sinif & İletişim Özgürlüğü & & \\
\hline \multirow{4}{*}{$\begin{array}{l}\text { Üretim, Dağıtım ve } \\
\text { Tüketim }\end{array}$} & 4. Sinif & Ayağımızı Yorganımıza Göre Uzatalım & Hürriyet & \multirow{3}{*}{ Hükümet } \\
\hline & 5. Sinif & Yeni Fikirler Geliştirelim & \multirow{2}{*}{$\begin{array}{l}\text { Hürriyetin } \\
\text { Muhtelif } \\
\text { Şekilleri }\end{array}$} & \\
\hline & 6. Sinif & Vergilerimizle Aydınlık Yarınlara & & \\
\hline & 7. Sinif & Topraktan Üretir, Toprağ1 Yönetiriz & Eşitlik & \multirow{3}{*}{$\begin{array}{l}\text { Vekillerin } \\
\text { vazifeleri }\end{array}$} \\
\hline \multirow{6}{*}{ Etkin Vatandaşlik } & 4. Sinif & Sorumluluk Üstleniyorum & \multirow[b]{2}{*}{ Bağlılık } & \\
\hline & 4. Sinif & $\begin{array}{lll}\text { Eğitsel ve } & \text { Sosyal } & \text { Etkinliklere } \\
\text { Katıliyorum } & & \end{array}$ & & \\
\hline & 5. Sinif & Halka Hizmet Veren Kurumlar & \multirow{2}{*}{ Askerlik Vazifesi } & \multirow{2}{*}{$\begin{array}{l}\text { Hükümet } \\
\text { Teşkilatı }\end{array}$} \\
\hline & 5. Sinif & Yaşadığım Yerin Yönetimi & & \\
\hline & 6. Sinif & Haklarımın Bilincindeyim & \multirow{2}{*}{$\begin{array}{l}\text { Kumandanların } \\
\text { Umumi Hassaları }\end{array}$} & \multirow{2}{*}{ Aile } \\
\hline & 7. Sinif & Hakimiyet Milletindir! & & \\
\hline
\end{tabular}

Tablo 16 incelendiğinde Sorumluluk değerinin; Birey ve Toplum, Üretim, Dağıtım ve Tüketim ile Etkin Vatandaşlık öğrenme alanlarında aktarılmaya çalışıldığı düşünülmektedir. 
Birey ve Toplum öğrenme alanında 4.sınıfta Onun Yerinde Olsaydım başlığ 1 altında "Kendisini farkl özelliklere sahip diğer bireylerin yerine koyar." kazanımı üzerinden değerin aktarılmaya çalışıldığı düşünülmektedir. Konu anlatım metninde Bozköy İlkokulu 3A sınıfının 15 öğrencisi, öğretmenleri Narin Sözen Oruç öncülüğünde sosyal sorumluluk projeleri kapsamında Samsun'daki bir ilkokulda eğitim gören, hiç tanımadıkları yetim öğrenci E... N...'ye yardımda bulunmak için kampanya düzenledikleri belirtilerek değerin doğrudan aktarılmaya çalış1ldığ düşünülmektedir. 5.sınıfta Sosyal Bilgiler Dersinden Öğrendiklerimiz başlığı altında "Sosyal Bilgiler dersinin, Türkiye Cumhuriyeti'nin etkin bir vatandaşı olarak kendi gelişsimine katkısın fark eder. " kazanımı üzerinden değerin aktarılmaya çalışıldığı düşünülmektedir. Konu anlatım metninde vatandaşların bağlı olduğu devlete karşı sorumlulukları olduğu gibi devletin de vatandaşlara sağladığı haklar olduğu, haklarını ve sorumluluklarını bilen ve bunlara göre hareket eden kişilerin etkin birer vatandaş olacağ 1 aktarılarak değerin aktarılmaya çalışıldığ düşünülmektedir. Hak ve Sorumluluklarımız başlı̆̆ altında "Sahip olduğu haklarının farkında olan bir birey olarak katıldı̆̆ gruplarda aldığı rollerin gerektirdiği görev ve sorumluluklara uygun davranır. ” kazanımı üzerinden değerin aktarılmaya çalışıldığı düşünülmektedir. Konu anlatım metninde haklarımızı kullanırken yerine getirmemiz gereken görev ve sorumlulukların olduğu, bireylerin toplum içinde üzerlerine düşen sorumlulukları yerine getirmekle yükümlü olduğu belirtilerek değerin aktarılmaya çalışıldığı düşünülmektedir. 6.sınıfta Sorunlarımın Çözümünü Biliyorum başlığı altında "Bir soruna getirilen çözümlerin hak, sorumluluk ve özgürlükler temelinde olması gerektiğini savunur." kazanımı üzerinden değerin dolaylı olarak aktarılmaya çalışıldığı düşünülmektedir. 7.sınıfta da İletişim Özgürlüğü başlığı altında "İletişim araçlarından yararlanırken haklarını kullanır ve sorumluluklarını yerine getirir." kazanımı üzerinden değerin aktarılmaya çalışıldığ düşünülmektedir. Konu anlatım metninde iletişimle ilgili bir sorunla karşılaştığımızda haklarımızın ve sorumluluklarımızın neler olduğunu bilmenin çok önemli olduğu belirtilerek değerin aktarılmaya çalış1ldığ 1 düşünülmektedir.

Üretim, Dağıtım ve Tüketim öğrenme alanında 4.sınıfta Ayağımızı Yorganımıza Göre Uzatalım başlığı altında "Kendine ait örnek bir bütçe oluşturur." kazanımı üzerinden değerin aktarılmaya çalışıldığı düşünülmektedir. Konu anlatım metninde sorumluluk duygusuyla hareket ederek zorunlu ihtiyaçlarımıza öncelik vermemiz gerektiği vurgulanarak değerin aktarılmaya çalışıldığ1 düşünülmektedir. 5.sınıfta Yeni Fikirler Geliştirelim başlığ üretim, dağıtım ve tüketime dayalı yeni fikirler geliştirir." kazanımı üzerinden değerin aktarılmaya çalışıldığı düşünülmektedir. Konu anlatım metninde proje hazırlama döngüsü anlatılırken bu projenin bir iş fikri olabileceği gibi sosyal sorumluluk projesi de olabileceği ve sosyal sorumluluk projeler toplumsal sorunların çözümü için geliştirildiği belirtilerek değerin aktarılmaya çalışıldığ düşünülmektedir. 6.sınıfta Vergilerimizle Aydınlık Yarınlara başlığı altında "Vatandaşlık sorumluluğu ve ülke ekonomisine katkısı açısından vergi vermenin gereğini ve önemini savunur." kazanımı üzerinden değerin aktarılmaya çalışıldığı düşünülmektedir. Konu anlatım metninde devletimiz hak ve özgürlüklerimizi güvence altına aldığı, bizim de devlete karşı sorumluluklarımızın olduğu ve bu sorumluluklardan birisi de vergi sorumluluğu olduğu belirtilerek değerin aktarılmaya çalışıldığ1 düşünülmektedir. 7.sınıfta da Topraktan Üretir, Toprağ1 Yönetiriz başlığ1 altında "Üretimde ve yönetimde toprağın önemini geçmişten ve günümüzden örneklerle açıklar." kazanımı üzerinden değerin aktarılmaya çalışıldığı düşünülmektedir. Konu anlatım metninde tımar sahibinin kanunlara uyduğu ve devlete sorumluluklarını yerine getirdiği sürece toprağ 1 işletmeye devam ettiğ aktarılarak değerin aktarılmaya çalışıldığı düşünülmektedir.

Etkin Vatandaşlık öğrenme alanında 4.sınıfta Sorumluluk Üstleniyorum başlığı altında "Aile ve okul yaşamındaki söz ve eylemlerinin sorumluluğunu alır." kazanımı üzerinden değerin aktarılmaya çalışıldığ 1 düşünülmektedir. Konu anlatım metninde ailede günlük hayatın düzenli şekilde yürümesi için bizlerin de yerine getirmemiz gereken sorumluluklarımız olduğu aktarılarak değerin aktarılmaya çalışıldığı düşünülmektedir. Eğitsel ve Sosyal Etkinliklere Katılıyorum başlığ 
altında “Okul yaşamında gerekli gördüğ̈̈ eğitsel sosyal etkinlikleri önerir.” kazanımı üzerinden değerin aktarılmaya çalışıldığ 1 düşünülmektedir. Konu anlatım metninde öğrencilerin okullarında çeşitli amaçlarla topluluklar kurdukları ve sorumluluk üstlenmeyi davranış hâline getirerek toplumsal hayata daha özgür ve etkin bireyler olarak katıldıkları belirtilerek değerin aktarılmaya çalışıldığ düşünülmektedir. 5.sınıfta Halka Hizmet Veren Kurumlar başlı̆̆1 altında "Bireysel ve toplumsal ihtiyaçlar ile bu ihtiyaçların karşılanması için hizmet veren kurumları ilişkilendirir." kazanımı üzerinden değerin dolaylı olarak aktarılmaya çalışıldığı düşünülmektedir. Yaşadığım Yerin Yönetimi başlı̆̆ altında "Yaşadı̆̆ yerin yönetim birimlerinin temel görevlerini açıklar." kazanımı üzerinden değerin aktarılmaya çalışıldığı düşünülmektedir. Konu anlatım metninde Bakanların görevlerini yerine getirirken bireysel olarak sorumluluk alanlarıla ilgili karar alabildikleri gibi bir araya gelip Bakanlar Kurulu olarak da ülke yönetimiyle ilgili kararlar alabildikleri belirtilerek değer aktarılma çalışılmaktadır. 6.sınıfta Haklarımın Bilincindeyim başlığı altında "Türkiye Cumhuriyeti'nin etkin bir vatandaşı olarak hak ve sorumluluklarının anayasal güvence altında olduğunu açılklar." kazanımı üzerinden değerin aktarılmaya çalışıldığ 1 düşünülmektedir. Konu anlatım metninde temel haklar ve sorumlulukların Anayasa ile güvence altına alındı̆̆ı, bu yönüyle temel hakların ve sorumlulukların korunmasında en etkili gücün devlet olduğu vurgulanarak değerin aktarılmaya çalışıldığ düşünülmektedir. 7.sınıfta da Hakimiyet Milletindir! başlığ 1 altında "Demokrasinin uygulanma süreçlerinde karşılaşılan sorunları analiz eder. " kazanımı üzerinden değerin aktarılmaya çalışıldığı düşünülmektedir. Konu anlatım metninde okulda kurallara uymanın, düzenli bir öğrenci olmanın, derslere ait görevleri yapmanın okuldaki sorumluluklar arasında yer alığı aktarılarak değerin aktarılmaya çalışıldığı düşünülmektedir.

Vatandaş İçin Medeni Bilgiler kitapları Sorumluluk değeri açısından incelendiğinde; kitabın 1.cildinde Millet bölümünde Milli His başlı̆̆ 1 altında milli duygular üzerinden, Cumhuriyet bölümünde millet üzerinden ve Hükümdarlık, Oligarşi başlığı altında yönetim sistemi üzerinden, Hürriyet bölümünde Hürriyetin Muhtelif (Çeşitli) Şekilleri başlığ 1 altında ticaret üzerinden, Eşitlik başlı̆̆ı üzerinden anayasa üzerinden, Bağlılık başlığı altında yükümlülükler üzerinden, Askerlik Vazifesi bölümünde Kumandanların Umumi (Genel) Hassaları (Özellikleri) başlığı altında görevler üzerinden değerin aktarılmaya çalış1ldığı düşünülmektedir. Kitabın 2.cildinde ise; Maarif bölümünde Vekaletin Vazifesi başlığı altında görevler üzerinden, İcra Kuvvetleri bölümünde Reisicümhurun mes'uliyeti (Sorumluluk) başlığı altında sorumluluk üzerinden, Hükümet bölümünde Vekillerin vazifeleri başlığı altında görevler üzerinden, Hükümet Teşkilatı bölümünde ve Aile başlığı altında sorumluluk değerinin aktarılmaya çalışıldığı düşünülmektedir.

\section{Tasarruf Değeri:}

Tablo 17: 2018 Sosyal Bilgiler Öğretim Programı ile Vatandaş İçin Medeni Bilgiler Kitabının 1. ve 2. Cildinde Tasarruf Değerinin Kazandırıldığı Konuların Dağılımları

\begin{tabular}{|c|c|c|c|c|}
\hline ÖĞRENME ALANLARI & SINIFLAR & $\begin{array}{l}\text { TASARRUF } \\
\text { KAZANDIRILDIĞI KONULARININ }\end{array}$ & $\begin{array}{lr}\text { CILT } & 1 \\
\text { KONU } & \\
\text { BAŞLIKLARI } \\
\end{array}$ & $\begin{array}{lr}\text { CILT } & 2 \\
\text { KONU } & \\
\text { BAȘLIKLARI } \\
\end{array}$ \\
\hline İnsanlar, Yerler ve Çevreler & 4. Sinif & Doğal Afetlere Hazır Olalım & \multirow{2}{*}{$\begin{array}{l}\text { Kadınların } \\
\text { Intihap } \\
\text { Selahiyetleri }\end{array}$} & \multirow[b]{2}{*}{ Bankalar } \\
\hline Bilim, Teknoloji ve Toplum & 4. Sinif & Zarar Vermeden Kullanalım & & \\
\hline \multirow{3}{*}{ Üretim, Dağıtım ve Tüketim } & 4. Sinif & Ayağımızı Yorganımıza Göre Uzatalım & İş Bölümü Fikri & \multirow{3}{*}{$\begin{array}{ll}\text { Sanayi } & \text { ve } \\
\text { Maadin } & \\
\text { Bankas1 } & \\
\end{array}$} \\
\hline & 4. Sinif & Tüketime Evet, İsrafa Hayır & Vergi & \\
\hline & 6. Sinif & Nitelikli İnsan, Güçlü Türkiye & Vergi Kaideleri & \\
\hline
\end{tabular}

Tablo 17 incelendiğinde Tasarruf değerinin; İnsanlar, Yerler ve Çevreler, Bilim, Teknoloji ve Toplum ile Üretim, Dağıtım ve Tüketim öğrenme alanlarında aktarılmaya çalışıldığı düşünülmektedir.

İnsanlar, Yerler ve Çevreler öğrenme alanında 4.sınıfta Doğal Afetlere Hazır Olalım başlığı altında "Doğal afetlere yönelik gerekli hazırlıkları yapar." kazanımı üzerinden değerin aktarılmaya 
çalışıldığı düşünülmektedir. Konu anlatım metninde afet esnasında mahsur kalınırsa enerjiyi tasarruflu kullanmak için hareketlerimizi kontrol etmemiz gerektiği belirtilerek değerin aktarılmaya çalışıldığ düş̧ünülmektedir.

Bilim, Teknoloji ve Toplum öğrenme alanında 4.sınıfta Zarar Vermeden Kullanalım başlığı altında "Teknolojik ürünleri kendisine, başkalarına ve doğaya zarar vermeden kullanır." kazanımı üzerinden değerin aktarılmaya çalışıldığı düşünülmektedir. Konu anlatım metninde teknoloji firmalarının ürettikleri ürünlerin yanlış kullanımını önlemek amacıyla çeşitli önlemler aldığı, bu önlemlerin başında kullanım kılavuzları geldiği ve bu kılavuzda da enerji tasarrufu için önerilerin bulunduğu belirtilerek değerin aktarılmaya çalışıldığı düşünülmektedir.

Üretim, Dağıtım ve Tüketim öğrenme alanında 4.sınıfta Ayağımızı Yorganımıza Göre Uzatalım başlığı altında "Kendine ait örnek bir bütçe oluşturur." kazanımı üzerinden değerin aktarılmaya çalışıldığı düşünülmektedir. Konu anlatım metninde yapılan harcama sonunda artan paramızı harcamayıp tasarruf etmemiz gerektiği vurgulanarak değerin doğrudan aktarılmaya çalışıldığı düşünülmektedir. Tüketime Evet, İsrafa Hayır başlığı altında "Çevresindeki kaynakları israf etmeden kullanır. " kazanımı üzerinden değerin aktarılmaya çalışıldığı düşünülmektedir. Konu anlatım metninde su tasarrufuna yönelik davranışları hayatımız boyunca sürecek alışkanlıklar hâline getirmemiz gerektiği ve elektrik tasarrufunun ailedeki herkesi ilgilendiren bir konu olduğu belirtilerek değerin aktarılmaya çalışıldığı düşünülmektedir. 6.sınıfta da Nitelikli İnsan, Güçlü Türkiye başlığ 1 altında "Nitelikli insan gücünün Türkiye ekonomisinin gelişimindeki yerini ve önemini analiz eder." kazanımı üzerinden değerin aktarılmaya çalışıldığı düşünülmektedir. Konu anlatım metninde nitelikli insanların tasarruflu kişiler olduğu belirtilerek değerin doğrudan aktarılmaya çalışıldığı düşünülmektedir.

Vatandaş İçin Medeni Bilgiler kitapları Tasarruf değeri açısından incelendiğinde; kitabın 1.cildinde; Kadınların İntihap Selahiyetleri (Seçme Haklan) anlatılırken İş Bölümü Fikri başlığ1 altında kadınların tutumlu olduğu düşüncesi üzerinden ve Vergi bölümünde Vergi Kaideleri başlığ 1 altında değerin aktarılmaya çalışıldığı düşünülmektedir. Kitabın 2.cildinde ise; Bankalar bölümünde Sanayi ve Maadin (maden) Bankası konusunda kazanma üzerinden değerin aktarılmaya çalışıldığı düşünülmektedir.

\section{Vatanseverlik Değeri:}

Tablo 18: 2018 Sosyal Bilgiler Öğretim Programı ile Vatandaş İçin Medeni Bilgiler Kitabının 1. ve 2. Cildinde Vatanseverlik Değerinin Kazandırıldığı Konuların Dağılımları

\begin{tabular}{|c|c|c|c|c|}
\hline ÖĞRENME ALANLARI & SINIFLAR & $\begin{array}{l}\text { VATANSEVERLIKK DEĞERININ } \\
\text { KAZANDIRILDIĞI KONULAR }\end{array}$ & $\begin{array}{|lr|}\text { CILT } & 1 \\
\text { KONU } & \\
\text { BAŞLIKLARI } \\
\end{array}$ & \begin{tabular}{|l} 
CÍLT 2 KONU \\
BAŞLIKLARI \\
\end{tabular} \\
\hline Birey ve Toplum & 5. Sinif & Hak ve Sorumluluklarımız & \multirow{4}{*}{ Millet } & Anayasa \\
\hline \multirow{2}{*}{ Kültür ve Miras } & 4. Sinif & $\begin{array}{l}\text { Bir Kahramanlık Destanı: } \\
\text { Mücadele }\end{array}$ & & \multirow{2}{*}{$\begin{array}{l}\text { Türkiye Büyük } \\
\text { Millet Meclisi }\end{array}$} \\
\hline & 5. Sinıf & Kültürümüzü Tanıyalım & & \\
\hline \multirow{2}{*}{ Üretim, Dağıtım ve Tüketim } & 6. Sinif & Mesleğimi Seçiyorum & & \multirow{2}{*}{ Siyasi F1kralar } \\
\hline & 7. Sinif & Topraktan Üretir, Toprağ1 Yönetiriz & \multirow{5}{*}{ Türk Yurdu } & \\
\hline \multirow{4}{*}{ Etkin Vatandaşlik } & 4. Sinif & Özgürlük ve Bağımsızlık & & \multirow{2}{*}{ Maliye } \\
\hline & 6. Sinif & Hayatın İçinde Demokrasi & & \\
\hline & 7. Sinif & Atatürk'ten Milletimize Armağan & & \multirow{2}{*}{\begin{tabular}{|l|} 
Vilayetlerde \\
Maliye \\
Teskilat1
\end{tabular}} \\
\hline & 7. Sinif & Hakimiyet Milletindir! & & \\
\hline
\end{tabular}

Tablo 18 incelendiğinde Vatanseverlik değerinin; Birey ve Toplum, Kültür ve Miras, Üretim, Dağıtım ve Tüketim ile Etkin Vatandaşlık öğrenme alanlarında aktarılmaya çalışıldığı düşünülmektedir. 
Birey ve Toplum öğrenme alanında 5.sınıfta Hak ve Sorumluluklarımız başlı̆g altında "Sorumluluk sahibi bir birey olarak bilinçli tüketici davranışları sergiler." kazanımı üzerinden değerin aktarılmaya çalışıldığı düşünülmektedir. Konu anlatım metninde Mustafa Kemal Atatürk'ün "Vatanını en çok seven, görevini en iyi yapandır." sözü ile değerin aktarılmaya çalışıldığı düşünülmektedir.

Kültür ve Miras öğrenme alanında 4.sınıfta Bir Kahramanlık Destanı: Millî Mücadele başlığı altında "Millî Mücadele kahramanlarının hayatlarından hareketle Millî Mücadele'nin önemini kavrar." kazanımı üzerinden değerin aktarılmaya çalışıldığı düşünülmektedir. Konu anlatım metninde Fransız kuvvetlerine karșı savașan Osmaniyeli Tayyar Rahmiye Hanım anlatılmakta ve bu vatansever Türk kadınının mezar taşında yazan "Yarınların sahibi ey gençlik, İyi tanı, ebedî sükûnetle bu mezarda yatanı. Hak için, bayrak için canın feda edip Armağan etti bize bu mukaddes vatanı" cümleleriyle değerin aktarılmaya çalış1ldığ düşünülmektedir. 5.sınıfta Kültürümüzü Tanıyalım başlığı altında "Kültürel ögelerin, insanların bir arada yaşamasındaki rolünü analiz eder. " kazanımı üzerinden değerin aktarılmaya çalışıldığ düşünülmektedir. Konu anlatım metninde kültürü oluşturan unsurların bizlerin bir arada yaşamasını sağladığı, inançlarımızın, ortak değerlerimizin, bayrak ve vatan sevgimizin, bayramlarımızın; kültürümüzü zenginleştirmekte ve millî birliğimizi güçlendirmekte olduğu belirtilerek değerin aktarılmaya çalışıldığg düşünülmektedir.

Üretim, Dağıtım ve Tüketim öğrenme alanında 6.sınıfta Mesleğimi Seçiyorum başlığı altında "ilgi duyduğu mesleklerin gerektirdiği kişilik özelliklerini, becerileri ve eğitim sürecini araştırır." kazanımı üzerinden değerin aktarılmaya çalışıldığı düşünülmektedir. Konu anlatım metninde Polis olmak için vatanseverlik ve polisliği sevmenin yeterli olmadığı bazı fiziksel özelliklere sahip olmak gerektiği aktarılarak değerin aktarılmaya çalışıldığı düşünülmektedir. 7.sınıfta Topraktan Üretir, Toprağ 1 Yönetiriz başlı̆̆ 1 altında "Üretimde ve yönetimde toprağın önemini geçmişten ve günümüzden örneklerle açıklar." kazanımı üzerinden değerin aktarılmaya çalışıldığı düşünülmektedir. Konu anlatım metninde Mete Han'ın “Benden eyerimi isteyin vereyim, atımı isteyin vereyim, çadırımı isteyin vereyim. Fakat hiç kimse vatanımdan bir karış toprak istemesin vermem, veremem!'” cümleleriyle değerin aktarılmaya çalışıldığı düşünülmektedir.

Etkin Vatandaşlık öğrenme alanında 4.sınıfta Özgürlük ve Bağımsızlık başlığı altında "Ülkesinin băgımsızlı̆̆ ile bireysel özgürlü̆̆̈̈ arasındaki ilişkiyi açıklar." kazanımı üzerinden değerin aktarılmaya çalışıldığı düşünülmektedir. Konu anlatım metninde vatanın bugünlere gelmesinde vatan sevgisinin, kardeşlik duygusunun ve bağımsızlık isteğinin etkili olduğu belirtilerek değerin aktarılmaya çalış1ldığı düşünülmektedir. 6.sınıfta Hayatın İçinde Demokrasi başlığı altında "Toplumsal hayatımızda demokrasinin önemini açıklar." kazanımı üzerinden değerin aktarılmaya çalışıldığ 1 düşünülmektedir. Konu anlatım metninde 15 Temmuz gecesinde Türk ordusunun içine sızmış, demokrasiyi özümsememiş terör örgütü mensuplarının tüm demokratik kuralları hiçe saydıkları, Anayasal düzeni yıkarak ayrı bir hükûmet kurmak istedikleri, Millî iradeyi yok sayarak yönetime zorla el koymaya çalıştıkları ancak Anayasa'ya göre Başkomutan olan Cumhurbaşkanı'nın çağrısına uyan halkın egemenliğine, bağımsızlığına, vatanına, bayrağına sahip çıkarak sokaklara döküldü vurgulanarak vatanseverlik değerinin aktarılmaya çalış1ldığı düşünülmektedir. 7.sınıfta Atatürk'ten Milletimize Armağan başlığı altında "Atatürk'ün Türk demokrasisinin gelişimine katkılarını açıklar." kazanımı üzerinden değerin aktarılmaya çalışıldığı düşünülmektedir. Konu anlatım metninde Atatürk'ün 1906'da ilk görev yeri olan Şam'da Vatan ve Hürriyet Cemiyetini kurduğu, bu cemiyetin adının bile Mustafa Kemal Atatürk'ün daha o yıllarda vatan sevgisi ve hürriyet aşk1 ile dolu olduğunu gösterdiği belirtilerek değerin aktarılmaya çalışıldığı düşünülmektedir. 7.sınıfta Hakimiyet Milletindir! başlı̆g 1 altında "Demokrasinin uygulanma süreçlerinde karşılaşılan sorunları analiz eder." kazanımı üzerinden değerin aktarılmaya çalışıldığı düşünülmektedir. Konu anlatım metninde ülkemizin birliğine, vatanımızın bölünmezliğine, millet egemenliğine tehdit oluşturan kalkışmanın yaşandığı 15 Temmuz'un "Demokrasi ve Millî Birlik Günü” olarak kabul edildiği belirtilerek değerin aktarılmaya çalış1ldığı düşünülmektedir. 
Vatandaş İçin Medeni Bilgiler kitapları Vatanseverlik değeri açısından incelendiğinde; kitabın 1. cildinde Millet başlığı altında Türk devleti üzerinden ve Türk Yurdu başlığı altında Türk yurdunun güzelliği üzerinden değerin aktarılmaya çalışıldığı düşünülmektedir. Kitabın 2. cildinde ise; Anayasa başlı̆g altında anayasanın tarihçesi üzerinden, Türkiye Büyük Millet Meclisi bölümünde görüşmeler üzerinden, Siyasi Fıkralar başlığı altında partiye giriş ve siyasi partilerin sakınacağı noktalar üzerinden ve Maliye bölümünde Vilayetlerde Maliye Teşkilatı başlığı altında değerin aktarılmaya çalışıldığı düşünülmektedir.

\section{Yardımseverlik Değeri}

Tablo 19: 2018 Sosyal Bilgiler Öğretim Programı ile Vatandaş İçin Medeni Bilgiler Kitabının 1. ve 2. Cildinde Yardımseverlik Değerinin Kazandırıldığı Konuların Dağılımları

\begin{tabular}{|l|l|l|l|l|}
\hline $\begin{array}{l}\text { ÖĞRENME } \\
\text { ALANLARI }\end{array}$ & SINIFLAR & $\begin{array}{l}\text { YARDIMSEVERLIK } \\
\text { DEGERININ KAZANDIRILDIĞI } \\
\text { KONULAR }\end{array}$ & $\begin{array}{l}\text { CÍLT 1 KONU } \\
\text { BAŞLIKLARI }\end{array}$ & $\begin{array}{l}\text { CÍLT 2 KOŞLIKLARI } \\
\text { BAŞLIKL }\end{array}$ \\
\hline Birey ve Toplum & 6. Sinıf & Değişen Rollerim & Hürriyet & $\begin{array}{l}\text { Sihhi ve İctimai } \\
\text { Muavenet }\end{array}$ \\
\hline Kültür ve Miras & 6. Sınıf & Yeni Yurt Anadolu & & Aile \\
\hline
\end{tabular}

Tablo 19 incelendiğinde Yardımseverlik değerinin; Birey ve Toplum ile Kültür ve Miras öğrenme alanlarında aktarılmaya çalışıldığı düşünülmektedir.

Birey ve Toplum öğrenme alanında 6.sınıfta Değişen Rollerim başlığı altında "Sosyal rollerin zaman içerisindeki değişimini inceler." kazanımı üzerinden değerin aktarılmaya çalışıldığ düşünülmektedir. Konu anlatım metninde sevinçlerimizin ve üzüntülerimizin paylaşıldığı ilk yer olan ailemiz hayatımız boyunca yer alacağımız gruplar içinde en önemlisi olduğu ve bu yüzden aile içi roller sevgi, saygı, dayanışma ve yardımseverlik duygularıyla yerine getirilmesi gerektiği belirtilerek değerin aktarılmaya çalışıldığı düşünülmektedir.

Kültür ve Miras öğrenme alanında 6.sınıfta Yeni Yurt Anadolu başlığı altında "Türklerin Anadolu'yu yurt edinme sürecini XI ve XIII. yüzyıllar kapsamında analiz eder. " kazanımı üzerinden değerin aktarılmaya çalışıldığ 1 düşünülmektedir. Konu anlatım metninde bir esnaf birliği olan Ahilerin yardımseverlikleriyle tanınmış oldukları ve Ahilerin, halkın meslek edinerek kalkınmasında ve Türk varlığının Anadolu'da kalıcı olmasında önemli rol oynadıkları belirtilerek değerin aktarılmaya çalış1ldığ düşünülmektedir.

Vatandaş İçin Medeni Bilgiler kitapları Yardımseverlik değeri açısından incelendiğinde; kitabın 1. cildinde Hürriyet bölümünde sosyal yardım üzerinden, kitabın 2. cildinde ise; Sıhhi ve İctimai Muavenet (Yardım) başlığı altında sosyal yardım üzerinden ve Aile başlığı altında ihtiyaç sahipleri üzerinden değerin aktarılmaya çalışıldığı düşünülmektedir.

\section{Vatandaş için medeni bilgiler kitabının 1. ve 2. cildinde yer verilen ancak Sosyal bilgiler} Öğretim Programında yer verilmeyen değerler hangileridir?

\section{Merhamet, Fedakârlık ve Güven Değeri}

Tablo 20: Vatandaş İçin Medeni Bilgiler Kitabının 1. ve 2. Cildinde Yer Alan Merhamet, Fedakârlık ve Güven Değerinin Kazandırıldığı Konuların Dağılımları

\begin{tabular}{|l|l|l|}
\hline DEĞERLER & CILT 1 KONU BAŞLIKLARI & CILT 2 KONU BAŞLIKLARI \\
\hline MERHAMET & Askerlik & \\
\hline \multirow{3}{*}{ FEDAKÂRLIK } & Türkiye Cumhuriyeti Nasıl Oldu \\
\cline { 2 - 2 } & Ordu Hayatı \\
\cline { 2 - 2 } & Ordu Mekteptir \\
\hline GÜVEN & Ordu Hayatı \\
\hline
\end{tabular}

Tablo 20 incelendiğinde Vatandaş İçin Medeni Bilgiler Kitabının 1. ve 2.cildinde Merhamet, Fedakârlık ve Güven değerlerinin ayrıca yer aldığı düşünülmektedir. Merhamet değerinin 1.ciltte 
Askerlik bölümünde kumandan özellikleri üzerinden aktarılmaya çalışıldığı düşünülmektedir. Fedakârlık değerinin 1.ciltte Türkiye Cumhuriyeti Nasıl Oldu başlığı altında Türk milleti üzerinden, Ordu Hayatı başlığı altında askerlik görevi üzerinden, Ordu Mekteptir başlığı altında çok yönlülük üzerinden aktarılmaya çalış1ldığı düşünülmektedir. Güven değerinin de 1.ciltte Ordu Hayatı başlığ altında ast-üst ilişkisi üzerinden aktarılmaya çalışıldığı düşünülmektedir.

\section{Sonuç ve Tartışma}

Değerler, geçmişten günümüze bizleri yönlendiren ve ne yapmamı gerektiğini öğreten temel davranışlar bütünüdür. Ancak değer aktarımlarının öğretim programlarımızda 2004 yılından sonra yer almaya başlandığ 1 görülmektedir. 2018 yılında güncellenen Sosyal Bilgiler öğretim programında 18 değere yer verilmiştir. Kuşkusuz bu durum değerlerin genç nesillere aktarılması açısından oldukça önemlidir. Çünkü değerler toplumları ayakta tutan temel dayanak noktalarındandır. Bu çalışmada Cumhuriyet döneminde örgün eğitim müfredatında yer alan ve adeta Sosyal Bilgiler ders kitabı niteliğine sahip Vatandaş İçin Medeni Bilgiler kitapları, 2018 yılında yayımlanan Sosyal Bilgiler öğretim programında yer alan 18 değere göre incelenmeye çalış1lmıştır. Elbette günümüz şartlarıyla tarihi bir eseri değerlendirmek doğru değildir. Dönemin şartlarını göz önünde bulundurarak incelenmeye çalışılan Vatandaş İçin Medeni Bilgiler kitaplarının oldukça faydalı bilgiler içerdiği bunun yanı sıra değer kavramlarına da yer verdiği düşünülmektedir.

Öğrenme alanı üzerinden yapılan inceleme sonuçlarına göre: Birey ve toplum öğrenme alanında; adalet, aile birliğine önem verme, bilimsellik, çalışkanlık, dayanışma, duyarlılık, estetik, özgürlük, saygı, sevgi, sorumluluk, vatanseverlik ve yardımseverlik değerlerinin aktarılmaya çalışıldığ 1 , bu değerler içerisinde de 5'er konu ile sevgi ve sorumluluk değerlerine daha fazla yer verildiği düşünülmektedir. Ayrıca bu öğrenme alanında bağımsızlık, barış, dürüstlük, eşitlik, tasarruf değerlerinin aktarılmadığı düşünülmektedir. Sosyal bilgiler öğretim programında bu öğrenme alanının "ben" ve "biz" olma süreçlerini içerdiği sosyal bilimlerden psikoloji, sosyoloji ve sosyal psikolojiye odaklanılmakla birlikte disiplinler arası bir yaklaşımı da benimsediği aktarılmaktadır. $\mathrm{Bu}$ bağlamda ben ve biz olma sürecinde 13 değerlerin yeterince kazandırılmaya çalışıldığı düşünülmektedir.

Kültür ve Miras öğrenme alanında; adalet, aile birliğine önem verme, barış, bilimsellik, dayanışma, duyarlılık, dürüstlük, estetik, eşitlik, özgürlük, sayg1, sevgi, vatanseverlik ve yardımseverlik değerlerinin aktarılmaya çalışıldığı, bu değerler içerisinde de 4'er konu ile adalet, aile birliğine önem verme, duyarlılık ve estetik değerlerine daha fazla yer verildiği düşünülmektedir. Bunun yanı sıra Kültür ve Miras öğrenme alanında bağımsızlık, çalışkanlık, sorumluluk, tasarruf değerlerine de yer verilmediği düşünülmektedir. Sosyal bilgiler öğretim programında bu öğrenme alanının tarih odaklı olduğu kültür ve mirası ön plana çıkaran bir yapıya sahip olduğu belirtilmektedir. Türk kültürünü oluşturan temel ögelerden hareketle kültürün korunması ve geliştirilmesini sağlayacak bir millî bilincin oluşturulmasını amaçlamaktadır. Programda da belirtilen bu özelliklerin 14 değerde yer aldığ 1 ve yeterince öğrencilere aktarılmaya çalışıldığı düşünülmektedir.

İnsanlar, Yerler ve Çevreler öğrenme alanında; dayanışma, duyarlılık, özgürlük ve tasarruf değerlerinin aktarılmaya çalışıldığı, bu değerler içerisinde 4 konu ile duyarlılık değerine daha fazla yer verildiği düşünülmektedir. Bunun yanı sıra İnsanlar, Yerler ve Çevreler öğrenme alanında; adalet, aile birliğine önem verme, bağımsızlık, barış, bilimsellik, çalışkanlık, dürüstlük, estetik, eşitlik, sayg1, sevgi, sorumluluk, vatanseverlik ve yardımseverlik değerlerine yer verilmediği düşünülmektedir. Sosyal bilgiler öğretim programında bu öğrenme alanının coğrafya odaklı olduğu belirtilmektedir. Bu öğrenme alanıyla insanın çevresi ve etkileşimini tanımak, bu konuda çeşitli beceri ve değerleri kullanarak bu etkileşimin neden ve sonuçlarını anlamak ve geleceğe yönelik bireysel ya da toplumsal bakış açısı kazandırabilmek amaçlanmaktadır. Bu çerçevede çevresel 
değişiklikler göz önüne alındığında belirtilen 4 değerin yeterince kazandırılmaya çalışıldığı düşünülmektedir.

Bilim, Teknoloji ve Toplum öğrenme alanında; adalet, bilimsellik, çalışkanlık, duyarlılık, dürüstlük, eşitlik, özgürlük ve tasarruf değerlerinin aktarılmaya çalışıldığı, bu değerler içerisinde 9 konu ile bilimsellik değerine daha fazla yer verildiği düşünülmektedir. Bunun yanı sıra Bilim, Teknoloji ve Toplum öğrenme alanında; aile birliğine önem verme, bağımsızlık, barış, dayanışma, estetik, sayg1, sevgi, sorumluluk, vatanseverlik ve yardımseverlik değerlerine yer verilmediği düşünülmektedir. Sosyal bilgiler öğretim programında bu öğrenme alanı ile öğrencilerden; bilim ve teknolojideki gelişim sürecini ve toplum yaşamı üzerindeki etkilerini kavrayarak bilgiye ulaşmada teknolojiyi kullanma becerisi edinmeleri beklenmektedir. Bununla birlikte teknolojinin günlük hayatla ilişkili olduğunu ve bazı teknolojik ürünlerin de doğaya verdiği zararları öğrenir. Programda da yer alan bilgiler ışığında 8 değerin yeterli düzeyde aktarıldığı düşünülmektedir

Üretim, Dağıtım ve Tüketim öğrenme alanında; adalet, çalışkanlık, dayanışma, duyarlılık, dürüstlük, estetik, özgürlük, sevgi, sorumluluk, tasarruf ve vatanseverlik değerlerinin aktarılmaya çalışıldığ 1 , bu değerler içerisinde 4 konu ile sorumluluk değerine daha fazla yer verildiği düşünülmektedir. Bunun yanı sıra Üretim, Dağıtım ve Tüketim öğrenme alanında; aile birliğine önem verme, bağımsızlık, barış, bilimsellik, eşitlik, saygı ve yardımseverlik değerlerine yer verilmediği düşünülmektedir. Sosyal bilgiler öğretim programında bu öğrenme alanında öğrencilerin girişimci ve bilinçli tüketici olma becerilerinin geliştirilmesi esas alınmaktadır. Öğrencilerden ülke ekonomisinde sınırlı kaynakların var olduğu, var olan kaynakların koruması gerektiğinin bilincinde olmaları, kendi ekonomik yaşantıları ile başkalarının yaşantılarını karşılaștırarak farklılıkları ve benzerlikleri ortaya koymaları, yaşadıkları bölgenin ekonomik koşullarını inceleyip bu koşulları geliştirmek için çaba göstermeleri beklenmektedir. Bu beklentiler göz önüne alındığında 11 değerin yeterli düzeyde aktarıldığı düşünülmektedir.

Etkin Vatandaşlık öğrenme alanında; adalet, bağımsızlık, barış, dayanışma, duyarlılık, eşitlik, özgürlük, saygı, sevgi, sorumluluk ve vatanseverlik değerlerinin aktarılmaya çalışıldığı, bu değerler içerisinde 8'er konu ile eşitlik ve özgürlük değerlerine daha fazla yer verildiği düşünülmektedir. Etkin Vatandaşlık öğrenme alanında; aile birliğine önem verme, bilimsellik, çalışkanlık, dürüstlük, estetik, tasarruf ve yardımseverlik değerlerine de yer verilmediği düşünülmektedir. Etkin Vatandaşlık öğrenme alanında sosyoloji, siyaset bilimi ve hukuk çerçevesinde etkin vatandaşlık kavramları üzerinde durulmaktadır. Sosyal bilgiler dersini alan öğrenciler bu öğrenme alanı içerisinde toplumsal sorunların nasıl çözüldüğünü ve düzenin nasıl sağlandığını anlayarak egemenliğin kaynağının millete dayandığı yönetimlerde, birey haklarının ve toplum düzeninin nasıl korunduğunu fark ederler. İncelenen program ve ders kitapları çerçevesinde 11 değerin yeterli düzeyde aktarıldığı düşünülmektedir.

Küresel Bağlantılar öğrenme alanında; barış, çalışkanlık, duyarlılık ve saygı, değerlerinin aktarılmaya çalışıldığ düşünülmektedir. Günümüzdeki inançların, fikirlerin, insanların, sermayelerin, bilgilerin, teknolojilerin, kültürel ve siyasi sinırları aştığı küresel boyutta hareket hâlinde oldukları görülmektedir. Bu dönem içerisinde devletlerinde de kendisi dışındakilerle bir yandan iş birliği yaparken diğer taraftan rekabet etmeleri gerekmektedir. Küresel Bağlantılar öğrenme alanı yardımıyla dünyanın gündemini takip eden, karşılaştı̆̆ı sorunlara çözüm üretebilen etkin ve sorumlu Türk vatandaşları yetiştirmek temel gayedir. Bu doğrultuda 4 değerin yeterli düzeyde aktarıldığı düşünülmektedir.

Sınıf bazında yapılan inceleme sonuçlarına göre: 4.sınıfta; adalet, aile birliğine önem verme, bağımsızlık, barış, bilimsellik, dayanışma, duyarlılık, dürüstlük, eşitlik, özgürlük, sayg1, sevgi, sorumluluk, tasarruf ve vatanseverlik değerlerine yer verildiği düşünülmektedir. Çalışkanlık, estetik ve yardımseverlik değerlerine ise yer verilmediği düşünülmektedir. 5.sınıfta; adalet, aile birliğine 
önem verme, bağımsızlık, bilimsellik, çalışkanlık, dayanışma, duyarlılık, dürüstlük, estetik, eşitlik, özgürlük, saygı, sevgi, sorumluluk ve vatanseverlik değerlerine yer verildiği düşünülmektedir. Barış, tasarruf ve yardımseverlik değerlerine ise yer verilmediği düşünülmektedir. 6.sınıfta; adalet, aile birliğine önem verme, barış, bilimsellik, çalışkanlık, dayanışma, duyarlılık, dürüstlük, estetik, eşitlik, özgürlük, sayg1, sevgi, sorumluluk, tasarruf, vatanseverlik ve yardımseverlik değerlerine yer verildiği düşünülmektedir. Bağımsızlık değerine ise yer verilmediği düşünülmektedir. 7.sınıfta ise; adalet, barış, bilimsellik, çalışkanlık, dayanışma, duyarlılık, dürüstlük, estetik, eşitlik, özgürlük, saygı, sevgi, sorumluluk ve vatanseverlik değerlerine yer verildiği düşünülmektedir. Aile birliğine önem verme, bağımsızlık, tasarruf ve yardımseverlik değerlerine ise yer verilmediği düşünülmektedir. Bu sonuçlar doğrultusunda en fazla değer aktarılan sınıfın 17 değer ile 6.sınıf, en az değerin ise 14 değer ile 7.sınıf düzeyinde kazandırılmaya çalışıldığı düşünülmektedir.

Vatandaş için medeni bilgiler kitaplarının 1. ve 2.ciltleri değerler üzerinden incelenmiş ve sonuç olarak: 1. ciltte; adalet, bağımsızlık, barış, bilimsellik, çalışkanlık, dayanışma, dürüstlük, estetik, eşitlik, özgürlük, sayg1, sevgi, sorumluluk, tasarruf, vatanseverlik ve yardımseverlik değerlerine yer verildiği düşünülmektedir. Aile birliğine önem verme ve duyarlılık değelerine ise yer verilmediği düşünülmektedir. 2.ciltte ise; adalet, aile birliğine önem verme, bağımsızlık, barış, bilimsellik, çalışkanlık, dayanışma, duyarlılık, dürüstlük, estetik, saygı, sevgi, sorumluluk, tasarruf, vatanseverlik ve yardımseverlik değerlerine yer verildiği düşünülmektedir. Eşitlik ve özgürlük değerlerine ise yer verilmediği düşünülmektedir. Bununla birlikte 1.ciltte Merhamet, Fedakârlık ve Güven değerlerine yer verilmiştir.

Sonuç olarak; hem sosyal bilgiler öğretim programı ve ders kitapları hem de vatandaş için medeni bilgiler kitaplarının değer aktarımı konusunda yeterli düzeyde oldukları düşünülmektedir. Değer aktarım konuları açısından sosyal bilgiler programı ve ders kitaplarında yer alan konu içerikleri ile medeni bilgiler kitaplarının değer aktarım açısından örtüştüğü söylenilebilir.

2018 Sosyal bilgiler öğretim programı metninin içerik olarak ders kitaplarına uygunluğu ve değer tanıtımı açısından tekrar gözden geçirilmesi önerilmektedir.

\section{Kaynakça}

Aristoteles (2014), Nikomakhos'a Etik. (Furkan Akderin çev), İstanbul, Say Yayınları.

Baş, K., Taşkıran, C., Bulut, B. (2016). Sosyal Bilgiler Öğretmenlerinin Değerler Eğitimine Yönelik Görüssleri. Uluslararası Türk Eğitim Bilimleri Dergisi, 2016 (6), 75-84. Retrieved from https://dergipark.org.tr/tr/pub/goputeb/issue/34311/379174, "https://doi.org/10.24106/kefdergi.3594"

Bayramoğlu, E. O. (2016). Öğretmenlerin Demokratik Değerleri İle İş Doyumları Arasındaki İlişkinin İncelenmesi. Yayınlanmamış Yüksek Lisans Tezi, Sosyal Bilimler Enstitüsü, Kafkas Üniversitesi, Kars, "https://doi.org/10.9775/kausbed.2017.024"

Beldağ, A., Özdemir, Ü., Nalçacı, A. (2017). Sosyal Bilgiler Dersi Öğretim Programında Yer Alan Değerlerin Kazandırılmasına İlişkin Veli Görüşleri. Kırıkkale Üniversitesi Sosyal Bilimler Dergisi, 7 (2), 317-328, "https://doi.org/10.21764/maeuefd.312152"

Berkowitz, M., \& Bier, M. (2006). What works in character education: A research-driven guide for educators. Washington, DC: Character Education Partnership.

Büyükkaragöz, S. ve Çivi, C. (1999). Genel Öğretim Metotları Öğretimde Planlama Uygulama, Beta Yayınc1lik, İstanbul. 
Coombs-Richardson, Rita \& Tolson, Homer. (2005). "A Comparison Of Values Rankings For Selected American And Australian Teachers." Joumal of Research in International Education, 4, 263-277, "https://doi.org/10.1177/1475240905057805"

Çırak, A. (2019). Demokratik Değerler, Demokratik Eğitim ve Sosyal Bilgiler Eğitimi İlişkisi. Uluslararası Güncel Eğitim Araştırmaları Dergisi, 5 (1), 1-18. Retrieved from https://dergipark.org.tr/tr/pub/intjces/issue/49055/625855, "https://doi.org/10.20860/ijoses.435764"

Ekşi, H. (2003). "Temel İnsani Değerlerin Kazandırılmasında bir Yaklaşım: Karakter Eğitimi Programları". Değerler Eğitimi Dergisi, Cit:1, Sayı:1, 79-96, "https://doi.org/10.14527/9786052419939.01"

Fernandes, L. (1999). Value personalisation: A base for value education. www.eric.ed.gov, ERİC Document: ED 434880.

Gültekin, G. vd. (2018). Ortaokul ve İmam Hatip Ortaokulu Sosyal Bilgiler 7 Ders Kitab1. MEB Devlet Kitapları Birinci Bask1. Ankara. ISBN 978-975-11-4680-9

Güngör, E. (1998). Ahlak Psikolojisi ve Sosyal Ahlak, Ötüken Yayınevi, İstanbul.

Gürses, F. (2010), “Kemalizm'in Model Ders Kitabı: Vatandaş İçin Medeni Bilgiler”, Akademik Bakış, Cilt 4, Sayı:7, 233-349

Harris, E. L. (1991). Identifying İntegrated Values Education Approaches İn Secondary Schools. $\mathrm{PhD}$ Thesis, Office of Graduate Studies of Texas A \& M University, Texas, USA.

İbret, B. Ü., Karatekin, K., Avcı, E. (2015). Sosyal Bilgiler Dersinde Coğrafya Öğretiminin Değerler Eğitimi Açısından Önemi. Milli Eğitim Dergisi, 45 (207), 5-23, "https://doi.org/10.17556/erziefd.478416"

İnan, A. A. (1933). Vatandaş İçin Medeni Bilgiler (Cilt 1), İstanbul Devlet Matbaası, İstanbul.

Kaşkaya, A ve Duran, T. (2017). İlkokul Türkçe Ders Kitaplarının Değer Aktarımı Açısından İncelenmesi. Trakya Üniversitesi Eğitim Fakültesi Dergisi, Cilt 7, Sayı 2, 417-441, "https://doi.org/10.24315/trkefd.303978"

Kirschenbaum, H. (1995). Enhance values and morality in schools and youth settings, Massachusetts: Allyn\&Bacon Company.

M.E.B. (2018), 2018 Sosyal Bilgiler Dersi Öğretim Programı (İlkokul ve Ortaokul 4, 5, 6 ve 7. Siniflar), Ankara, "https://doi.org/10.22464/diyalektolog.257"

Nalçacı, A. (2016). Değer Kazandırmada Örnek Olay İnceleme Yöntemi, Refik Turan ve Kadir Ulusoy (Ed.). Faklı yönleriyle değerler eğitimi içinde (ss.324-338). Pegem Akademi Yayınc1l1k, Ankara, "https://doi.org/10.14527/9786053648222.14"

Özankaya, Ö. (2002). "Yurttaş İçin Medeni Bilgiler ya da Çok-Partili Dönemde Rafa Kaldırılan Demokrasi Dersleri”, Mülkiye Dergisi, Cilt: XXVI, Sayı:233, 93-99.

Peker, R. (1931). Vatandaş İçin Medeni Bilgiler (Cilt 2), İstanbul Devlet Matbaası, İstanbul.

Ryan, K. ve Bohlin, K. E. (1999). Building character in schools. California: Jossey-Bass İnc.

Sağnak, M. (2004). Ortaöğretim Okullarında Öğrenim Gören Öğrencilerin Okulun Örgütsel Değerlerine İlişkin Algıları ile Kişisel Değerleri Arasındaki Uyum Düzeyleri. Değerler ve Eğitimi Uluslararası Sempozyumu. 
Seydi, A. (2015). İlköğretim 5. 6. 7. Sınıf Sosyal Bilgiler Öğretmen Kılavuz Kitaplarında Değerler Eğitiminin Ele Alınışı. SDU International Journal of Educational Studies, 1 (2), 63-79. Retrieved from https://dergipark.org.tr/tr/pub/sduijes/issue/20862/223845

Şahin, E. (2018). Ortaokul ve İmam Hatip Ortaokulu Sosyal Bilgiler 5 Ders Kitabı. Anadol Yayınc1lı, Ankara. ISBN: 978-605-65078-2-3

Tatto, M. T. vd. (2001). Examining Mexico's Values Education in a Globally Dynamic Context, Journal of Moral Education, 30:2, 173-198, "https://doi.org/10.1080/03057240120061405"

Tüysüz, S. (2019) ilkokul Sosyal Bilgiler 4 Ders Kitabı. Tuna Matbaacılık, Ankara. ISBN: 978-9758198-80-1

Ulusoy, K. (2007). Lise Tarih Programında Yer Alan Geleneksel ve Demokratik Değerlere Yönelik Öğrenci Tutumlarının ve Görüşlerinin Çeşitli Değisskenler Açısından Değerlendirilmesi. Yayınlanmamış Doktora Tezi, Eğitim Bilimleri Enstitüsü, Gazi Üniversitesi, Ankara, "https://doi.org/10.17152/gefad.540943"

Vaillant, G. E., \& Vaillant, C. O. (1981). Natural history of male psychological health: X. Work as a predictor of positive mental health. The American journal of psychiatry, 138(11), 14331440, "https://doi.org/10.1176/ajp.138.11.1433"

Veugelers, W. \& Vedder P. (2003). (2003) Values in teaching, Teachers and Teaching, 9:4, 377-389, DOI: 10.1080/1354060032000097262, “https://doi.org/10.1080/1354060032000097262"

Veugelers, W., \& Vedder, P. (2003). Values in teaching. Teachers and Teaching: Theory and Practice, 9, 377-389, "https://doi.org/10.1080/1354060032000097262"

Yıldırım, A. ve Şimşek, H. (2008). Sosyal Bilimlerde Nitel Araştırma Yöntemleri. Ankara: Seçkin Yayınevi.

Yıldırım, A. ve Şimşek, H. (2011). Sosyal Bilimlerde Nitel Araştırma Yöntemleri (8th ed.). Ankara: Seçkin Yayınevi.

Yılmaz, F. G. vd. (2018). Ortaokul ve İmam Hatip Ortaokulu Sosyal Bilgiler 6 Ders Kitabı. MEB Devlet Kitapları Birinci Bask1. Ankara. ISBN 978-975-11-4684-7 